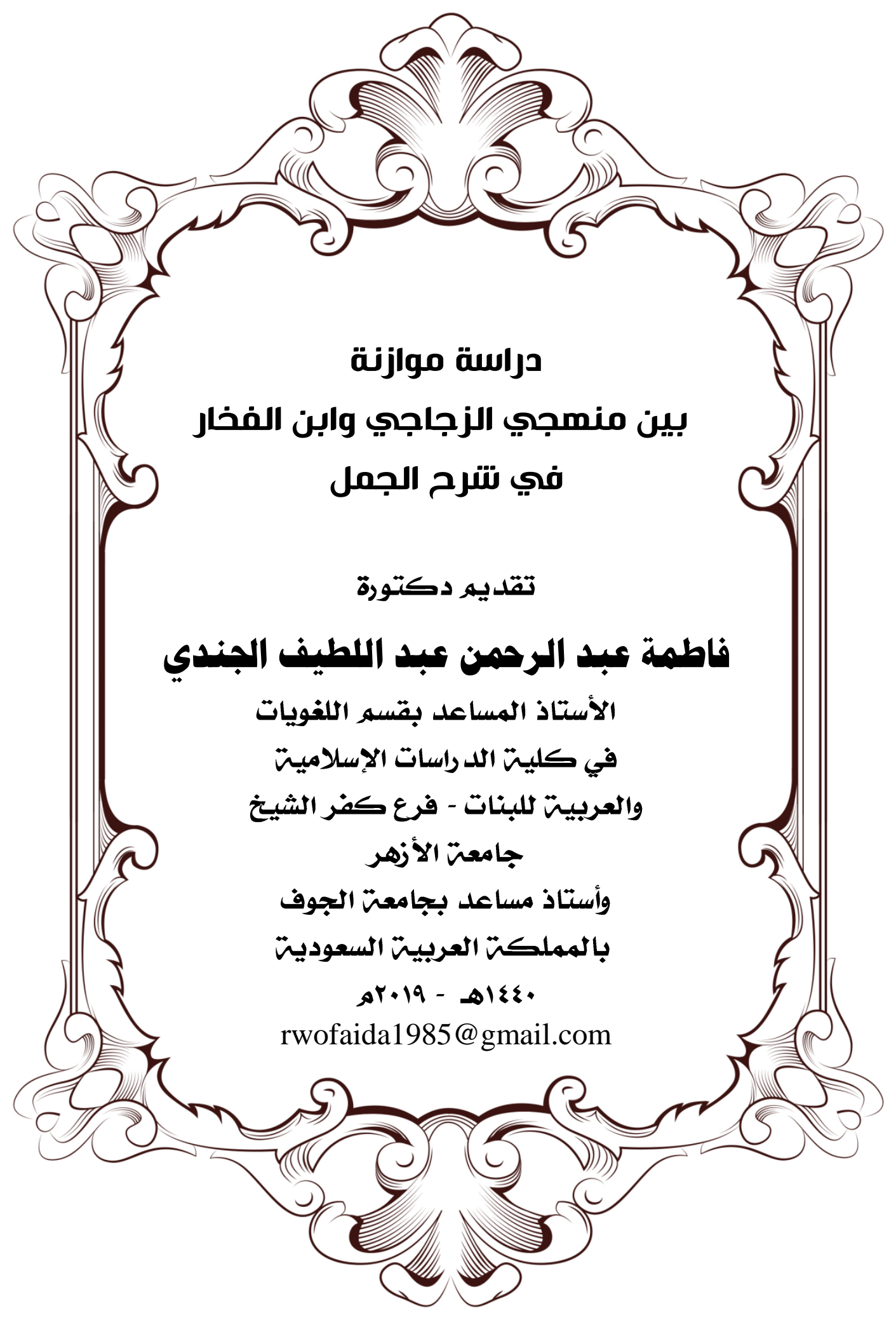



حوليت كليت اللغت العربيت بإيتاى البارود (العدد الثاني والثلاثون - المجلد الرابع)

\section{ملخص بحث}

\section{(دراست موازنت بين منهجي الزجاجي وابن الفخار في شرح الجمل)}

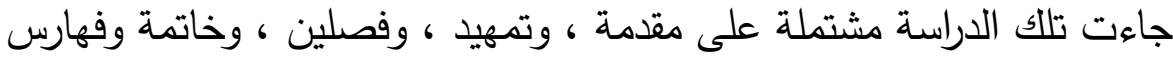
فنية متتوعة .

أما المقدمة فتحدثت فيها عن أهمية اللغة العربية ، وأما التمهيد فتحدثت فيه بايجاز عن كتابي (الجمل) و (شرح الجمل) وصاحبيهما ، ومعنى الموازنة ،

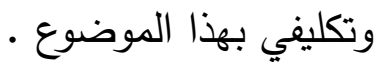

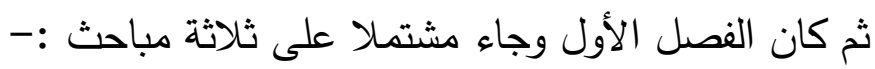
المبحث الأول في: ترجمة الزجاجي وتشمل: (اسمه وكنيته ، نسبه ، لقبه ، مولده ، نشأته، وتنقلاته ، صفاته وأخلاقه ، شيوخه ، تلاميذه ، ثقافته ، مذهبه النحوي، مؤلفاته وآثاره، وفاته) . المبحث الثاني في : التعريف بكتاب (الجمل) للزجاجي ويشمل : ( موضوع الكتاب ، متته ، أسلوبه ، منهجه ، قيمته ، شروحه ، المحققين له ) . المبحث الثالث في : ترجمـة ابن الفخـار وتشـمل : ( اسـمه ونسبه وشـهرته

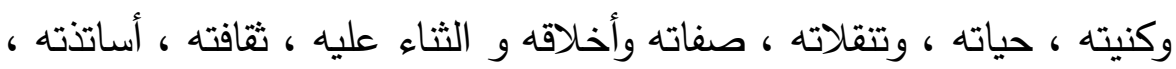
تلاميذه ، آثاره ومؤلفاته ، وفاته ، عصره ) . ثم كان الفصل الثاني وتحدثت فيه عن : منهج ابن الفخار ( في شرح الجمل) دراسـة موازنـة وجاء هذا الفصل مشتملا على أوجه الموازنة بين الزجاجي في

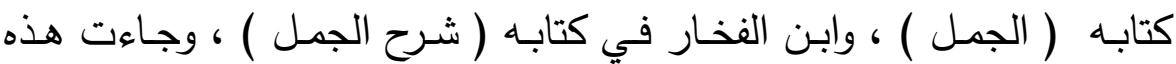
الأوجه متمثلة في خمسة عشر وجها هي :أولاً : من حيث بداية تأليف الكتابين .

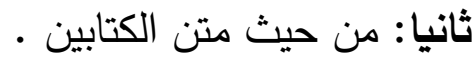

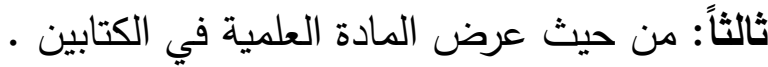
رابعاً : من حيث ما يترتب على المسائل النحوية والصرفية من أمور غيرهما

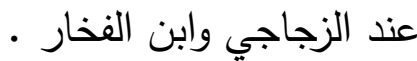




\section{دراسة موازنة بين منسجي الزجاجي وابن الفخار في تترح الجمل}

حوليت كليت اللغت العربيت بإيتاى البارود (العدد الثاني والثلاثون - المجلد الرابع) خامساً : من حيث التعريفات والحدود عند الزجاجي وابن الفخار • سادسـا : من حيث التفصيل في مسائل الخلاف النحوي عند الزجاجي وابن الفخار سابعا : من حيث التعليلات عند الزجاجي وابن الفخار • ثامنا: من حيث الاختيارات عند الزجاجي وابن الفخار • تاسعا : من حيث المخالفات لبعض النحاة عند الزجاجي وابن الفخار • عاشرا : من حيث أسلوب الزجاجي وابن الفخار • حـادي عثـر : مـن حيث الحكايـات التي وقعـت للزجـاجي وابـن الفخـار أو حضرها كل منهما.

ثاني عشر : من حيث الشواهد عند الزجاجي وابن الفخار • ثالث عشر : من حيث المذهب النحوي ، وموقف الزجاجي وابن الفخار من • البصرين والكوفيين

رابع عشر : من حيث اعتماد الزجاجي وابن الفخار على المصادر • خامس عشر : من حيث موقف الزجاجي وابن الفخار من السماع والقياس . ثم تحدثت بعد ذلك عن [موقف ابن الفخار من الزجاجي (اعتراض ودفاع )]. ثم تحدثت بعد ذلـك عن : مواطن الاتفاق والاختلاف بين الزجاجي وابن الفخار ، ووضعتها تعت عنوان : ( اتفاق وافتراق ) . ثم كانـت الخاتمـة ، وتحدثت فيها عن أبرز النتائج التي توصلت إليها من

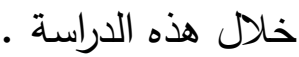
وأخيرا كانت الفهارس الفنية المتنوعة

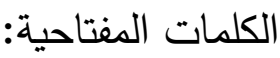
موازنة- الزجاجي- ابن الفخار - الجمل - شرح الجمل. 
حوليت كليت اللغت العربيت بإيتاى البارود (العدد الثاني والثلاثون - المجلد الرابع)

\section{Research Summary}

(A study of the balance between the glass and Ibn al-Fakhar methodologies in explaining sentences)

The study included an introduction, introduction, two chapters, a conclusion and various artistic indexes.

As for the introduction, I talked about the importance of the Arabic language.

Then the first chapter came and included three topics- :

The first topic in the translation of the glass includes: (name and nickname, lineage, title, birth, birth, and mobility, qualities and morals, elders, his disciples, his culture, his grammar, his writings and effects, and his death.)

The second topic in: Definition of the book (sentences) for the glass and includes: (the subject of the book, board, style, methodology, value, explanations, investigators.)

The third topic in the translation of Ibn al-Fakhar includes: (His name, proportions, fame and nickname, his life, his mobility, his qualities and morals and praise it, his culture, his teachers, his disciples, his effects and his works, his death, his age.)

Then was the second chapter and talked about: Ibn alFakhar method (in explaining sentences) balancing study This chapter included the aspects of balancing between glass in his book (sentences), and Ibn al-Fakhar in his book (explaining sentences), and these aspects came in fifteen faces she-:

First, in terms of the beginning of the two books.

Second: in terms of the body of the two books.

Third: In terms of the presentation of scientific material in the two books.

Fourth: In terms of the implications of grammatical and morphological issues from other matters at the glass and Ibn al-Fakhar.

Fifth: in terms of tariffs and borders when glassy and pottery. 
حوليت كليت اللغت العربيت بإيتاى البارود (العدد الثاني والثلاثون - المجلد الرابع)

Sixth: In detail in the issues of grammatical disagreement when the glass and the pottery

Seventh: in terms of explanations when the glass and pottery.

Eighth: in terms of choices when the glass and pottery.

Ninth: In terms of irregularities to some of the grammars when the glass and the pottery.

Tenth: in terms of glassy style and pottery son.

Eleventh: In terms of the tales that occurred to the glass and the son of pottery or attended by each.

Twelfth: In terms of evidence at the glass and the pottery.

Thirteenth: in terms of grammatical doctrine, the position of the glass and the pottery son of the visuals and Kufites.

Fourteenth: in terms of the dependence of the glass and the son of pottery on the sources.

Fifteenth: in terms of the position of the glass and the pottery son of hearing and measurement.

Then I talked about [the position of the pottery son of glass (objection and defense.[(

Then I talked about: the areas of agreement and the difference between the glass and Ibn al-Fakhar, and put it under the title: (agreement and separation.(

Then it was the conclusion, and talked about the main findings of this study.

Finally the artistic indexes were diverse

key words:

Balancing - glass - son pottery - sentences - explain the sentences. 


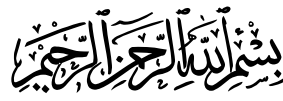

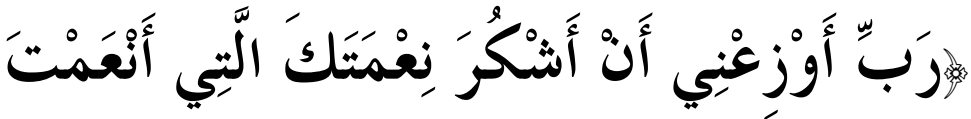

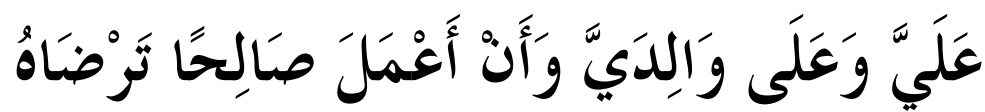

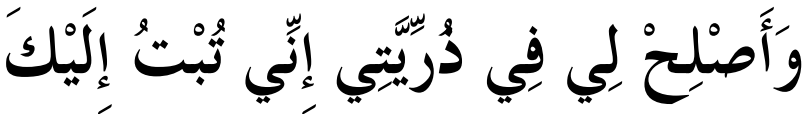

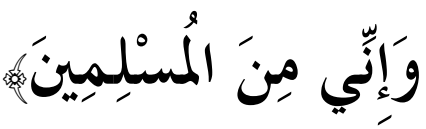

صدق الله العظيه

. $\{10:$ : الأحقاف 
حوليت كليت اللغت العربيت بإيتاى البارود (العدد الثاني والثلاثون - المجلد الرابع)

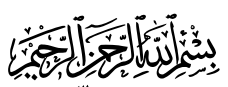

ina

الحمد لله ذي المنن الجزيلةة، والعطايـا الجليلة، التي لا ينقطع أمدها،

ولا تـدرك نهايتهـا، سـبحانك كاثـف الغطـاء، ومـانح العطـاء، ذي الجـود

والإيداء، (') والإعادة و الإبداء، والصلاة والسلام على حبيبي وقرة عيني محه -

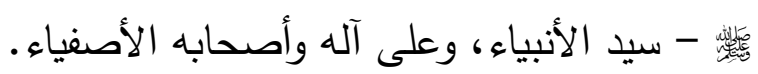

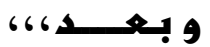

فإن اللغة العربية صورة من حياة أصحابها - ترقى برقيهم، وتتخلف وفت

بتخلفهم، وحين كان العرب متقدمين بالإسـلام تقدمت بهم لغتهم، فحين تخلفوا عنه تخلفت بهم أيضاً. ذلك أن قدر هذه العربية أنها وعاء الإسـلام الحنيف، شئنا ذلك أو أبينا، هكذا كانت في غابر الزمن وهكذا تكون إلى الأبد. لقد دفع الإسلام بالعربية إلى ارتياد آفاق العلم التجريبي، حتى صسارت لغة العلم كما هي لغة الدين والأدب، ولم يطرأ على العربية شيء يخلع عنها هذا الثوب الذي كساها به الإسلام، فهي لغة صالحة لتكون لغة العالمين.

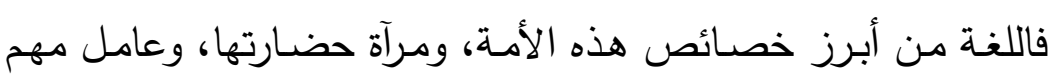
مـن عوامل وحدتها، وكل أمسة تعتز بشخصيتها وتفخر بذاتها تهتم بلغتها، وتحافظ عليها محافظتها لأبنائها.

وللغة العربية بشكل خاص في أفئدة معظم الناطقين بها منزلة أسمى مدا لغيرهـا، فهي لغـة القرآن الوحي الإلهي الذي كرّم الله - عز وجل - بـه

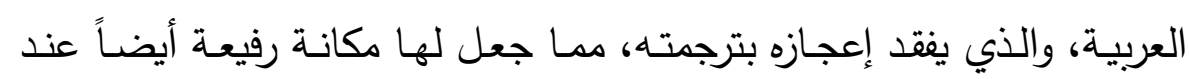
أجناس متفرقة مسلمة غير عربية.

(1) الإيداء: المعونة من آدي فلان إيداء: قوي، وآداه على كذا: قواه عليه وأعانه.

ينظر : لسان العرب لابن منظور (آد). 


\section{دراسة موازنة بين منسجي الزجاجي وابن الفخار في تترح الجمل}

حوليت كليت اللغت العربيت بايتاى البارود (العدد الثاني والثلاثون - المجلد الرابع)

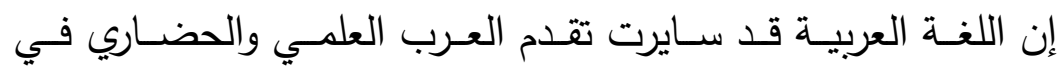

الماضـي، وكانت لفترة من الزمن لغـة العلوم في جميع أنحـاء العـالم، وكان

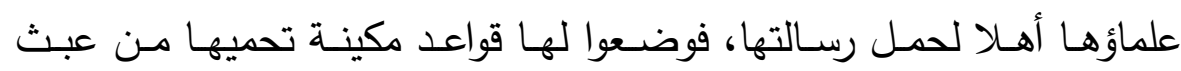
العابثين، وتكفل تقدمها وتطورها.

ولقد كتب الأقدمون في كل علوم العربية، وأبدعوا، وستبقى كتبهر

نافذة يطل منها أبناء هذا العصر على ماضي أمتهم الزاهر ، كما ستبقى نقطة ولته الانطلاق نحو إحياء اللغة وتطويرها، وتجديد مناهجها.

- 
حوليت كليت اللغت العربيت بإيتاى البارود (العدد الثاني والثلاثون - المجلد الرابع)

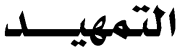

الحمد لله رب العالمين، المنزل كتابه بلسـان عربي مبين، والصـلاة والسـلام

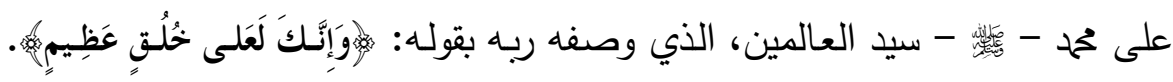
\}القلم: §\{. وعلى آله وأصـحابه الطبيين الطساهرين، ومـن تبعهم بإحسـان إلى يوم الدين.

\section{وبـد: -}

فإن كتاب (الجمل) قد وضـعه إمام من أئمسة اللغة والنحو في القرن الرابع الهجري هو الإمـام أبو القاسـ الزجاجي، وقد كان هذا القرن قد بلغت فيه الثقافـة الإسلامية مبلغا رائعاً من الخصب والشمول، وضرب الفكر الإسـلامي فيه مثلاً رائعاً

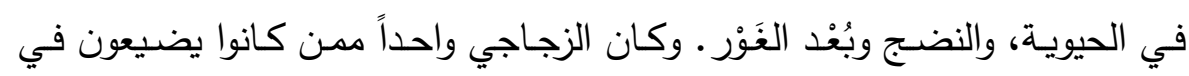
غمرة الدوى العظيم الذي خلّفه أمثال أبي على الفارسي المتوفى سنة VY Vه، وتلميذه الفذّ أبي الفتح بن جنى المتوفى سنة بوه الهـ. لقد كان الزجاجي من أكثر علماء عصره حيوية ونشاطا في ميادين النحو واللغة والأدب، بل هو صساحب الصوت المدوّى قبل أن يغلب على الأسماع صوت الفارسي وابن جنى، وإذا كتابه (الجمل) مطبق بلاد المسلمين مشرقها ومغربها شـهرة وانتشـارا، حتى كـان لـه في بـلاد المغرب وحدها مئسة وعشـرون شـرحا، وكان هـو

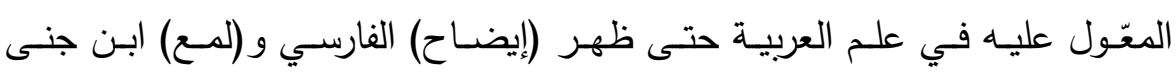
فأخملاه.

وكان منهج الزجاجي في كتابـه (الجمل) قائم على تجنب الجدل النظري

والتعليل الفلسفي بـل يعني بتقريب النحو إلى أفهام الناس عامـة، وأفهام المبتدئين خاصة، وكان قبل ذلك كله يمثل حلقه من حلقات تاريخنا النحوي. وهذا الكتاب قد ألفت حوله الكثير من الكتب، منها الثـروح، ومنها في مني حنه شروح الشواهد ومنها في التعقيب عليه أو التعليق ومن شروحه: (شرح الجمل) لابن الفخار (ححمد بن على بن أحمد بن حمحد بن هذيل الخولاني إلا لبيرى أبو عبد الله). ورغبة في إحياء سيرة الزجاجي، وإماطة اللثام عن كتاب (الجمل)، وكذلك موازنـة (الجمـل) بغيـره مـن شـروحه وهـو (شـرح الجمـل) لابـن الفخـار ، كانـت تلك الدراسة التي كلفت بها. 


\section{دراسة موازنة بين منسجي الزجاجي وابن الفخار في تترح الجمل}

حوليت كليت اللغت العربيت بإيتاى البارود (العدد الثاني والثلاثون - المجلد الرابع) لقد كان ابن الفخار من علماء القرن الثامن الهجري المتميزين الذين أسهوبا في دراسة النحو بجهود كبيرة كان من نتاجها كتابه هذا (شرح الجمل). وابن الفخار

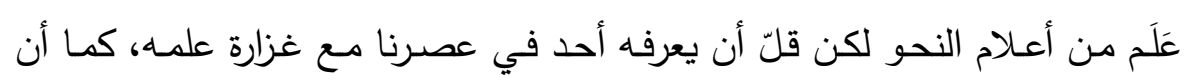

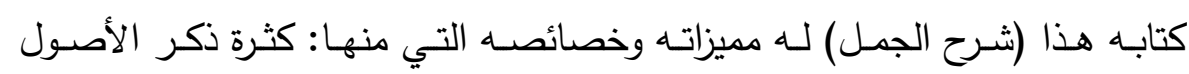

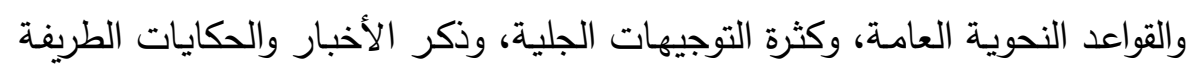
التي تخلو منها الكثير من كتب النحو، هذا بالإضافة إلى شذوذه عن نسق التآليف

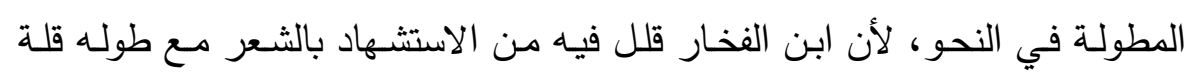
ملفته للنظر . ملن

وإذا كانت الموازنـة تعنـي: المقارنـة بين كل عنصرين اجتمع لهما التشـابه المطلق أو التقارب النسبي في الصفات العامـة، كما أنها تطلعنـا على معرفة أوجها

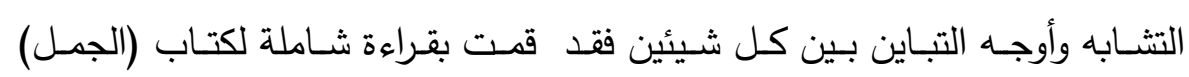
للزجاجي، وكتاب (شرح الجمل) لابن الفخار، بل قراءات عديدة حتى أستطيع القيام

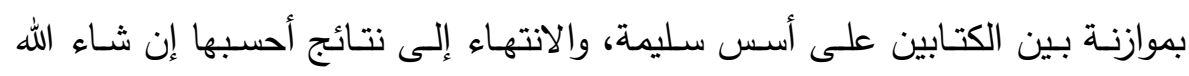
صائبة.

هذا وقد اعتمدت في هذه الدراسـة على نسـخة مـن (شـرح الجمل) لابـن الفخار بعد بحث طويل، هي رسالة دكتوراه تحت عنوان: (أبو عبد الله بن الفخار

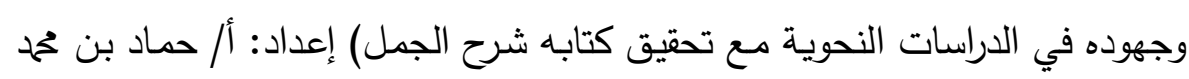

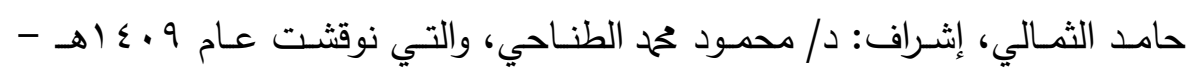

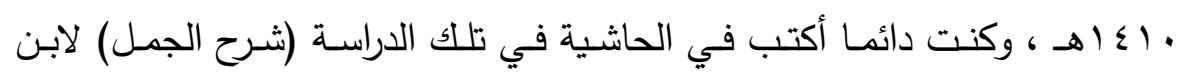
الفخار اختصارا.

هذا وقد جاءت تلك الدراسة مشتملة على مقدمة، وتمهيد، وفصلين، وخاتمة وفهارس فنية متنوعة.

أمسا الاقدهـهـة فتحدثت فيها عن أهمية اللغـة العربية، وأمـا التمهيد فتحدثت فيه بإيجاز عن كتابي (الجمل) و (شرح الجمل) وصاحبيهما، ومعنى الموازنة، وتكليفي بهذا الموضوع. بإنجان. ثم كان الفصل الأول وجاء مشتملا على ثلاثة مباحث:- 
حوليت كليت اللغت العربيت بإيتاى البارود (العدد الثاني والثلاثون - المجلد الرابع) المبحسث الأول في: ترجمـة الزجاجي وتشمل: (اسـمه وكنيته، نسبه، لقبه، مولده، نشأته، وتتقلاته، صفاته وأخلاقه، شيوخه، تلاميذه، ثقافته، مذهبه

$$
\text { النحوي، مؤلفاته وآثاره، وفاته). }
$$

المبحـث الثـاني في: التعريف بكتاب (الجمل) للزجاجي ويشمل: (موضوع الكتاب، متته، أسلوبه، منهجه، قيمته، شروحه، المحققين له). المبـحسث الثادث في: ترجمـة ابن الفخار وتشـمل: (اسـمه ونسبه وشـهرته وكنيته، حياته، وتتقلاته، صفاته وأخلاقه و الثناء عليه، ثقافته، أسـاتذته،

$$
\text { تلاميذه، آثاره ومؤلفاته، وفاته، عصره). }
$$

\section{ثم كان الفمسل الثـاني وتحدثت فيه عن: منهج ابن الفخار (في}

شرح الجمل) دراسـة موازنـة وجاء هذا الفصل مشتملا على أوجه الموازنـة بين الزجاجي في كتابه (الجمل)، وابن الفخار في كتابه (شرح الجمل)، وجاءت هذه الأوجه متمثلة في خمسة عشر وجها هي:أولاً: من حيث بداية تأليف الكتابين. ثانيًا: من حيث متن الكتابين. ثالثًا: من حيث عرض المادة العلمية في الكتابين. رابعًا: من حيث ما يترتب على المسائل النحوية والصرفية من أمور غيرهما عند الزجاجي وابن الفخار •

خامسًا : من حيث التعريفات والحدود عند الزجاجي وابن الفخار . سادسًا: مـن حيث التفصيل في مسـائل الخـلاف النحوي عند الزجاجي وابن الفخار

سابعًا: من حيث التعليلات عند الزجاجي وابن الفخار • ثامنا: من حيث الاختيارات عند الزجاجي وابن الفخار • تاسعا: من حيث المخالفات لبعض النحاة عند الزجاجي وابن الفخار . عاشرا: من حيث أسلوب الزجاجي وابن الفخار • 

حادي عشر: من حيث الحكايات التي وقعت للزجاجي وابن الفخار أو حضرها كل من من

ثاني عشر: من حيث الثواهد عند الزجاجي وابن الفخار. ثالث عشر: من حيث المذهب النحوي، وموقف الزجاجي وابن الفخار من البصرين والكوفين.

رابع عشر: من حيث اعتماد الزجاجي وابن الفخار على المصادر • خامس عشر: من حيث موقف الزجاجي وابن الفخار من السماع والقياس. ثم تحدثت بعد ذلك عن [موقف ابن الفخار من الزجاجي (اعتراض ودفاع)]. ثـم تحدثت بعـد ذلــ عـن: مـواطن الاتفـاق والاختلاف بين الزجاجي وابن الفخار، ووضعتها تحت عنوان: (اتماق وافتراق). ثم كانت الخاتمهـة، وتحدثت فيها عن أبرز النتائج التي توصلت إليها من خلال هذه الدراسة. وأخيرا كانت الفهـارس الفنهـة المتتوعة وهي فهرس القرآن الكريم، وفهرس الحديث النبوي الشريف، وفهرس الثواهد الشعرية، وفهرس المراجع والمصادر وفهرس الموضوعات.

هذا وأدعو الله أن أكون قد وفقت في تلك الدراسـة، وإن كان هنـاك شيء من السهو أو التقصير فمن نفسي والثيطان. و الله أسأل أن يرزقنا السداد في القول، والإخلاص في الفكر والعمل.

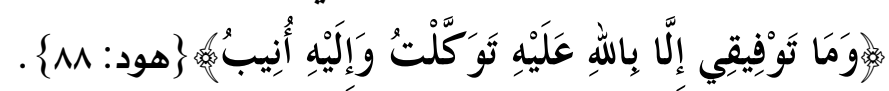

$$
\text { الباحثن }
$$

دكتورة / فاطمن عبد الرحمن عبل اللطيف الجندي الأستاذ المساعد بقسهر اللغويات في كلين اللد راسات الإسلاميت والعربيته للبنات - فرع كفر الشيخ - جامعت الأزهر. 
دراسة موازنة بين منسجي الزجاجي وابن الفخار في تترح الجمل

حوليت كليت اللغت العربيت بإيتاى البارود (العدد الثاني والثلاثون - المجلد الرابع)

\section{الفصل الأول}

ويشتمل على ثلاثة مباحث:

المبحـث الأول فـي: ترجمـة الزجـاجي وتشـمل: (اسـمه وكنيته، نسـبه، لقبه، مولده، نشأته وتتقلاته، صفاته وأخلاقه، شيوخه، تلاميذه،

ثقافته، مذهبه النحوي، مؤلفاته وآثاره، وفاته).

المبحـث الثـاني في: التعربف بكتـاب "الجمـل" للزجـاجي ويشـمل: (موضـوع

الكتاب، متتـه، أسلوبه، منهجه، قيمته، شـروحه، المحققين

(d)

المبحث الثالث في: ترجمة ابن الفخار وتشمل: (اسمه ونسبه وشهرته وكنيته،

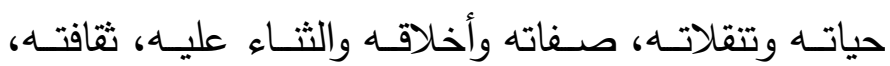

أساتذته، تلاميذه، آثاره، مؤلفاته، وفاته، عصره). 


\section{الفصل الأول}

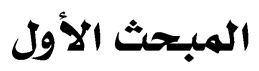

(1)

ترجمت الزجاجي (1)

* اسمه وكنيتهـ

هو عبد الرحمن بن إسحاق، أبو القاسم. يقف نسبه عند أبيه فلا يذكر

أحد شيئا عنه بعد ذلك. (r)

* نسبـه:- (2)

نسب الزجاجي إلى: نهاوند - جنوبي همذان - لذلك قال ابن خلكان:

(هو البغدادي داراً ونشأة، النهاوندي أصلا ومولدا). (َ)

ونسبه الإمام السيوطي (؛) إلى: الصيمرة - وهي في جنوبي همذان -

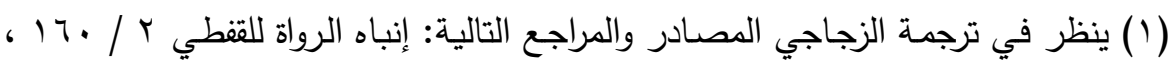

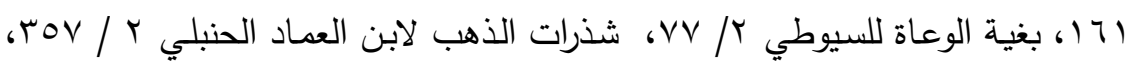

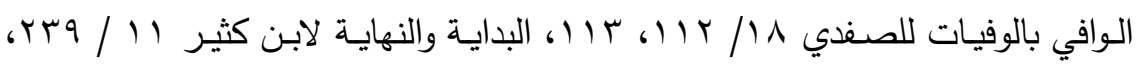

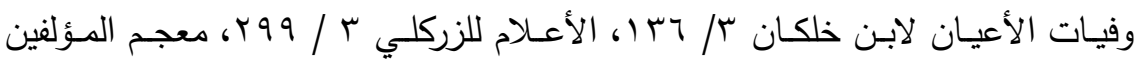

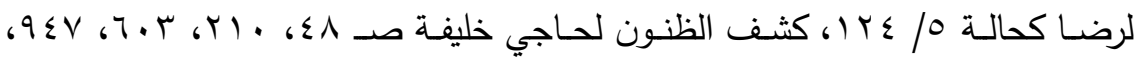

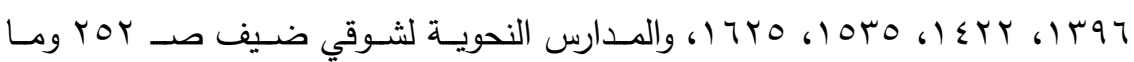

$$
\text { بعدها. }
$$

(Y) لعل لأصله الفارسي أثرا في ذلك، إذ لو كان عربيا لما ضـاع عنا نسبه، نظراً لما

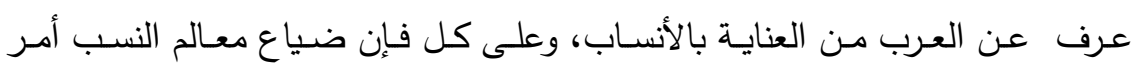

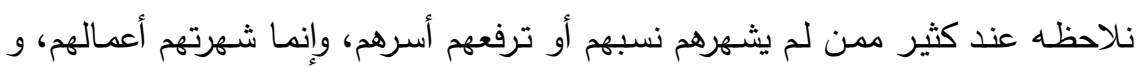
الزجاجي واحد من هؤلاء. ينظر : الزجاجي حياته وآثاره ومذهبه النحوي من خلال كتابه

$$
\begin{aligned}
& \text { لإيضاح د / مازن المبارك صد V. }
\end{aligned}
$$

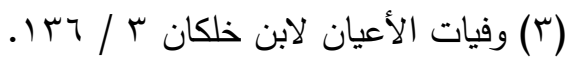

$$
\begin{aligned}
& \text { بغية الوعاة للسيوطي r / VV T. }
\end{aligned}
$$


حوليت كليت اللغت العربيت بإيتاى البارود (العدد الثاني والثلاثون - المجلد الرابع)

وجمع الققطي النسبتين فقال: (نهاوندي من أصل الصيمرة). (')

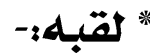

لقب بالزجاجي - بفتح الزاي وتشديد الجيم، وبعد الألف جيم ثانية -

وسمى بذلك لأنه صحب شيخه وأستاذه إبراهيم بن السرى الزجاج، فنسب إليه

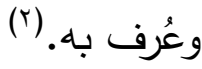

"مولده:-

ولد أبو القاسم الزجاجي بنهاوند ()، وقيل: في الصيمرة (؛) ولم يحدد

المؤرخون سنة ولادته.

*ثنأته وتنقلاته:-

نشأ الزجاجي بنهاوند - جنوبي همذان - ثم غادرها وانتقل إلى بغداد،

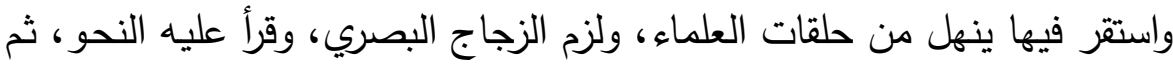
رحل إلى الثام فأقام بحلب مدة، ثم انتقل بعد ذلك إلى دمشق، واتخذها دار مقام له وأخذ يدرس في جامع بنى أمية، ويملي علي طلابه، ويصنف الكتب، ثم خرج

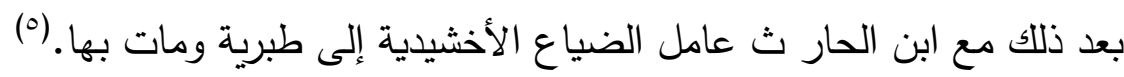

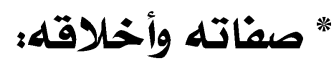

أجمع الذين تحدثوا عن الزجاجي أنه كان ورعا تقيا، وقالوا عن تأليفه

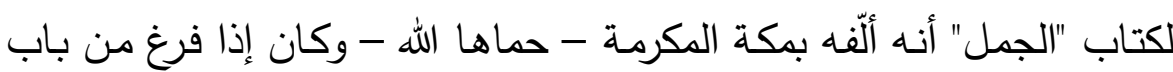

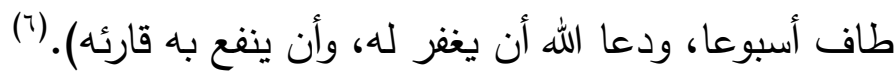

( (1) إنباه الرواة للقنطي ؟ / ـ 17 ويراجع: في التعريف بـ "نهاوند والصيمرة" معجم البلدان

$$
\text { لياقوت الحموي ( نهاوند - صيمرة). }
$$

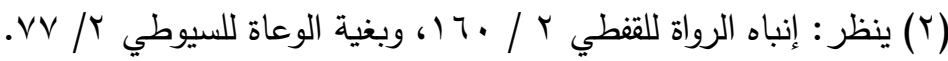

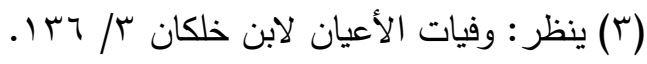

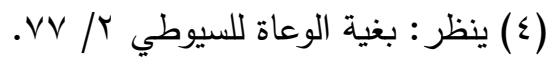

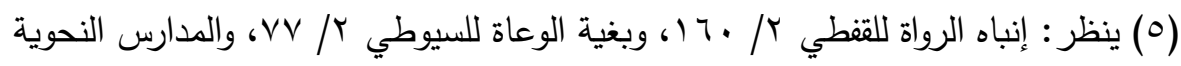

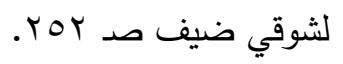

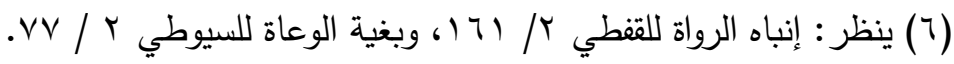




\section{دراسة موازنة بين منسجي الزجاجي وابن الفخار في تترح الجمل}

حوليت كليت اللغت العربيت بإيتاى البارود (العدد الثاني والثلاثون - المجلد الرابع)

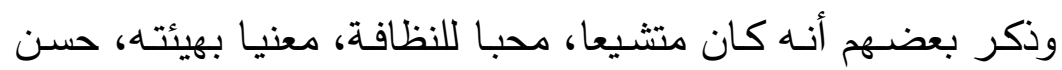

الثارة (')، مليح البزة (r). وكان ثقة يؤخذ عنه الحديث، ويتردد اسمه في الأسـانيد، قال الحافظ بن عساكر : (وحدث عن جماعه وأسند حديثا كثير) (r).

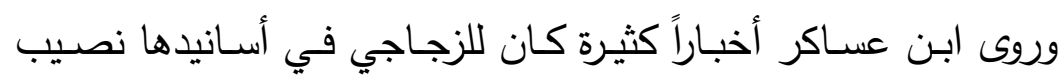
كبير (£) * شيوخه:تتلمذ الزجاجي على مشاهير العلماء في عصره، حيث التقى بهم في بغداد حاضرة العلم آنذاك، حيث كان لا يكاد يترك عالما إلا وأخذ عنه، وهذا لهاء

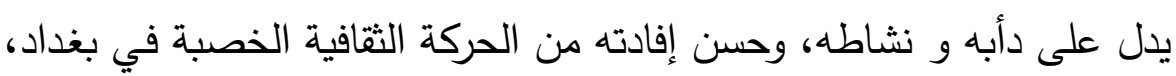
مما أتاح له ثقافة وافرة ومتتوعة في علوم العربية المختلفة، لكن كان انصرافه الظاهر للنحو والصرف، وأتناول هنا أبرز شيوخ الزجاجي وهم:ا - ابن كيسان:-

هو محمد بن أحمد بن إبراهيم بن كيسان أبو الحسن النحوي، كان يحفظ

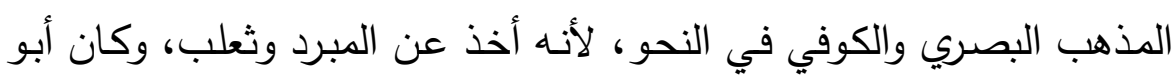
بكر بن مجاهد يقول: إنه أنحى منهما، قال عنه أبو حيان التوحيدي، ما رأيت مجلسا أكثر فائدة وأجمع لأصناف العلوم والتحف من مجلسه، وكان يجتمع مأنه

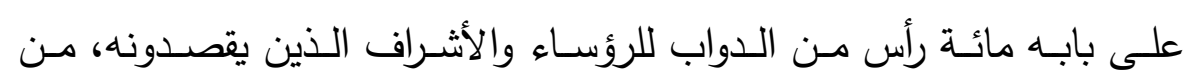

(1) يقال: إنسان حسن الثارة "أي" الهيئة، والثارة: الجمال الرائع، واللباس الحسن، واليَّمن

$$
\text { والزينة ينظر : المعجم الوسيط (شار ) ). }
$$

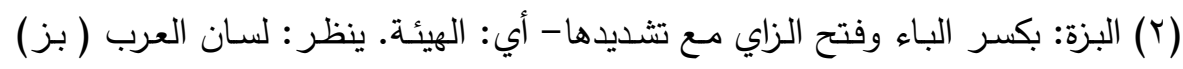

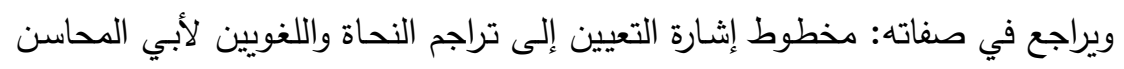

$$
\begin{aligned}
& \text { عبد الباقي الثافعي ورقة رقم (ب (Y). }
\end{aligned}
$$

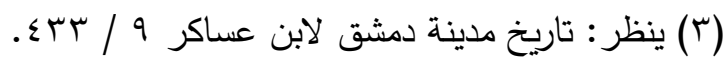

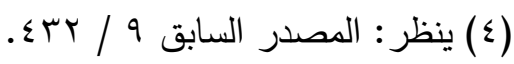


حوليت كليت اللغت العربيت بإيتاى البارود (العدد الثاني والثلاثون - المجلد الرابع) تصـانيفه: المهذب في النحو، غلط أدب الكاتب، البرهـان، غريـب الحديث، معاني القرآن، علل النحو وغير ذلك، توفى سنة عشرين وثلاثمائة('). r- أبو موسى الحامض:هو سليمان بن حمد بن أحمد أبو موسى النحوي البغدادي، المعروف بالحامض، كان أوحد المذكورين من العلماء بنحو الكوفيين، أخذ النحو عن ثعلب، وجلس موضـعه، وخلفه بعد موته، وروى عنه أبو عمر الزاهد، وغـلام نفطويـة كان دينـا صـالحا، أوحد النـاس في البيان والمعرفـة بالعربيـة واللغـة والثـعر، وإنمـا قيـل لـه الحـامض، لشراسـة أخلاقـه، مـن تصـانيفه: الوحوش، النبات، خلق الإنسان، المختصر في النحو مات سنة خمس وثلاثمائة. (ץ)

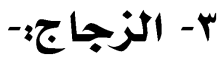

هو إبراهيم بن السري بن سـهل ، أبو إسـاق الزجاج، كان من أهل الفضل والدين، حسن الاعتقاد، كان يخرط الزجاج ثـم مـال إلى النحو، فلزم المبرد. وقد صـار من كتّاب القاسـم بن عبيد الله بن سليمان (وزير المعتضد العباسي) كانت له مناقشات كثيرة مع ثعلب وغيره من تصانيفه: إعراب القرآن، والاشتقاق، ومعاني القرآن، وفعلت وأفعلت، و شرح أبيات سيبويه، والقوافي، والنوادر ، وتفسير جامع المنطق توفى سنة إحدى عشرة وثلاثمائة. (r)

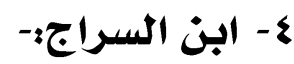

هو حمه بن السري البغدادي النحوي أبو بكر بن السراج، كان أحدث

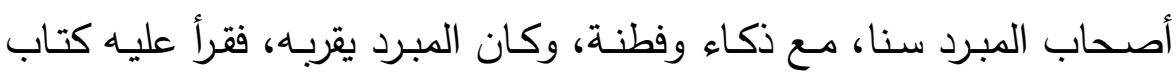
سيبويه، وكان عارفا بالموسيقى، ويقال: مـازال النحو مجنونا حتى عقله ابن

(1) ينظر ترجمته في : بغية الوعاة للسيوطي / / 1 1، 19، ومعجم الأدباء لياقوت الحموي $.1 T \Lambda$ / IV

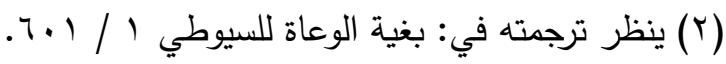

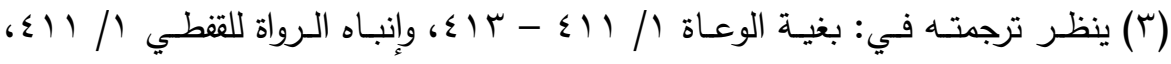

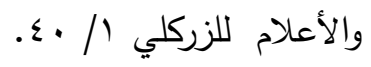


حوليت كليت اللغت العربيت بإيتاى البارود (العدد الثاني والثلاثون - المجلد الرابع)

السراج بأصسوله، أخذ عنه الزجاجي، والسيرافي، والفارسي والرماني، ولم تطل مدته ومات شابا سنة ست عشرة وثلاثمائة، وله من الكتب: الأصسول الكبير، والموجز ، وشرح كتاب سيبويه، والثعر والثعراء، والخط والهجاء، والمواصلات

والمذكرات في الأخبار وغيرها.(1)

\section{ه- محمد بن العباس اليزبلدي:-}

هو حمد بن العباس بن خحمد بن أبي حمد بن يحيى اليزيدي أبو عبد الله،

كان إمامسا في النحو والأدب، ونقل النوادر وأخبار العرب، حدث عن عمهه

عبيد الله، وعن أبي الفضل الرياشى وثعلب وغيرهم.

كـان راويـة للأخبـار والأدب، مصسدقا في حديثـه، لـه مـن الكتـب:

مختصر النحو، الخيل، مناقب ابن العباس، أخبار اليزيديين، مات سنة ثلاث

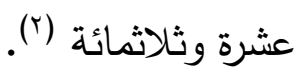

\section{-7 الأخمثث المغخيرة-}

هـو علي بـن سـليمان بـن الفضـل النحـوي أبـو الحسن. أحد الثلاثة

المشـهورين، قرأ على المبرد واليزيدي ولـم يكن بالمتسـع في الروايـة للأخبـار والعلم بالنحو ، وكان ابن الرومي يهجوه كثيراً، وكان ضيق الحال وانتهت الحال إليه أن أكل الثلجم النئ فقبض على قلبه فمات فجأة. له من التصانيف: شرح سيبويه، الأنواء، التثية والجمع، المهذب، تفسير رسـالة كتاب سيبويه، مـات سنة خمس عشرة وثلاثمائة (r).

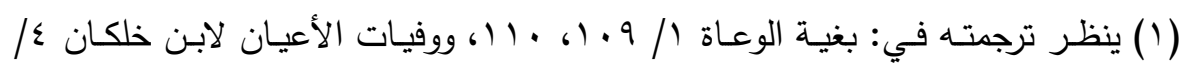

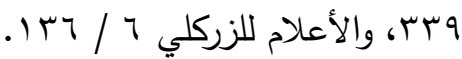

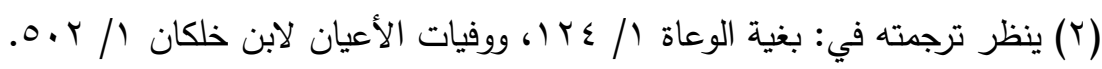

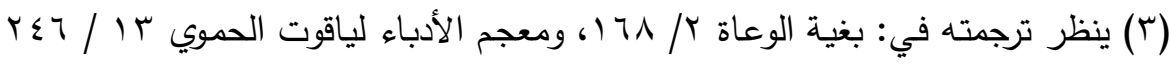


حوليت كليت اللغت العربيت بإيتاى البارود (العدد الثاني والثلاثون - المجلد الرابع)

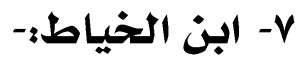

هو محمد بن أحمد بن منصور أبو بكر بن الخياط النحوي، أصله من

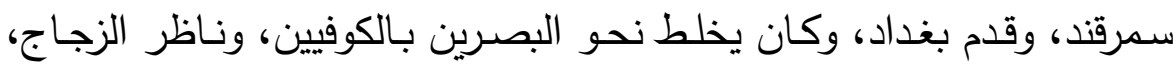
وأخذ عنه الزجاج والفارسي، كان حميد الأخلاق، طيب العشرة، صنف النحو الكبير، ومعـاني القرآن، والمقنع في النحو، والموجز فيه، مـات سنـه عشرين

وثلاثمائة. (1)

^- ابن دريل :-

هو تحمد بن الحسن بن دريد الأزدي، من أزد عمان من قحطان، هو أشعر العلماء، وأعلم الشعراء، ولد بالبصرة، وعاش في عمان مدة، وتقلد ديوان فارس، فمدح آل ميكال بقصيدته المشهورة "القصيدة الدريدية" ثم عاد إلى بغداد وفيها توفى من كتبه: المقصور والمدود، الاشتقاق المجتبى، الجمهرة وغيرها مات سنة إحدى وعشرين وثلاثمائة (r).

9- نفطظويه:-

هو إبراهيم بن حمحد بـن عرفـة بـن سليمان بن المغيرة بن حبيب بن

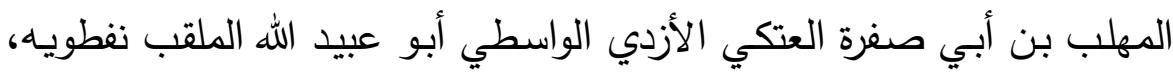
لشبهه بالنفط لدمامته وأدمته، وجعل على مثال سيبويه لانتسـابه في النحو النو

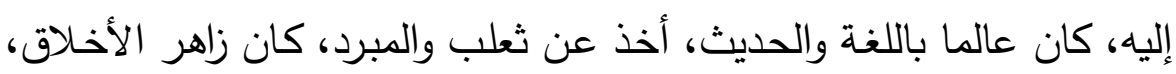

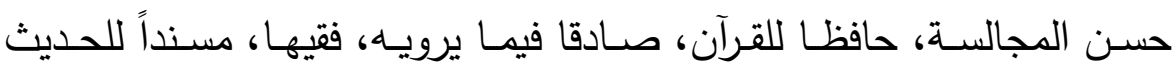
حافظـا للسـير وأيـام النـاس والتاريخ والوفيـات، مـن تصــنيفه: إعراب القـرآن، المقنع في النحو، الأمثال، المصادر، الرد على القائل بخلق القرآن، القوافي وغير ذلك، مات سنة ثلاث وعشرين وثلاثمائة ().

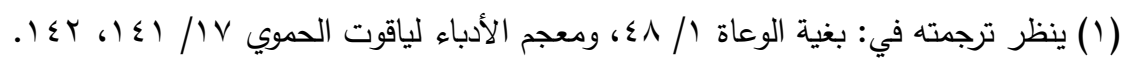

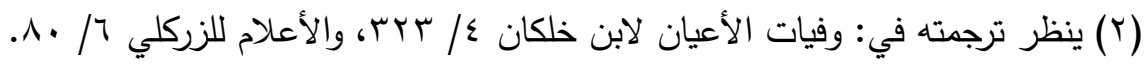

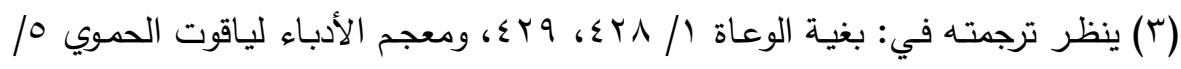
كمب وما بعدها. 
هو محمد بن القاسم بن محمد بن بشار بن الحسين بن بيان بن سماعه بن

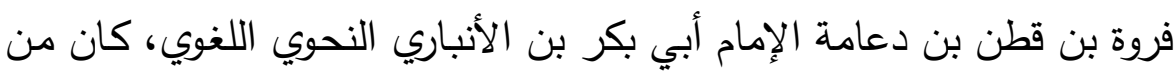

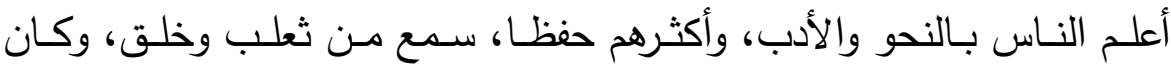
صدوقا فاضلا دينا خيرا من أهل السنة، وكان يحفظ ثلاثمائة ألف بيت شاهدا، وكان يملي من حفظه لا من كتاب، وكان مع حفظه زاهداً متواضعا، وكان

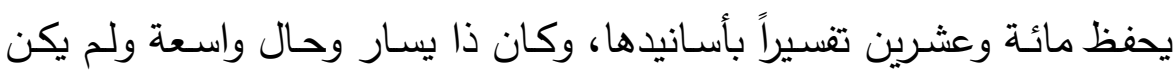

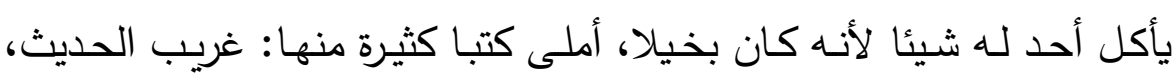

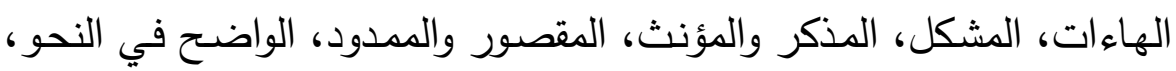
اللامات، شرح شعر الأعشى وشرح شعر النابغة وغير ذلك، مات سنة سبع وقيل ثمان وعشرين وثلاثمائة في بغداد (').

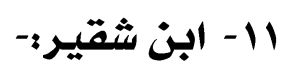

هو أحمـد بـن عبيد الله بـن الحسـن بـن شُقير أبـو العـلاء البغدادي

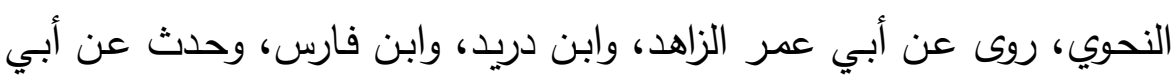
الهيثم خلف الدوري، وحامد بن شعيب البلخي وعنه تمام بن محمد الرازي وغيره

\section{ومن شيوخ الزجاجي أيضا ممن لهر أقف لهم على ترجمترة-}

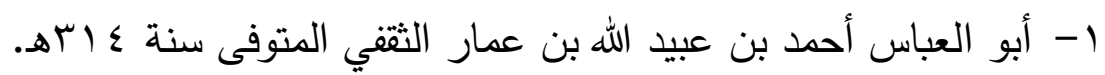
r- أبو القاسم جعفر بن قدامه الكاتب المتوفى سنة 9 آآهـ.

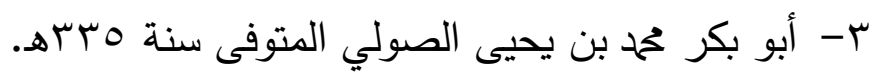

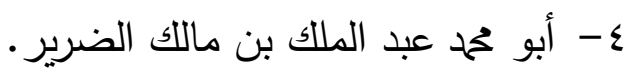
0- أبو عبد الله الحسين بن ححمد الرازي.

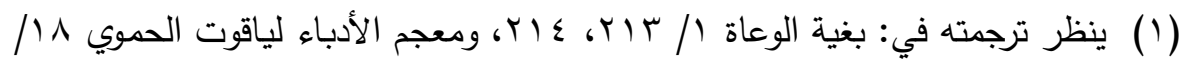

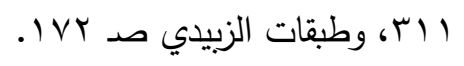

(r) (Yن) 
حوليت كليت اللغت العربيت بإيتاى البارود (العدد الثاني والثلاثون - المجلد الرابع) צ- أبو على الحسن بن على العتري.

- أبو الفضل الملقب بزبيل (') هؤلاء هم الأعلام الذين أخذ عنهم الزجاجي وتخرج بهم، وكان منهم البصريون كما كان منهم الكوفيون، وكان لذلك آثار ظهرت في آراء الزجاجي ومؤلفاته. * تلاميذه (r)

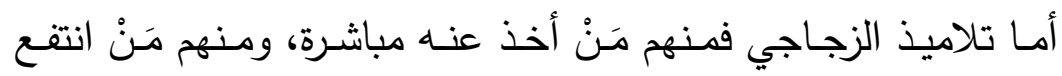
بكتبه، وقد كان يحب أن ينفع الله الناس بعلمه وكان مثّن أخذ عن الزجاجي:1- - محمد بن سابقة النحوي الدمشقي. r- عبد الرحمن بن عمر بن نصر .

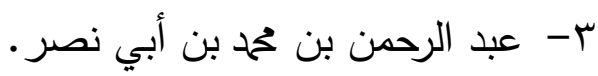
ع - أحمد بن محمد بن سلامة.

- أبو الحسن على بن حمح بن إسماعيل بن قحمد التميمي الأنطاكي. 7- أبو بكر أحمد بن ححمد بن أحمد بن سلمه بن شرام النحوي. - V أحمد بن على الجبال الحلبي. - v - أبو يعقوب إسحاق بن أحمد الطائي. 9- الحسين عبد الرحيم المعروف بأبى الزلازل. • أبو الحسن السبتي.... وغيرهم. ويلاحظ أن أكثر تلاميذ الزجاجي كانوا من "دمشق" ولعل سبب ذللك أنه أقام في "دمشق" أكثر مما أقام في غيرها، وفيها حدّث وأملى وألف.

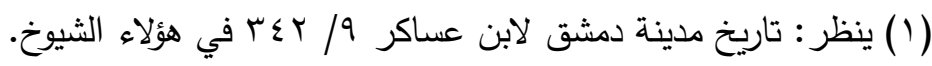

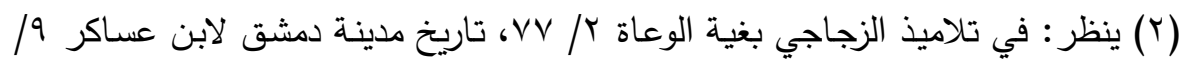

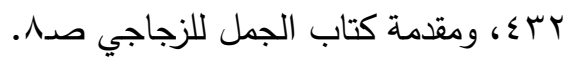




\section{دراسة موازنة بين منسجي الزجاجي وابن الفخار في تترح الجمل}

حوليت كليت اللغت العربيت بإيتاى البارود (العدد الثاني والثلاثون - المجلد الرابع) جـاء في مقدمـة كتاب الجمل: (ثم سكن دمشتق وطبريسة وأيلـة فأملى

$$
\text { وحدث ولا سيما بدمشق) ('). }
$$

وقال القفطي: (وانتقل إلى الشام فأقام بحلب مدة، ثم انتقل إلى دمشق

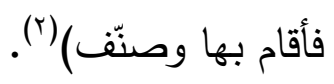

والذين انتفعوا بتأليف الزجاجي فكثيرون ، وكأن المؤلفين لما سمعوا

خبر ورعه وتقاه ودعائه أن ينفع الله الناس بعلمه وقعوا تحت تأثيره، وتتاقلوا خبر النفع بكتبه حتى إنـه ما من أحد منهم ذكر كتاب (الجمل) للزجاجي إلا

وصفه بالبركة والنفع العظيم (r).

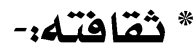

- لقد كانت ثقافة الزجاجي ثقافة عالم عاش في أواخر القرن الثالث الهجري، وأدرك أربعين سنة من القرن الرابع الهجري، هذا القرن الذي حفل بنتاج خصب للعقلية الإسلامية في أوج نضجها ورقيها، حيث عاصر ابن السراج، وابن الأنباري، والزجـاج، وابـن دريد وغيـرهم، وكان واحداً مـنهم، بـل مـن أكثرهم نشاطا في العلم والتأليف.

- وتظهر لنا ثقافة الزجاجي الواسعة في مؤلفاته الكثيرة، وما تتصف به من عمق وتتوع، وكأنه جمع في نفسه ما تفرق عند شيوخه من فنون العلم، فقد كان منهم مَنْ اتسـع أفقه في النحو كالأخفش الصـغير، وابن كيسان، وابن الخياط فكان الزجاجي مثلهم في سعة العلم بالنحو ، وكان منهم مَنْ غلب عليه علم اللغة كابن دريد، وأبى موسى الحامض فكان الزجاجي كذلك لغويا كما هو في كتابه (الآمالي).

(1) (1) ينظر : مقدمة الجمل للزجاجي صـ ^. (Y) ينظر : إنباه الرواة للقفطي / / 17 (T)

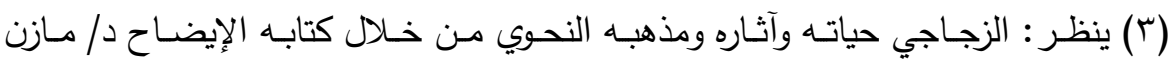

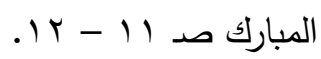


حوليت كليت اللغت العربيت بإيتاى البارود (العدد الثاني والثلاثون - المجلد الرابع)

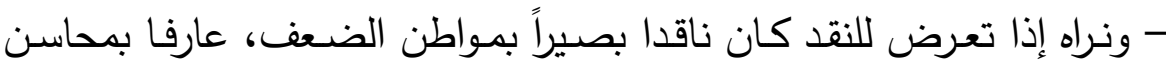
التـأليف، فهـو يكـره الجمـع والتقليـد، ويحـب الإبـداع والابتكــار، والوضـوح والسلامة من الخطأ، ويتضح هذا في نقده للمفضل صاحب كتاب (الفاخر)

$$
\text { ولابن الأنباري صاحب كتاب (الزاهر). }
$$

- وقد اشتهر الزجاجي بكثرة تآليفه حتى عرف بصاحب التصانيف، وكانت تصـانيفه متتوعـة الموضـوعات ففيهـا: النحـو والصـرف، وحـروف الهجــاء

$$
\text { والمعاني، والقوافي، والشعر ، واللغة والأدب('). }
$$

- ولم تكن ثقافة الزجاجي عربية فحسب بل كان عارفا لبعض اللغات الأخرى،

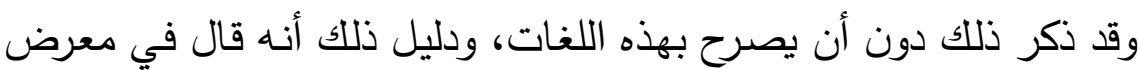
حديثه عن أقسام الكلام وكونها لا تخرج عن الاسم والفعل والحرف:-

(وقد اعتبرنا ذلك في عدة لغات عرفناها سوى العربية فوجدناه كذلك)(r). - لقد كان الفارسي أستاذ عصره، متقدم أهل الصنعة في زمانها، وأنحى مَنْ

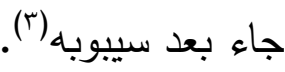

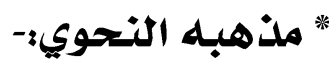

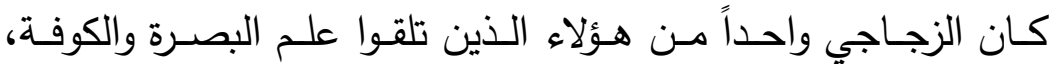
وبسطوا أقوال علماء المذهبين جميعا منتخبين منها ما يرون أنه الحق. وليس غرببـا أن يكـون معظم شـيوخ الزجـاجي مدـن خلط المـذهبين

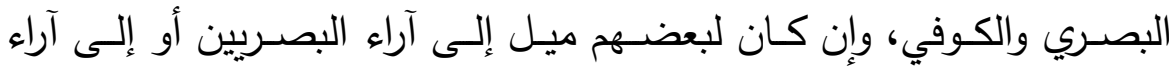

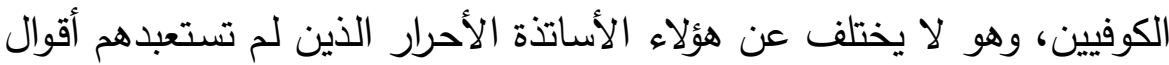

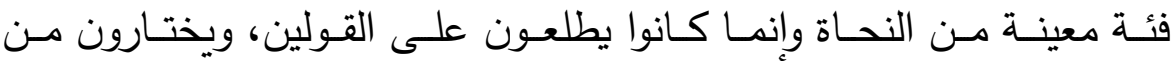
المذهبين.

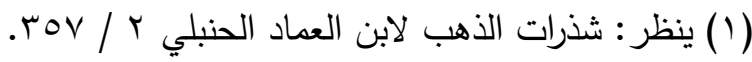

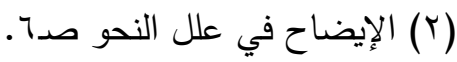
(r) ينظر : الزجاجي حياته وآثاره ومذهبه النحوي من خلال كتابه الإيضساح للدكتور / مازن

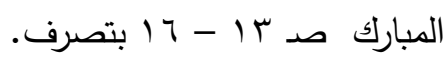




\section{دراسة موازنة بين منسجي الزجاجهي وابن الفخار في تترح الجمل}

حوليت كليت اللغت العربيت بإيتاى البارود (العدد الثاني والثلاثون - المجلد الرابع) وكان الزجاجي مستقل الشخصية حر الفكر لا هو بالبصري المحض، ولا بالكوفي المحض، يرى الرأي فلا يخشى أن يخالف فيه من سبقه كوفيا كان أو بصريا، وقد يذكر الرأيين ثم يصف أحدهما بما يدل على تأييده للثاني كأن

يقول: (وإن قلت كذا كان قبيحا، وأهل البصرة لا يجزونه).(') أو يقول بعد ذكر رأيه: (هذا هو الوجه الجيد). (r) وقد يعرض لأكثر مسن رأي واحد فيصـنف الآراء تصـنيفاً يسير فيه ليه بحسب القوة والضعف في رأيه كأن يقول: (الأجود في هذا الباب كذا، وبعد ذللك كذا.... ودون ذللك كله كذا....). (r) - أما إذا أردنا أن نتعرف على مذهبه من خلال استعماله للمصطلحات، فكان الزجاجي لا تهمهـ الأسـاء بقدر مـا يهمهـ أن يوضـح مراده، ويقرب المعنى إنى من الفهم، فنراه يستعمل الأسـاء المختلفة للمسـى الواحد كقوله: (الفصل

$$
\text { ويسميه الكوفيون العماد)(ع). }
$$

كما نراه يصرح بتغيير ألفاظ الذين يحكى عنهير فيقول: (وإنمـا نذكر هذه الأجوبة عن الكوفيين...إلا أن العبارة عن ذلك بغير (ألفاظهم)(م)

وهو لا يفعل ذلك تعصبا ضدهم بل رغبة منه في التوضيح كما يقول:(لأنه لو تكلفنا حكاية ألفاظهم بأعيانها، لكان في نقل ذلك مشقة علينا من غير زيـادة في الفائدة، بل لعل أكثر ألفاظهم لا يفههها مَنْ لم ينظر في كتبهم)( (7)

$$
\begin{aligned}
& \text { (1) ينظر : الجمل للزجاجي صـ ، 10. }
\end{aligned}
$$

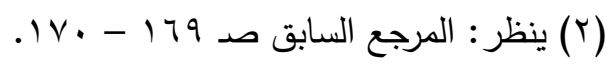

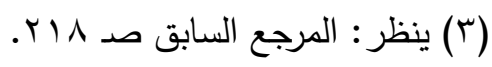

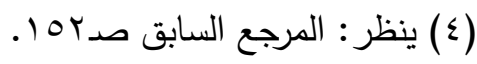

$$
\begin{aligned}
& \text { (0) ينظر : الإيضاح في علل النحو للزجاجي صدY.V. }
\end{aligned}
$$

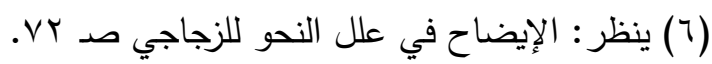


حوليت كليت اللغت العربيت بإيتاى البارود (العدد الثاني والثلاثون - المجلد الرابع)

وذقول:-

إن الزجاجي كان كأكثر شيوخه الذين لم يكونوا بصريين خلصسا، ولا

كوفيين خلصا، وإنما كانوا ذوى نزعة تجديدية تمزج بين نحوى البصرة والكوفة، وتأخذ من محاسنهما، تاركة العصبية المذهبية جانبا، فلم تكن ثقافتهم النحوية بصرية محضة، ولا كوفية محضة، وإنما كانت مزاجا من الثقافتين وانتقاءً من المذهبين، وإن كان أخذها من أحدهما يتفاوت قوة وضعفا، وكثرة وقلة. ومع هذا التفاوت فقد ظهر مَيْل الزجاجي إلى البصرين حين عدّ نفسه

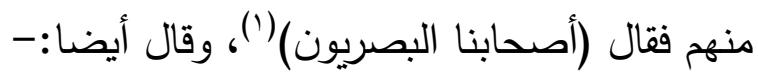

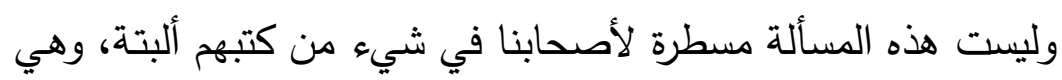

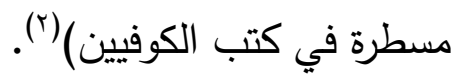
ولعل هذا الميل إلى أراء البصريين يرجع إلى تأثير الزجاج في تلميذه

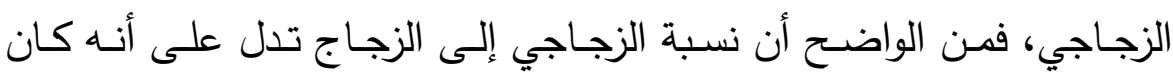
أستاذه المفضل، وشيخه الأول.

كما أن هذا الميل لا يعنى أنه كان متعصباً ضد الكوفيين، بل كانت

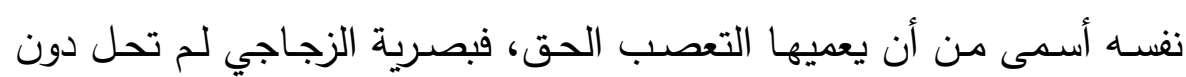
استعماله مصطلحات(广) الكوفيين، بل هو على العكس كثيرًا ما كان يستعملها في مصنفاته، وهو يبسط آراء الكوفيين، ويذكر أحسن احتجاجاته، ولا يغلظ لهم القول إن رد عليهم، شأنه في ذلك شأن العالم المنصف المتزن.

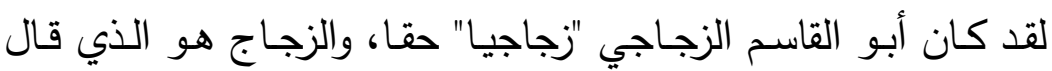
حين عوتب على تركة ثعلبا والتزامه المبرد:-

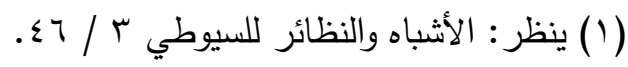

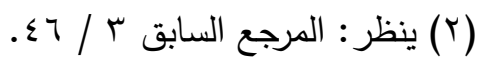

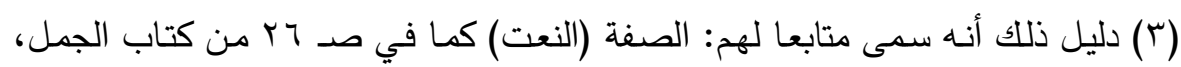
وسمى نائب الفاعل (اسم مالم يسم فاعله) كما في صدی من من كتاب الجمل. 
حوليت كليت اللغت العربيت بإيتاى البارود (العدد الثاني والثلاثون - المجلد الرابع)

(لست أقول بالذكر والخمول ولكني أقول بالعلم والنظر)(').

وكذلك كان تلميذه أبو القاسم الزجاجي لا يقول بالميْل والهوى ولكنه

يقول بالعلم والحق.

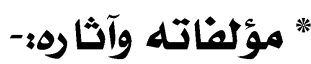

ورد في المراجح والمصـادر التي ترجمـ للزجـاجي كثير من أسـماء

الكتب التي ألفها الزجاجي لكن لـ يصل إلينا دن هذه الكتب إلا القليل، وهذه

الكتب في النحو والصرف واللغة، وما وصل إلينا لا يقل عن عشرين مؤلفا في

علوم العربية المختلفة، وهذه الكتب بحسب ترتيبها الألفبائي هي:-

ا الإبدال والمعاقبة والنظائر (r).

r- الإذكار بالمسائل الفقهية(r).

ب- اشتقاق أسماء الله تعـالى وصفاته المستتبطة مـن التتزيل ومـا يتعلق

بها من اللغات والمصادر والتأويل (ء).

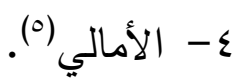

0- الإيضاح في علل النحو (ج).

ج- بيان الأسئلة الواردة على البسملة وأجوبتها(V).

(1) ينظر : الأشباه و النظائر للسيوطي / / 7؛، ويراجع: الزجاجي حياته و آثاره ومذهبه

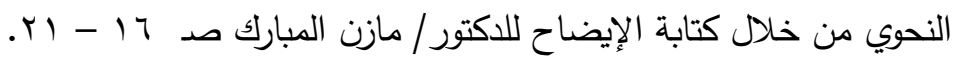

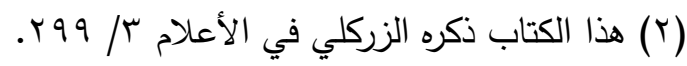

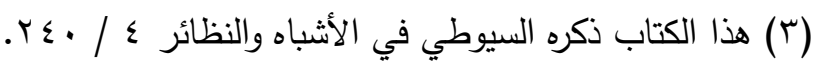

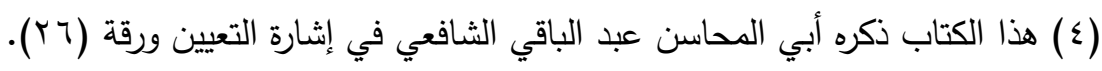

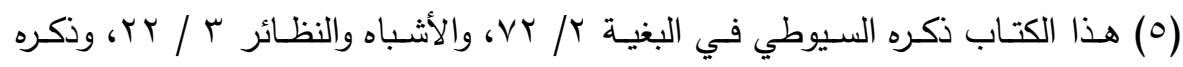

البغدادي في خزانة الأدب ك/ 9 • 1.

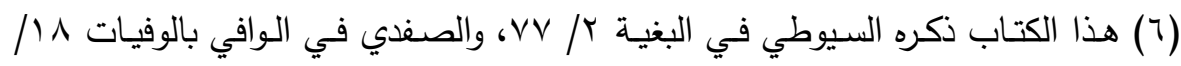


حوليت كليت اللغت العربيت بإيتاى البارود (العدد الثاني والثلاثون - المجلد الرابع)

V - الجزولية وهي حواشٍ على كتب "الجمل"(1).

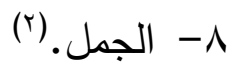

و- الزاهر في معاني الكلام ويسمى أيضًا "اختصسار الزاهر"، "ومختصر

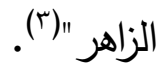

• . - شرح خطبة أدب الكاتب لابن قتيبة.(£)

11- شرح رسالة كتاب سيبويه(0).

r ا - شرح كتاب الألف واللام للمازني في النحو (־).

با - غرائب مجالس النحوين الزائدة على تصنيف المصنفين(V).

؟ ا- الكافي في النحو (^).

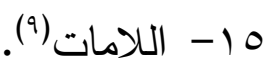

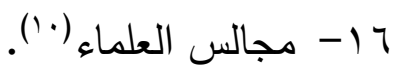

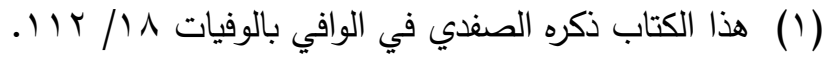

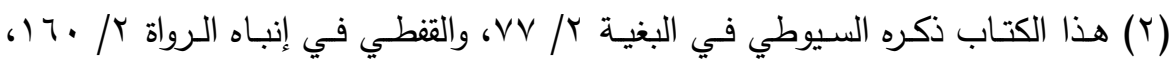

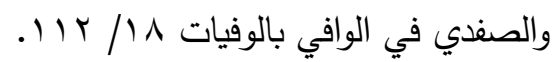

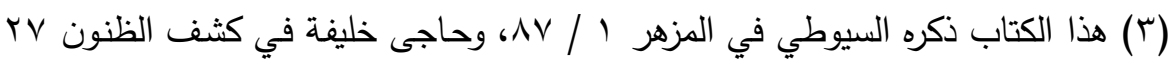

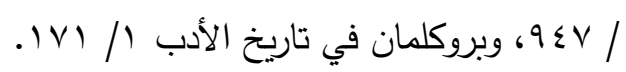

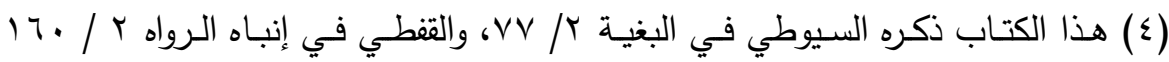

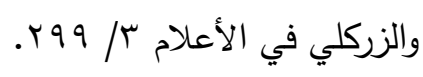

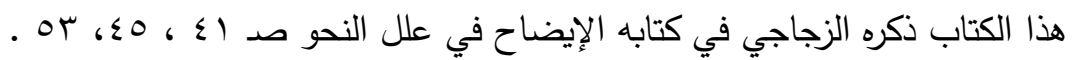

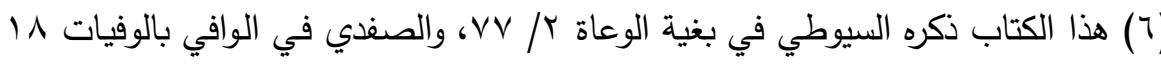

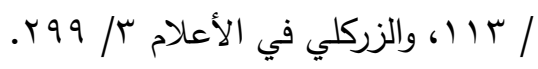

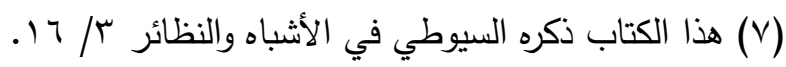

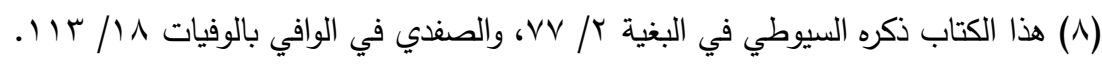

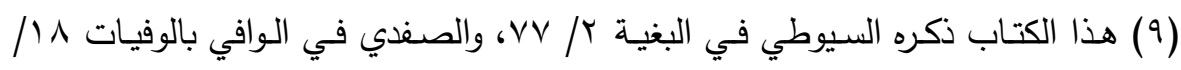

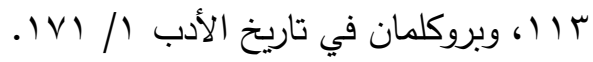

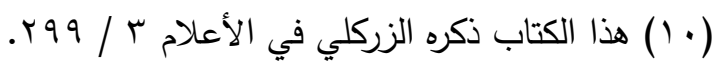


حوليت كليت اللغت العربيت بإيتاى البارود (العدد الثاني والثلاثون - المجلد الرابع)

IV

1 ا- المخترع في القوافي (r).

( 19

.

ا ا- ومن آثار الزجاجي أيضا (مسائل متفرقة) جمعها في كتاب بعث به

إلى أبي بكر الشيباني، وكان قد سأله عن بعضها، فدفعه السؤال إلى

الجمـع والتأليف فقد جـاء في الأشباه والنظـائر : (هذه إحدى عشـرة

مسالة، سأل عنها أبو بكر الشيباني أبا القاسم الزجاجي في كتاب إب إهـ

أنفده إليه من طبرية إلى دمشق...)(م).

ثم كتب له الجواب و أورد جواب الإحدى عشرة مسألة.

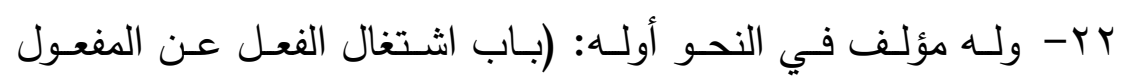

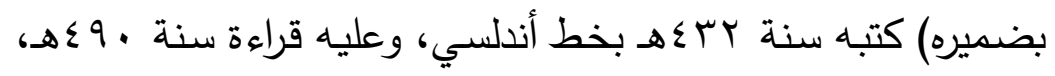

وهو في (Y ( ) ) صفحة في خزانة الحسين بن حمد الإصريني ببلدته

إصريف في السوس (؟).

* وفاته:-

اختلف الذين ترجموا للزجاجي في سنة وفاته على ثلاثة آراء:-

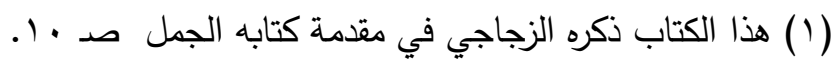

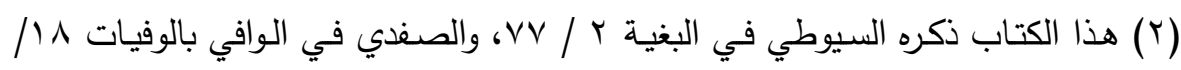

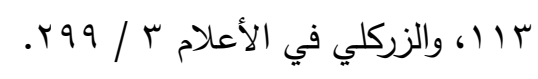

(r) هذا الكتاب ذكره ابن خير في فهرسته صـ 9 ابس.

(ع) هذا الكتاب ذكره الزجاجي في الجمل في باب: الأفعال المهموزة صـ ا9 ب، وبروكلمان

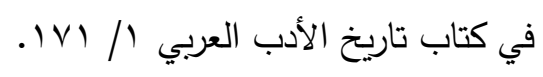

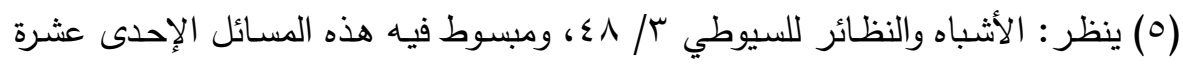

وجوابها.

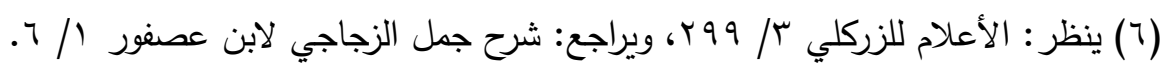




\section{دراسة موازنة بين منسجي الزجاجي وابن الفخار فهي تترح الجمل}

حوليت كليت اللغت العربيت بإيتاى البارود (العدد الثاني والثلاثون - المجلد الرابع)

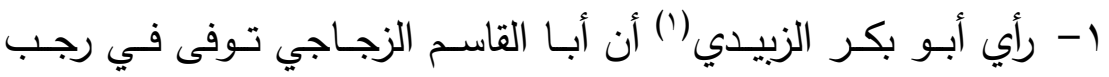

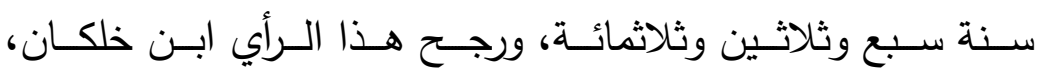

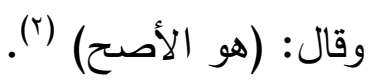

ץ- وزعم ابن تغري بردي(r) أن وفاة الزجاجي كانت في ذي الحجة سنة

تسع وثلاثين وثلاثمائة، وقال بذلك أيضاً الإمام السيوطي (ء).

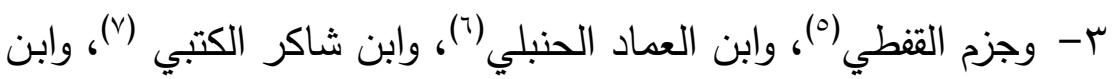
عساكر (^) أن وفاة الزجاجي كانت في رمضان سنة أربعين وثلاثمائة.

\section{$-1$}

$$
\begin{aligned}
& \text { (1) ينظر : طبقات النحويين واللغويين للزبيدي صـ 9 ا I. }
\end{aligned}
$$

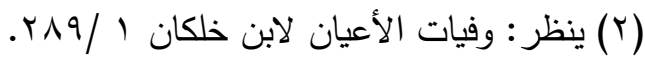

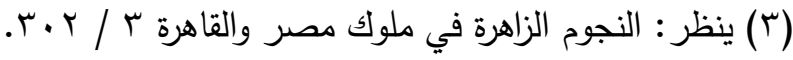

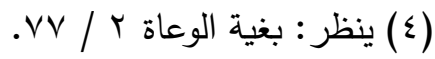

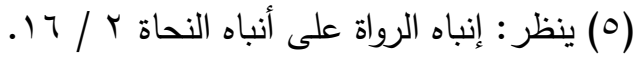

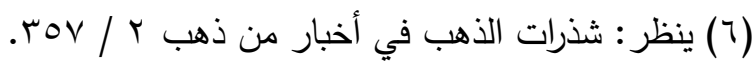

ين (V)

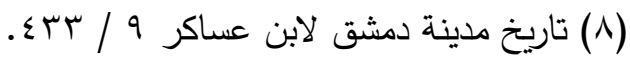




\section{المبحث الثاني}

\section{التعريف بكتاب "الجمل" للزجاجي}

\section{موضوع الموازتن}

" موضوع كتاب "الجمل" للزجاجي:-

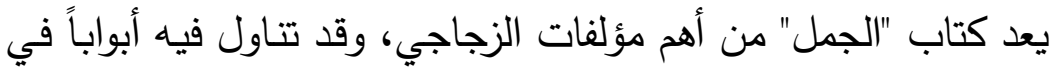

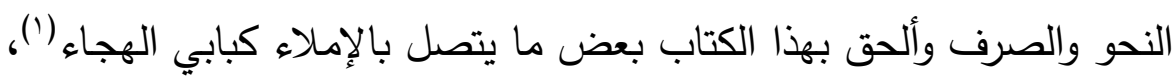

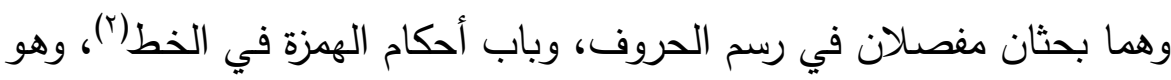
بحث في قواعد الهمزة الإملائيـة ومـا دار حولها مـن خـلاف بين البصـرين والكوفيين الذين امتد اختلافهم في النحو حتى شمل قواعد الخط فكان لكل منهم رأي فيه.

وتعرض في كتابه أيضـا للضرورات الشعرية، وخصها بباب عنوانه:

(ما يجوز للشاعر أن يستعمله في ضرورة الشعر)(r) لكنه جاء بابا موجزا خاليا من الثواهد والأمثلة على خلاف عادته في الكتاب.

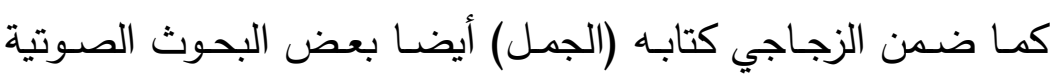

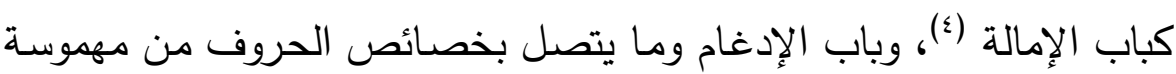

$$
\text { ومجهورة(0). متن كتاب "الجمل" : "- }
$$

بالعودة لمتن كتاب "الجمل" نجده قد ضم ستة وأربعين ومائحة باب تناولت موضوعات: النحو والصرف والضرورات الشعرية والأصوات، وهنا لا لاتهين بد لي من ذكر هذه الأبواب حسب ترتيبها في كتاب " الجمل " للحاجة إليها

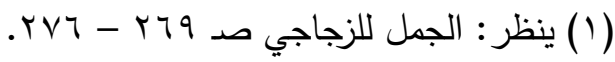

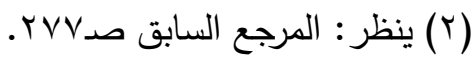

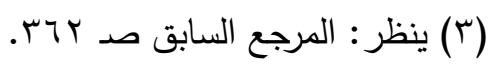

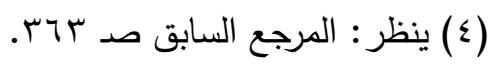

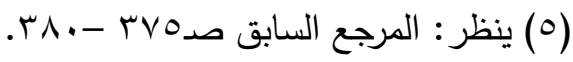




\section{دراسة موازنة بين منسجي الزجاجي وابن الفخار في تترح الجمل}

حوليت كليت اللغت العربيت بإيتاى البارود (العدد الثاني والثلاثون - المجلد الرابع) عند عقد الموازنـة بـين كتاب "الجمـل للزجـاجي وكتاب "شـرح الجمـل" لابـن - مخار

\section{وترتيب هذه الأبواب حسب ورودها(') جاء علي النحو التالي:-} باب الإعراب، باب معرفة علامة الإعراب، باب الأفعال، باب التثنية والجمـع، بـاب ذكر الفاعل والمفعول، بـاب مـا يتبع الاسـم في إعرابـ، بـاب النعت، باب العطف، باب التوكيد، باب البدل، باب أقسام الأفعال في التعدي، بـاب مـا تتعدي إليـه الأفعـال المتعديـة وغير المتعديـة، بـاب الابتداء، بـاب اشتغال الفعل عن المفعول بضميره، باب الحروف التي ترفع الاسم وتتصب الخبر، باب الحروف التي تتصب الاسم وترفع الخبر ، باب الفرق بين إنّ وأنّ، باب حروف الخفض، باب حتي في الأسماء، باب القسم وحروفه، باب ما لم يسم فاعلة، باب من مـا لم يسم فاعله، باب اسم الفاعل، باب الأمثلة التي تعمل عمل اسم الفاعل، باب الصفة المشبهة باسم الفاعل فيما تعمل فيه، باب التعجب، باب ما، باب نعم وبئس، باب حبذا، باب الفاعلين المفعولين يفعل كل واحد منهمـا بصساحبة مثل مـا يفعله الآخر ، بـاب مـا يجوز تقديمهـ مـن المضدر علي الظاهر وما لا يجوز ، باب إضـافة المصدر إلي ما بعده، باب العدد، باب تعريف العدد، باب ثاني اثنين وثالث ثلاثة، باب مـا يحمل من العدد علي اللفظ لا علي المعني، باب كم، باب منذ ومذ، باب الجمع بين إن وكان، باب الفصل ويسميه الكوفيون العماد، باب الإضافة، باب التأريخ، باب النداء، باب الاسمين اللذين لفظهما واحد والآخر منهما مضاف، باب إضافة المنادي إلي المتكلم، باب ما لا يجوز فيه إلا إثبات الياء، باب ما لا يقع في النداء خاصـة ولا يستعمل في غيره، باب الاستغاثة، باب الترخيم، بـاب مـا رخمت الثعراء في النداء اضطرارًا، باب الندبة، باب المعرفة والنكرة، باب الحروف التي تنصب الأفعال المستقبلة، باب الجواب بالفاء، باب أو، باب

$$
\text { (1) ينظر : فهارس كتاب الجمل للزجاجي (فهرسة الأبواب) ص 0مب-1 صץ. }
$$




\section{دراسة موازنة بين منسجي الزجاجي وابن الفخار في تترح الجمل}

حوليت كليت اللغت العربيت بإيتاى البارود (العدد الثاني والثلاثون - المجلد الرابع)

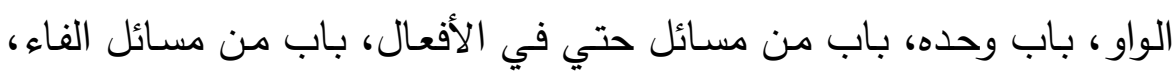

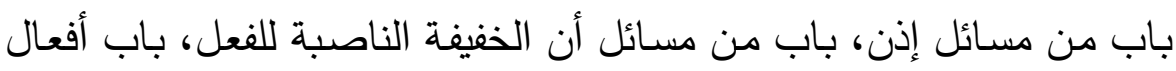
المقاربـة، باب من المفعول المحمول علي المعني، باب الحروف التي تجزم

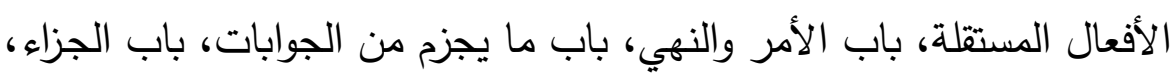

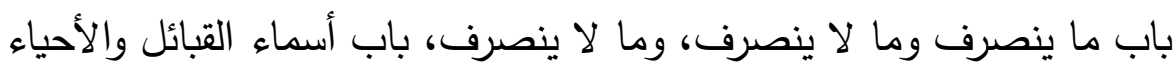
والسور والبلدان، باب ما جاء من المعدول علي فعال، باب الاستثناء، باب

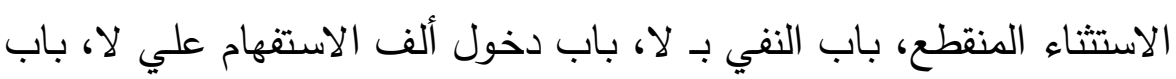

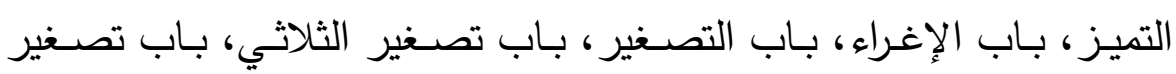
الرباعي، باب تصغير الخماسي، باب تصغير الظروف، باب تصغير الأسماء

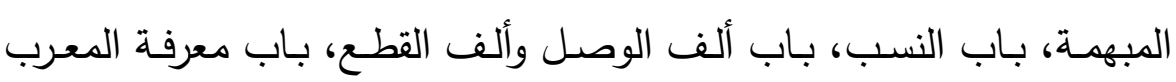
والمبني باب المخاطبة، باب الهجاء، باب آخر من الهجاء، باب نوع آخر من بن باب لهن

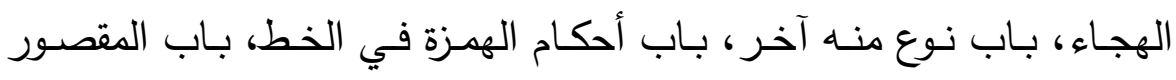
والممدود، باب المذكر والمؤنث، باب ما يؤنث من جسد الإنسـان ولا يجوز تذكيره، باب ما يؤنث من غير أعضاء الحيوان ولا يجوز تذكيره، باب ما يذكر

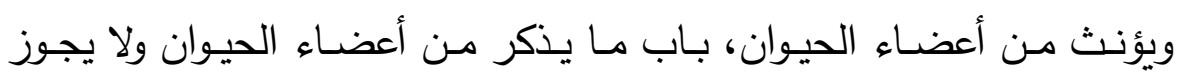

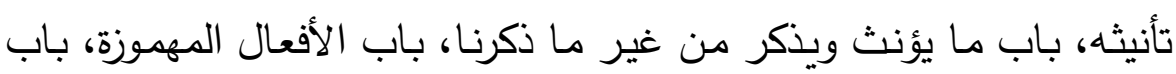

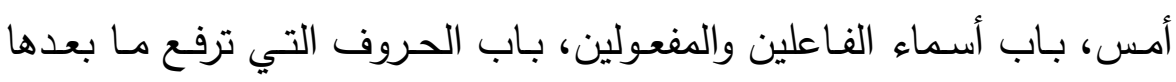

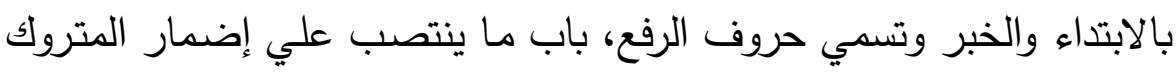

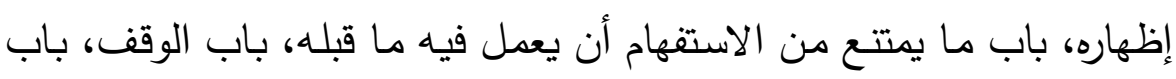
لو ولولا، باب مـا جاء من المثثي بلفظ الجمع، باب مـا يحذف منـه التنوين

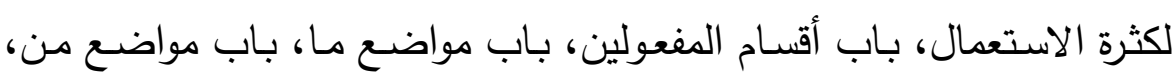

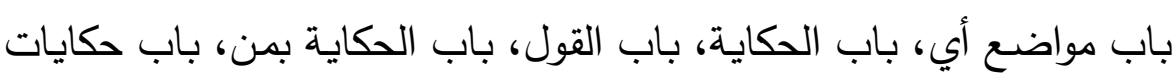

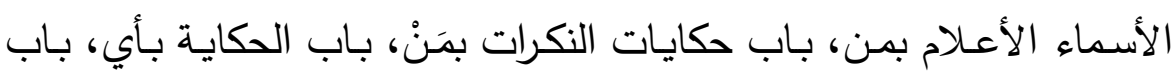

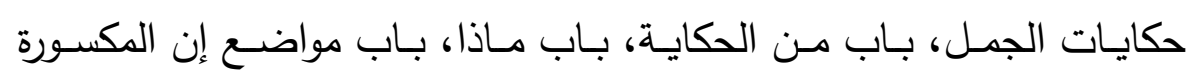
الخفيفة، باب مواضع أن المفتوحة المخففة، باب الجواب ببلي ونعم، باب أم و 


\section{دراسة موازنة بين منسجي الزجاجي وابن الفخار في تترح الجمل}

حوليت كليت اللغت العربيت بإيتاى البارود (العدد الثاني والثلاثون - المجلد الرابع) أو، بـاب النـون الثقيلـة والخفيفـة، بـاب الصـلات، بـاب الجمـع المكسر ، بـاب معرفة أبنية أقل العدد، باب تكسير ما كان علي أربعة أحرف وفيه حرف لين، بـاب جمع مـا كان على أفعل، بـاب تكسير مـا كان على فاعل، بـاب تكسير مـا كان على أربعـة أحرف أو خمسـة، بـاب جمـع كان علي فَعْلـة أو

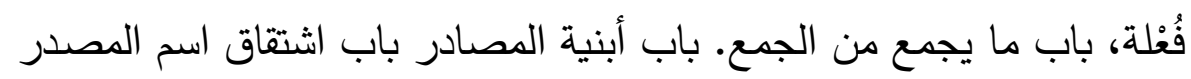
والمكان، باب أبنية الأسماء، باب ما يجوز للشاعر أن يستعمله في ضرورة

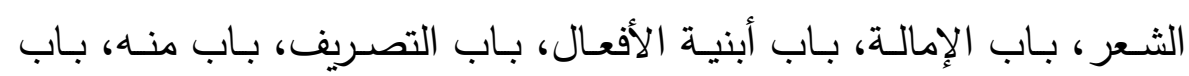
الإدغـام، بـاب الحـروف المهوسـة، بـاب الحـروف المجهورة، بـاب حـروف

الإطباق، باب من شواذ الإدغام. (')

\section{* أسلوب كتاب "اخجمل" :}

عرض الزجـاجي موضـوعات، ومـتن كتاب (الجمل) بأسـلوب سـهل واضـح، خـال من التعقيد وجفاف الحدود والقواعد؛ ليصـل إلي تقريـر وتقعيد قواعد النحو بيسر و سهولة، مع براعة في تحليل القواعد والتعليل لها، مما يشد القارئ إلي متابعة القراءة دون إحساس بضجر أو نفور • وقد أكثر الزجاجي في هذا الكتاب مـن الثـواهد القرآنيـة والثـعرية، وكذلك الأمثلة وتظهر رغبة الزجاجي في توضيح النحو وتقريبه حين يهجر بعض المصطلحات أو يفسرها ليكون كلامه أقرب إلي الفهم، خالٍ من التعقيد، ويصرح نفسه بذللك قائلا:--

(وليس هذا من ألفاظ البصرين ولكنة تقريب علي المبتدئ).)(r) وكذلك حينما ينقل ألفاظ الكوفيين بغير عباراتهم فيقول:-

(فأكثر ألفاظهم لا يفهمها إلا مَنْ تَعود النظر في كتبهم).

(1) ينظر فهرسة الأبواب من كتاب الجمل للزجاجى ص 0رى- (وب.

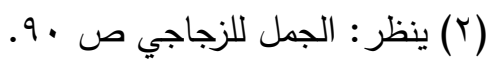

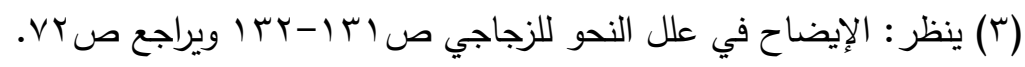




\section{دراسة موازنة بين منسجي الزجاجي وابن الفخار في تترح الجمل}

حوليت كليت اللغت العربيت بإيتاى البارود (العدد الثاني والثلاثون - المجلد الرابع)

فأسلوب كتاب (الجمل) أسلوب أدبي عذب، يعني بتقريب النحو إلي أفهام الناس عامـة، وأفهام المبتدئين خاصـة، فهو مناسب لمستوي المتعلمين، وفي الوقت نفسه لا يعدم المتخصصون منه الفائدة.

\section{"منهج كتاب "اثجمل" : "}

يبدو من منهج الزجاجي أنه تعليمي: لأنه كان ينهي كل باب تقرببا

بما يفيد ذلك كقولة:

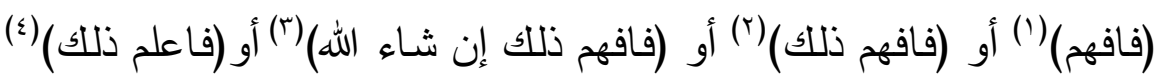

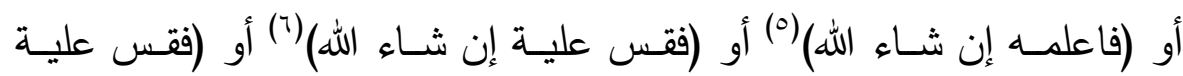
تصب إن شاء الله)('). أو (لتعرفها إن شاء الله) (^) ونحو ذلك.

ولعل هذا المنهج يعد شاهداً علي سهولة منهج التأليف في علم النحو

في العصور المتقدمـة، وخلوه من الحدود المنطقية الجافة أو التقريعات التي تميل إلي الافتراضات، وتتأى بنا عن صفاء اللغة العربية. فمنهج كتاب (الجمل) جيدُ، ومن تمام الجودة فيه وضوح الأمثلة، وقل أن نجد بين كتب النحو القديمة مثل هذا الكتاب وضوحاً وبيانا. وليس عيبـا أن يخرج الزجـاجي عمـا وضـعه سـيبويه مـن مـنهج في التأليف قائم علي الإيجاز والاختصسار ، والبخل بتوضسيح المثال، حتي بات كتاب سيبويه لا يفهــه إلا فقهاء العلم. فكتب النحو كلهـا لا توضـع لطبقـة

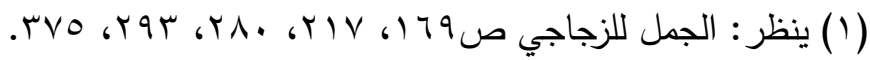

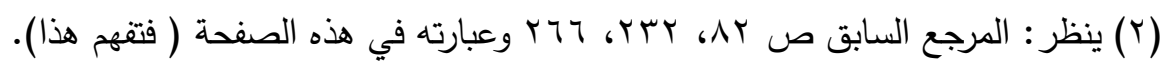

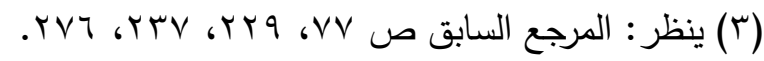

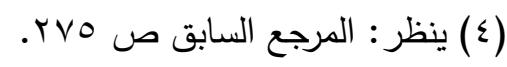

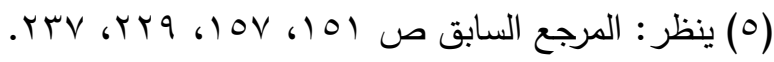

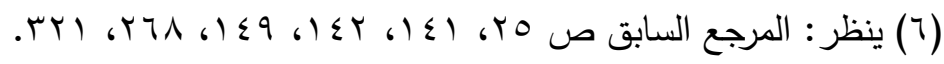
ين (V) (^) ينظر : المرجع السابق ص (^) 


\section{دراسة موازنة بين منسجي الزجاجه وابن الفخار في تترح الجمل}

حوليت كليت اللغت العربيت بإيتاى البارود (العدد الثاني والثلاثون - المجلد الرابع)

واحدة من الناس؛ فلئن كان كتاب سيبويه وأمثاله يصلح للشيوخ الذين تعمقوا في العلم، ووقفوا علي دقائقه وأسـراره، فـإن كتاب (الجمل) للزجـاجي وأمثاله لينفع المبتدئين في النحو، والمتطلعين إلي تعلمه(1). وذلك لأن كتاب (الجمل) كما قال عنه الققطي:-

كانت طريقته في النحو متوسطة، وتصانيفه يقصد بها الإفادة).(r) بـل وقد شهد لـه بعض العلمـاء أنه بتآليفه فتح أنظارهم علي النحو وله ودليل ذلك قول ابـن السيد البطليوسـي: (وإنـه مـن أئمسة هذه الصـناعة، فإنـا بكتابة قد افتحنا النظر في هذا العلم. وهوالذي رشح بصسائرنا لما منحناه من

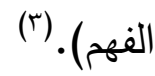

\section{قيمت كتثاب (الجمل ) للزجاجي:-}

كان لكتاب "الجمل " قيمـة علمية كبيرة في عصره، حتي انشـل بـه النـاس وجعلوا همهم حفظله، وقد نـال هذا الكتاب شهرة مدوية في العصسور الوسطي.

ومما يدل علي قيمة هذا الكتاب العلمية قول القفطي:(وهو كتاب المصرين وأهل المغرب وأهل الحجاز واليمن والشام إلي

أن اشتغل الناس باللمع لابن جني، والإيضاح لأبي علي الفارسي).(؛) وقول اليافعي: (ولعمري إن كتابا عظم النفع به مع وضوح عبارته وكثرة أمثلته هو جمل الزجاجي وهو كتاب مبارك ما اشتخل به أحد في بـلاد الإسـلام علي

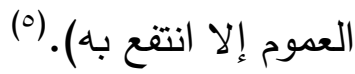

(1) ينظر : الزجـاجي حياتـه وآثـاره ومذهبه النحـوي مـن خـلال كتابـه الإيضـاح د/ مـازن

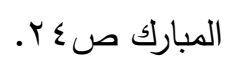

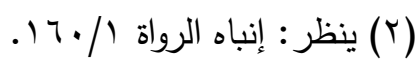

(r) ينظر : إصلاح الخلل الواقع في كتاب الجمل لابن السيد البطليوسي ورقة رقم (1).

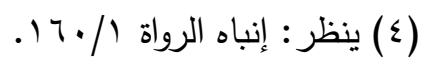

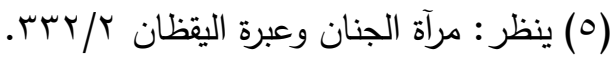




\section{دراسة موازنة بين منسجي الزجاجي وابن الفخار في تترح الجمل}

حوليت كليت اللغت العربيت بإيتاى البارود (العدد الثاني والثلاثون - المجلد الرابع)

وقول الفهري: (أكثر الناس من استعمال الجمل ودراسته، وألزموا أنفسهم حفظه

وروايته...، وانه تصنيف قد أنجد وغار ، وطار في الآفاق كل مطار (1).

وقول ابن خلكان: (وكتابه الجمل من الكتب المباركة لم يشتغل بـه أحد إلا

وانتفع به( (r) (برن)

وقول ابن العمـاد الحنبلي: (أنه انتفع بكتابه يعني جمل الزجاجي -

خلق لا يحصون)(r) وقال حاجي خليفة في معرض حديثه عن كتاب (الجمل)

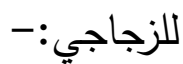

(وهو كتاب نافع ومفيد)(ع).

شروح كتاب (اتجمل):-

نـال هذا الكتاب شـرة مدويـة، وذاع صسيته في العصسور الوسطي، إذ

عكف عليـه العلمـاء بالـدرس والشـرح، حيـث شـروح الثـواهد، أو التعقيب، أو التعليق، وقد بلغت شروح هذا الكتاب في المغرب وحده "مائة وعشرين شرحاً"، ولا بد من الإشارة هنا إلي أن هذا الكتاب له نسختان: كبري وصغري(م)، وأن أكثر هذه الشـروح كانت للكبرى، ولم تطبح جميع هذه الشـروح، بـل ضـاع أكثرها.

وأقتصر هنا علي ذكر جملة من أشهر هذه الشروح (؟) وهي:-

(1) ينظر : مقدمة وشي الحلل في شرح أبيات الجمل لأبي علي الحسين بن عبد العزيز الفهري.

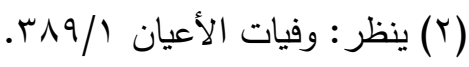

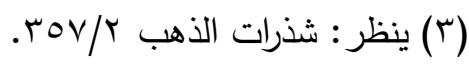

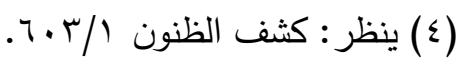

(0) من شروح الصغرى: شرح ابن بابشاذ الذي شرح الجمل, ألف كتابا في الزيادة التي بين

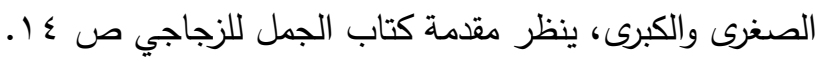

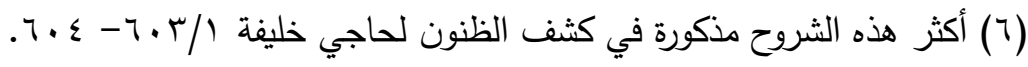


حوليت كليت اللغت العربيت بإيتاى البارود (العدد الثاني والثلاثون - المجلد الرابع) 1 شرح الجمل لأبي القاسم الحسين بن الوليد المعروف بابن العريف المتوفي

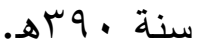

Y- عـون الجمـل وهـو شـرح لشـواهد الجمـل لأبـي العـلاء أحمـد بـن عبـد الله

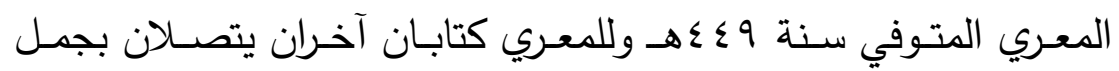

\section{الزجاجي وهما "تعليق الجليس" و "إسعاف الصديق"(1).}

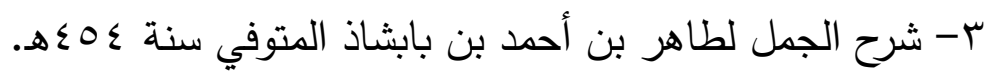
ع - شرح أبيات الجمل لابن سيدة علي بن إسماعيل المتوفى سنة ^مــــ ه- شرح الجمل لأبي الحجاج يوسف بن سليمان المعروف بالأعلم الشنتمري

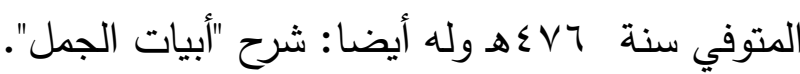

ج- إصـلاح الخلل الواقع في الجمل لأبي محمد عبد الله بن السيد البطليوسي المتـوفي سـنة إOبهـ، وقـال عنـه حـاجي خليفـة: (إنـهـ أحسـن شـروح

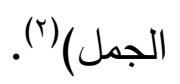

- V

$$
\text { أبيات (الجمل) وينسبها إلي قائليها. }
$$

م- شرح أبيات الجمل للشريشي المتوفي سنة . ع ه هـ(؟). 9- شرح أبيات الجمل لأبي العباس أحمد بن عبد الجليل التدميري المتوفي

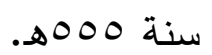

• 1 - المجمل في شرح أبيات الجمل لابن هشام اللخمي المتوفي سنة . 70ـه. 11- شرح الجمل لأبي الحسن علي بن حمد المعروف بابن خروف الأندلسي

$$
\text { المتوفي سنة } 7 \text {. 7هـ. }
$$

r ا - شرح أبيات الجمل لعلي بن عبد الله الوهراني المتوفي سنة 1 آهـ.

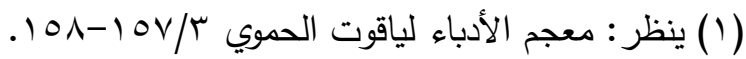

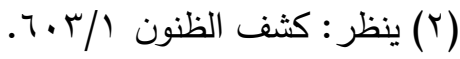

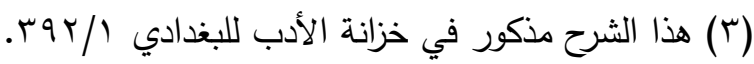




\section{دراسة موازنة بين منسجي الزجاجي وابن الفخار في تترح الجمل}

حوليت كليت اللغت العربيت بإيتاى البارود (العدد الثاني والثلاثون - المجلد الرابع)

ب ا- شـرح الجمل لأبي الحسن علي بن محم بن عصفور الإشبيلي المتوفي

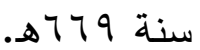

ع ا- شـرح الجمل لأبي الحسن علي بـ محم بن علي بـن يوسف الإشبيلي المعروف بابن الضائع المتوفي سنة . ـ1 آهـ.

1 - وشي الحلل في شرح أبيات الجمل لأبي علي الحسين بن عبد العزيز الفهري البلنسي المتوفي سنة ا 9 هـ.

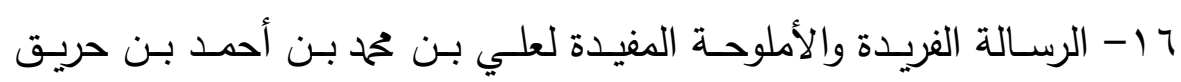

البلنسي المتوفي في أوائل القرن السابع الهجري(').

V V شرح الجمل لـحمد بن علي بن أحمد بن خحم بن هذيل الخولاني الإلبيري

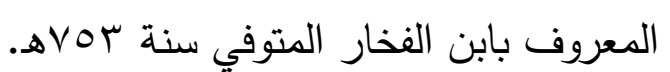

1 ا - شرح الجمل لجمال الدين عبد الله بن يوسف بن هثام النحوي المتوفي

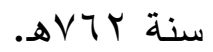

9 1 - تقييد علي بعض جمل الزجاجي لأبي سعيد فرح بن قاسم بن أحمد بن

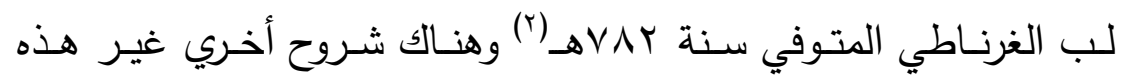
الثروح ذكرها حاجي خليفة، ولابد من التببيه هنا علي أن السيوطي قد نقل (r) كثيرا من جمل الزجاجي وأقوال شارحيه في كتبه، ولاسيما كتاب

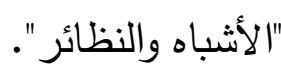

(1) هذه الرسالة مذكورة في مقدمة كتاب الجمل للزجاجي صـ با ، وذكرها بروكلمان في

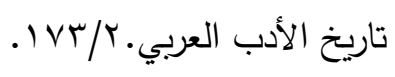

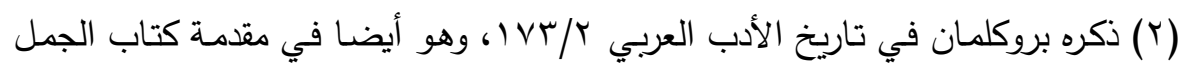

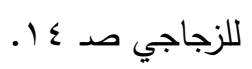

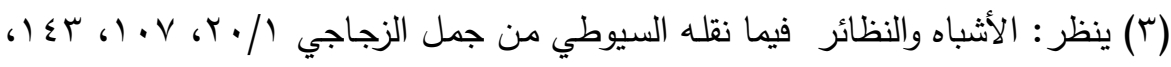

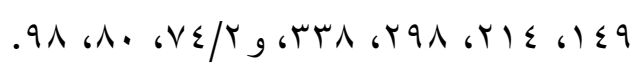


1- هذا الكتاب حققه الأستاذ الثيخ ابن أبي شنب، الأستاذ بكلية الآداب في الجزائر، وكان قد طبع في عام سنة جب 9 (هـ، في مطبعة جول كربونل بالجزائر، وهذه هي النسخة التي اعتمدت عليها في عقد الموزانة بين

$$
\text { (الجمل) للزجاجي و (شرح الجمل) لابن الفخار . }
$$

وجاء في آخر هذه النسخة أن المستشرق الألماني يوحنس بولف طبع في

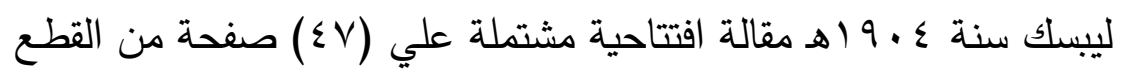

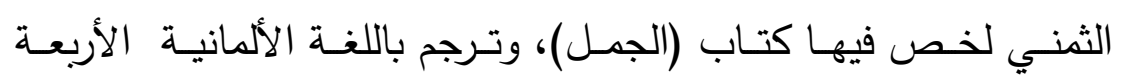
والستين شـاهدا الأولي فقط - أي إلي صـ 1 1 أمن هذه الطبعة - ولم

ينبه عن تركه باقي الثواهد. (') ץ- كما أن هذا الكتاب طبع أيضا بعنوان:- (الجمل في النحو )، وحققه دم/

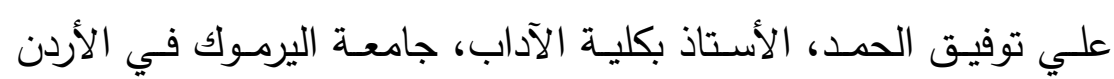

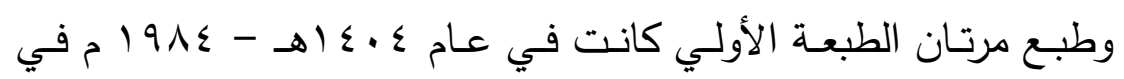

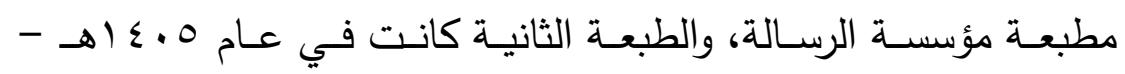
1910 ام في مطبعة الرسالة أيضا.

\section{$-4$}

(1) ينظر : الجمل للزجاجي صد זمr. 
حوليت كليت اللغت العربيت بإيتاى البارود (العدد الثاني والثلاثون - المجلد الرابع)

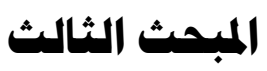

ترجمهن ابن الثنخار (1)

*** اسمه ونسبه وشهرته وكنيته:-

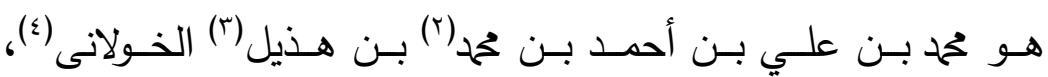

الإلبيري(ه)، يكني بأبي عبد الله.

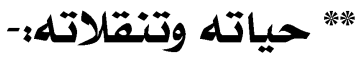

عاش ابن الفخار طفولته الأولي في غرناطة التي هي عاصمة إقليم

"إلبيرة" المنسوب إليها، ثم انتقل بعد ذلك إلي مدينة "سبته" بالمغرب، في سن

مبكرة من عمره لطلب العلم وكان أسـاتذته المعروفين من أهل "سبتة" كمحد بن

(1) ينظر في ترجمة ابن الفخار المصادر والمراجع التالية - الإحاطة في أخبار غرناطة

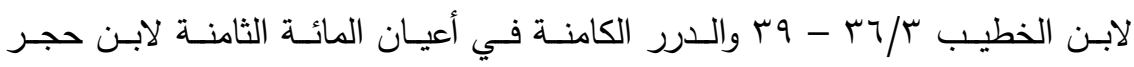

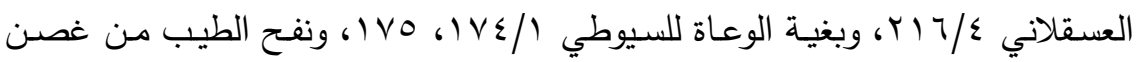
الأندلس الرطيب للمقري 00/0 - وهب، وشذرات الذهب في أخبار من ذهب لابن

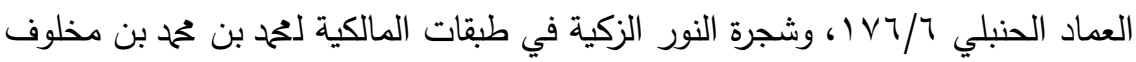

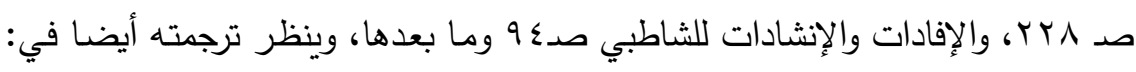
- برنامج المنتوري لآبي عبد الله محمد بن عبد الله المنتوري (مخطوط) صد س، . r، . ب،

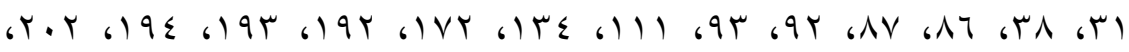
צr

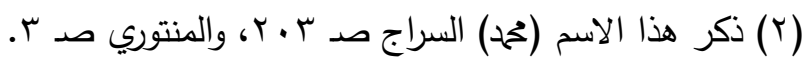
(r) ذكر هذه الزيادة (هذيل) المنتوري صـ ب وهذيل نسبة إلي: هذيل بن مدركة، وهي قبيلة كبيرة وأكثر أهل وادي نخلـة المجاور لمكة - حرسـها الله - هذليون من هذه القبيلة، هذية

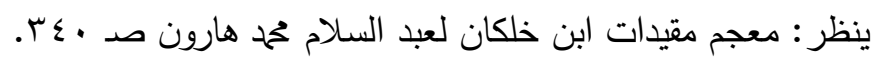

(ع) الخولاني: هذه النسبة إلي: خولان بن عمرو، وهي قبيلة كبيرة نزلت بالثـام، ينظر

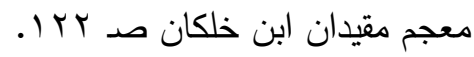
(0) الإلبيري: هذه النسبة إلي: "إلبيرة "، وإلبيرة: كورة كبيرة بالأندلس تضم عدة مدن منها:غرناطة التي أقام فيها ابن الفخار حتي توفي بها، ينظر : معجم البلدان لياقوت الحموي

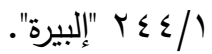


حوليت كليت اللغت العربيت بإيتاى البارود (العدد الثاني والثلاثون - المجلد الرابع)

عبد المهيمن الحضرمي، وحضر (') ابن الفخار بعض مجالس العلم في مدينة "فاس" أيضـا بـالمغرب، وكان يجيب علي الأسئلة التي توجه إليه في علم النحو مما يدل علي أنه قد علا كعبه في هذا الفن. وبعد أن انتهي من فترة طلب العلم في:- مدينتي: "سبتة"و "فاس"، انتصب للتدريس(r) في مدينة "مالقة" بالأندلس، ثم انتقل بعد ذلك إلي مدينة: غرناطسة وهي بالأندلس أيضـا، وانتصسب فيها للتدريس بالمدرسـة "النصـرية"، وقام بالخطبة بالجامع الأعظم، وكان في تلك الفترة ممن انتقل في السفارة إلي

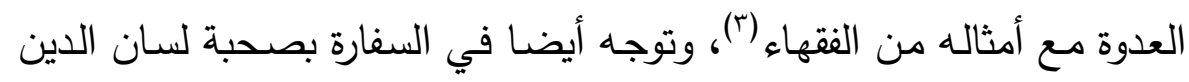
بن الخطيب(؛) وكانت له حيث حل الشهرة وعليه الازدحام، وقل من لم يأخذ عنه من الطلبة. (0)

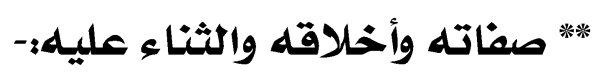

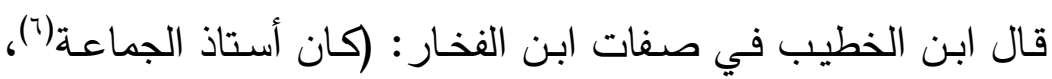
وعلم الصناعة، وسيبويه العصر ، وآخر الطبقة من هذا الفن، وكان فاضـلاً، تقيا، متعبدا، عاكفا علي العلم، ملازماً للتدريس، إمام الأئمسة من غير مدافع، مبرزاً أمـام أعـلام البصـينين مـن النحاة، منتشر الذكر ، بعيد الصيت، عظيم الثـهرة، مستبحر الحفظ، يتفجر بالعربيـة تفجر البحر ، ويسترسـل استرسـال القطر ، قد خالطت لحمه ودمه، لا يشكل عليه منها مشكل، ولا يعوزه توجيه.

$$
\text { (1) ينظر : الإفادات والإنشادات للشاطبي صـ هبا . }
$$

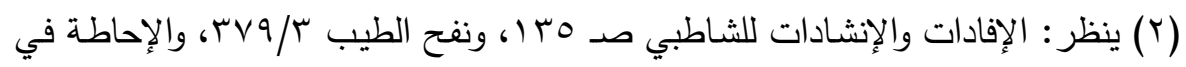
أخبار غرناطة وV/r.

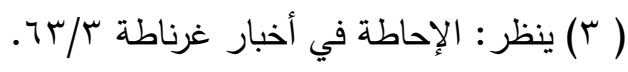

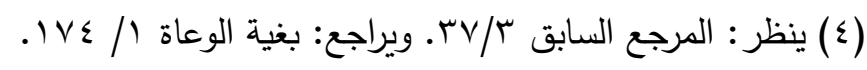

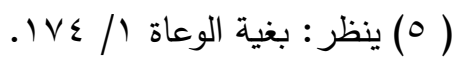

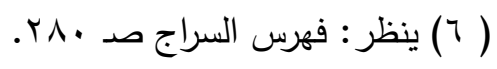


حوليت كليت اللغت العربيت بإيتاى البارود (العدد الثاني والثلاثون - المجلد الرابع) ولا تشذ عنه حجة، جدد بالأندلس ما كان قد درس من العربية، من لدن وفاة أبي علي الشلوبين ('). وكان مقتصدا في أحواله، وقورا، مفرط الطول، نحيفا، سـربع الخطو، قليـل الالتفـات، متوسـط الـزي، قليـل الـدهاء والتصـنع، غريـب النزعة، جامعا بين الحرص والقناعة)(r).

\section{ومن الصمّات التي وصف بها ابن المنخار أيضا كها ذكر المقري:} (أنه الإمام المجمع علي إمامته في فن العربية، المفتوح عليه من الله

فيها حفظا، واضطلاعا، ونقلاً، توجيهاً بما لا مطدع فيه لسواه)(").

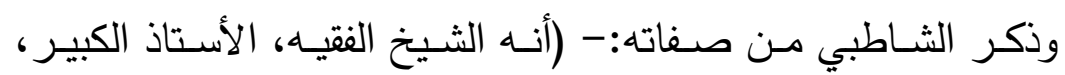
النحوي الثهير، العلم الخطير)(؛)، وذكر السراج أنه: (أستاذ الجماعة، ورئيس النحاة بغرناطة)(ن).

ومما يدل علي صلاحه وتقواه ما ذكره أبو إسحاق الشاطبي: من أنه دعا الله أن يريه إياه في المنام، فيوصيه بوصية ينتفع بها في الحالة التي هو عليها من طلب العلم. قال: فلما نمـ تلك الليلة رأيت كأني أدخل عليه في داره التي كان يسكن بها، فقلت له: ياسيدي أوصني، فقال لي: لا تعترض علي أحد)(؟).

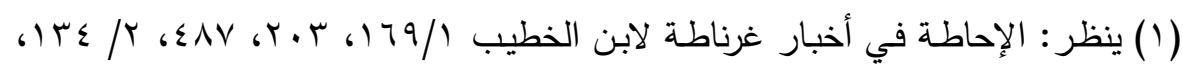

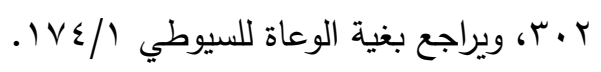

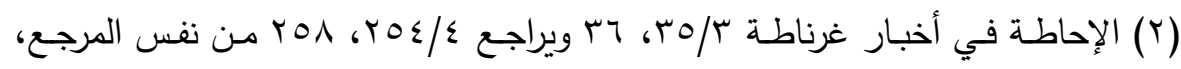

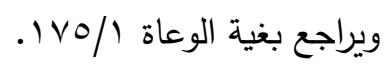

(r) ينظر : نفح الطيب من غصن الأندلس الرطيب للمقري

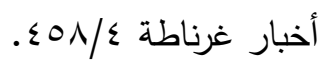

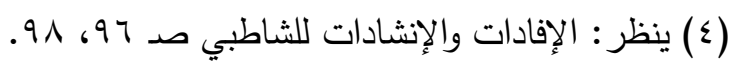

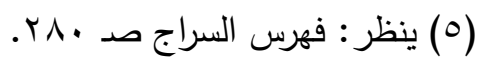

$$
\begin{aligned}
& \text { (7) ينظر : الإفادات والإنشادات صـ } 91 .
\end{aligned}
$$


حوليت كليت اللغت العربيت بإيتاى البارود (العدد الثاني والثلاثون - المجلد الرابع) وقد أثني علي ابن الفخار (ابن حذلم) حين وقف علي قبره في يوم عيد قائلاً: -

أبا جدث قد أحرز الشرف الخضا بأن صار مثوي السـيد العـالم الأرضسي عجبـت لـا أحرزتسه مـن معسارف و شـتي فعـال لم تـزل تعمـر الأرضـا.

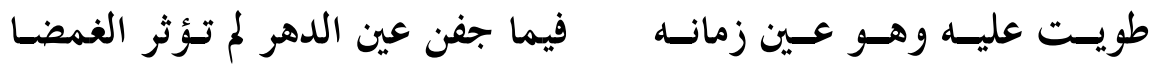
فحياك من صوب الحيـا كـل ديسة تسديم لـه في الجنسة الرفـع و الحفضـا. فها نخن في عيد الأسسي عنسد قـبر وقـوف لنقضسي مسن عيادتسه الفرضـا.

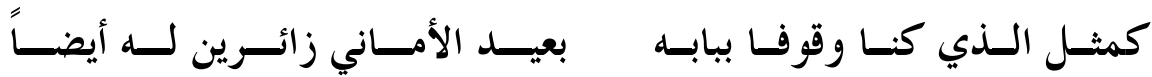

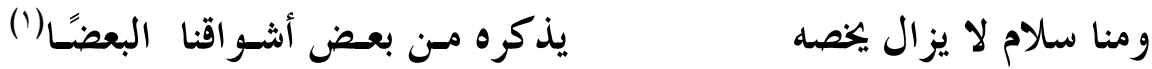
ورثاه أيضـا: محمد بن عبد الله اللوشي بقصيدة من واحد وعشرين بيتا، أوردها لسان الدين بن الخطيب(r) ضمن ترجمته لابن الفخار •

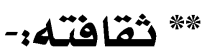

كان ابن الفخـار ذو ثقافـة واسعة، متتوعـة، بخاصـة في علم النحو، حيث بلغ الغاية القصوي في هذا العلم التي لا مطمح لأحد وراءها، (فقد كان يتفجر بالعربية تفجر البحر، ويسترسل استرسـال القطر ، وقد خالطـ لحمسه ودمه، لا يشكل عليه منها مشكل، ولا يعوزه توجيه، ولا تشذ عنه حجة، جدد بالأندلس ما كان قد درس من لدن وفاة أبي علي الشلوبين، وكان لله مشاركة في غير صناعة العربية من: قراءات، وفقه، وعروض وتفسير)(ّ). هكذا قال لسان الدين بن الخطيب.

(1) ينظر هذه الأبيات في نفح الطيب من غصن الأندلس الرطيب للمقري /

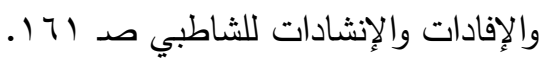

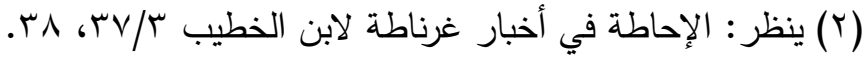

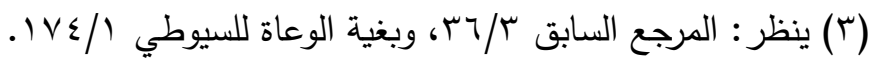




\section{دراسة موازنة بين منسجي الزجاجي وابن الفخار في تترح الجمل}

حوليت كليت اللغت العربيت بإيتاى البارود (العدد الثاني والثلاثون - المجلد الرابع)

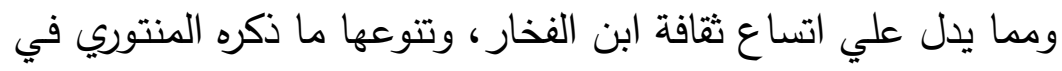
برنامجـه من روايـة ابن الفخار للكثير من كتب العلم من طريقه، في فنون

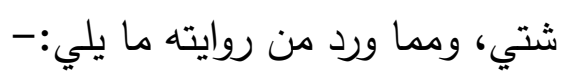
ا - كتاب المفردات لأبي عمرو الداني (').

r- كتاب إيجاز البيان في قراءة ورش لأبي عمرو الداني(؟).

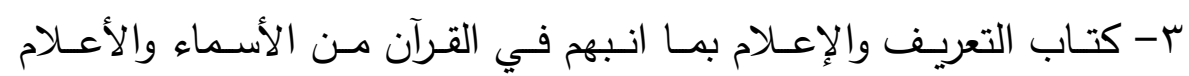
لكلأستاذ أبي زيد السهيلي (). ع - كتاب التقصي لما في الموطأ من رواية يحيي بن يحيي الليثي من حديث

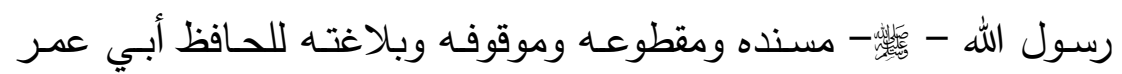

يوسف بن عبد الله بن عبد البر النمري(اء).

ه- كتاب الرسالة للشيخ أبي حمد بن عبد الله بن أبي زيد القيرواني (ْ).

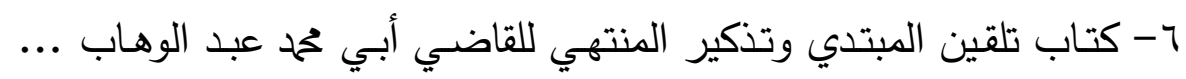
البغدادي.) (ج)

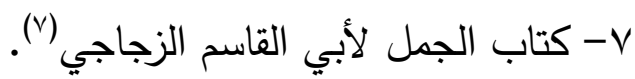
^- كتاب الكافي لأبي عمر يوسف بن عبد الله بن عبد البر النمري(^). 9- الكراسة المنسوبة لأبي موسي الجزولي (9).

$$
\begin{aligned}
& \text { (1) ينظر : برنامج المنتوري صـ ب. }
\end{aligned}
$$

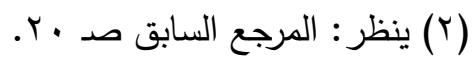

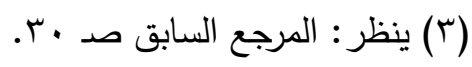

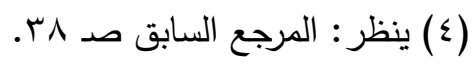

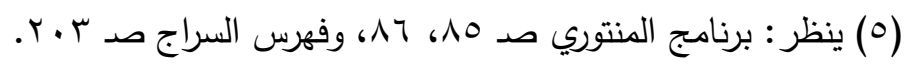

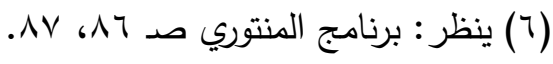

$$
\begin{aligned}
& \text { (V) }
\end{aligned}
$$

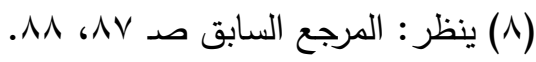

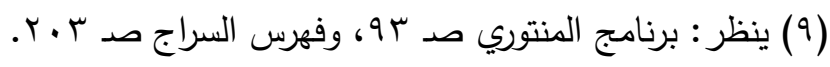




\section{دراسة موازنة بين منسجي الزجاجي وابن الفخار في تترح الجمل}

حوليت كليت اللغت العربيت بإيتاى البارود (العدد الثاني والثلاثون - المجلد الرابع)

• ا- برنامج الأستاذ أبي إسحاق إبراهيم بن أحمد بن عيسي الغافقي (1).

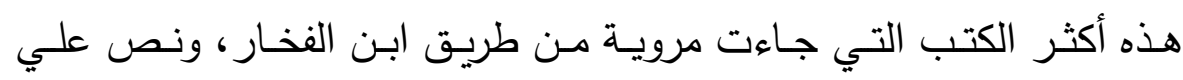
أسمائها المنتوري في برنامجه.

وهنـاك كثير من أسـاء المؤلفين الذين نص علي أسـائهم دون أن

ينص علي أسماء مؤلفاتهم، وهي أيضا مروية من طريق ابن الفخار، منها:-

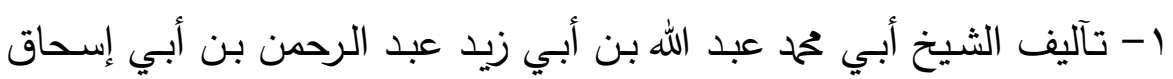

سعد بن بلال النفزي القيرواني المالكي، وهي نحو من عشرين تأليفاً(؟).

ب- تآليف الأديب أبي الحسن سـلام بن عبد الله بن سـلام الباهلي الأشبيلي

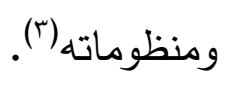

ب- تآليف الإمام أبي الحسن علي بن حمه بن عبد الملك بن يحي بن إبراهيم بن يحي بن القطان الحميدي القرطبي (؛).

ع - تآليف القاضي أبي عبد الله حمح بن عيسي بن حمد بن أصبح بن المناصف الأزدي القرطبي ومنظوماته.

ه- تآليف أبسي العبـاس أحمد بـن عبد المـؤهن بـن موسـي الشريشـي شـارح المقامات.

ج- تآليف القاضي أبي العباس أحمد بن حمد بن علي بن جوهر الليثي (॰). V- تآليف الخطيب أبي الحسن علي بن أحمد بن عبد الله بن خيره. ^- تآليف القاضي أبي عبد الله ححم بن علي بن خضر بن هوزن بن عسكر بن الغساني المالقي. 9- تآليف الخطيب أبي عبد الله حمد بن عبد الله بن قاسم.

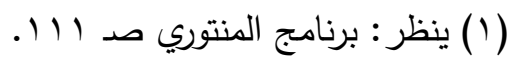

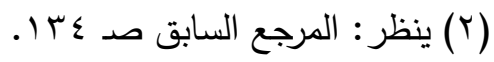

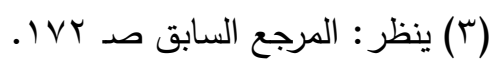

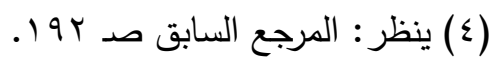

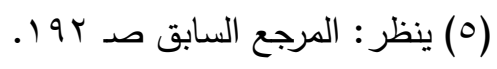


حوليت كليت اللغت العربيت بإيتاى البارود (العدد الثاني والثلاثون - المجلد الرابع)

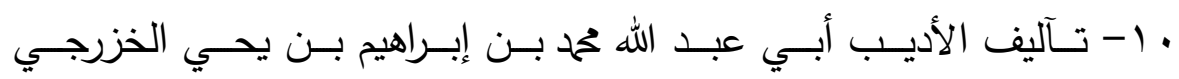

$$
\text { ومنظوماته (') - (1) }
$$

1ا- آليف القاضـي أبسي الحسن ظـاهر بـن علي بن عبد الرحمن السـلمي

$$
\text { الجزيري المراكثي. }
$$

ب ا - تآليف القاضي أبي العباس أحمد بن خحم بن عمر اليحصبي الموروي. ب ا- تآليف الأستاذ أبي عبد الله حمد بن أيوب حمد بن وهب بن حمد بن خحمد بن

$$
\text { نوح الغافقي (r). }
$$

ع ا - تآليف الثيخ أبي الحسن علي بن عبد الله المتيوي شارح الرسالة. ه - تآليف القاضي أبي عبد الله حمد بن الحسن بن عمر بن المحلي الفهري ومنظوماته.

7 ا - تآليف الثـيخ أبـي العباس أحمد بـن يوسف بـن أحمد بـن يوسـف بـن إبراهيم بن أحمد بن خلف بن الحسن بن الوليد السلمي المعروف بابن

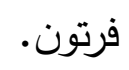

V ا - تآليف المحدث أبي علي حسن بن علي بن حمد بن القطان الحميري وهي عشرون مؤلفاً(). هذه أكثر المرويات التي رويت من طريق ابن الفخار ، وذكرهـا المنتوري في برنامجهه وتدل علي تتوع ثقافته بخاصـة في: القراءات، والفقه، والعروض، والتفسير ، مـ العلم أن هذه المرويات ليست كل ما كان يرويه ابن الفخار •

وذكر السراج أيضا في (فهرسه)(ء) أن ابن حياتي حمد بن علي الغافقي قرأ علي ابن الفخار القرآن بالقراءات السبع في ثمان ختمات، لكل إمام ختمـة، إلا نافعـا المدني فإنـه قرأ لـه ختمتين بروايـة ورش وقـالون عنـه، بمـا تضـــه

$$
\begin{aligned}
& \text { (1) ينظر : برنامج المنتوري صد سو ا. }
\end{aligned}
$$

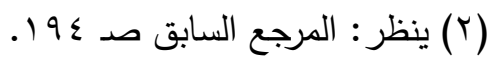

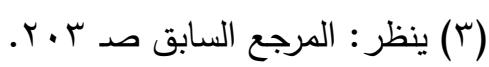

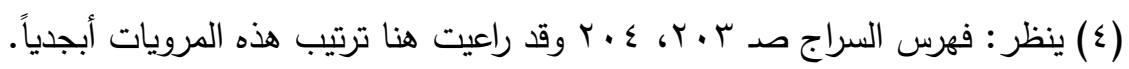


حوليت كليت اللغت العربيت بإيتاى البارود (العدد الثاني والثلاثون - المجلد الرابع)

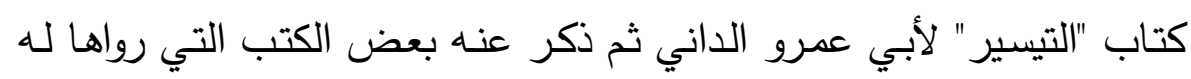
كلها أو بعضها ومنها:ا - الأحكام لعبد الحق الأشبيلي. r- إيضاح الفاسي. ب - برنامج الأستاذ أبي إسحاق الغافقي. ع -برنامج الأستاذ أبي الحسن بن أبي الربيع جمع تلميذ ابن الشاط. 0- تصريف أبي عثمان المازني، تصنيف أبي الفتح بن جني.

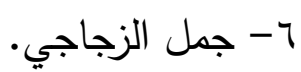
- - الحماسة للأعلم. - v ^- رسالة الإمام أبي القاسم القشيري. 9- سنن أبي داود. • ا - الثمائل للحافظ عيسي الترمذي. 11 r ا - فصيح ثعلب.

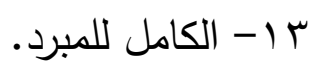
ع ا - كتاب سيبويه. 1 - النوادر لأبي علي البغدادي. وأغلب الظن أن هذه المرويات ليست كل ما كان يرويه ابن الفخار ، فإن هناك كتباً أخري أوردها في شرحه، والغالب أنه رواها أيضاً. * أساتذتهـتلقي ابن الفخـار علوم اللغـة،و القراءات، والفقه، والعـروض والتفسير علي مجموعة من العلماء والشيوخ، من هؤلاء:-ا- إبراهيم بن أحمد بن عيسي بن يعقوب، أبو إسحاق الغافقي.

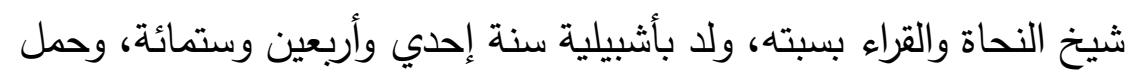
صغيراً إلي سبته، وقرأ بالروايات علي أبي بكر بن شبلون، وقرأ علي ابن 


\section{دراسة موازنة بين منسجي الزجاجي وابن الفخار في تترح الجمل}

حوليت كليت اللغت العربيت بإيتاى البارود (العدد الثاني والثلاثون - المجلد الرابع) أبي الربيع، وتقدم في العربية، وساد أهل المغرب فيها، وسمع الحديث من محهد بن جرير صاحب ابن أبي جمرة ومن أبي عبد الله الأزدي، له: " شرح الجمل وغيره، توفي سنة عشر وسبعمائة وقيل: خمس عشرة وسبعمائة،

$$
\text { وقيل: ست عشرة وسبعمائة "('). }
$$

ب- أبوعبد الله حمد بن عمر بن ححم بن عمر بن رشيد الفهري السبتي، خطيب غرناطة، بالمسـد الأعظم، توسـع في الروايـة، وذهب في ذلك إلي أبعد غاية، كان من أهل المعرفة بعلم القراءات وصناعة العربية وعلم البيان والعروض والقافية، كان أديبا بليغاً، قرأ بسبته علي ابن أبي الربيع، وقيد تقييداً حسناً علي كتاب سيبويه، وقرأ علي غيره من أهل المشرق والمغرب

$$
\text { توفي سنة إحدى وعشرين وسبعمائة(r). }
$$

ب- قاسـم بـن عبد الله بـن محمد الأنصـاري المعـروف بـابن الثـاط، يكني أبـا القاسـم، والشـاط اسـم لجـده ، قرأ بسـبته علم الأصـول والفـرائض، مقـدم موصوف بالإمامـة، موفور الحظ من الفقه، حسن المشاركة في العربية،

له نظر في العقليات، توفي سنة ثلاث وعشرين وسبعمائة (r). ع - أبو عبد الله محهد بن علي بن هاني اللخمي السبتي، كان فقيهاً محدثاً عارفاً بالعربية، قيد علي كتاب مالك تقييداً حسناً، كان فريداً في سمو الهمة، له تآليف مفيدة، أطال ابن الخطيب في الثناء عليه، توفي سنة أربع وثلاثين

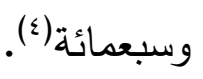

0- عبد المهيمن بن حمح بن عبد المهيمن بن حمحد بن علي بن خحمد بن عبد الله الحضرمي أبو خحم، لـه الفتح المعلي في علم العربية، والمشـاركة الحسنة في الأصلين، والإمامة في الحديث، والتبريز في الأدب والتاريخ واللغات

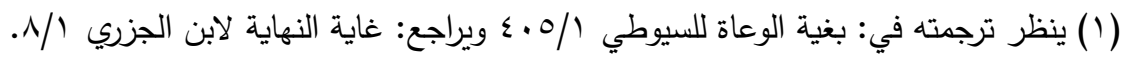

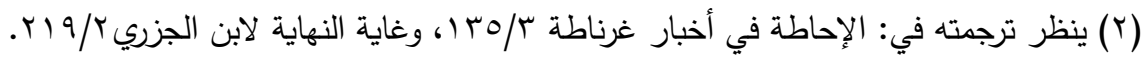

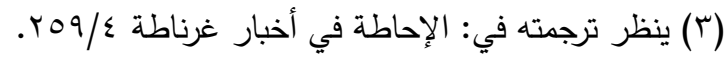

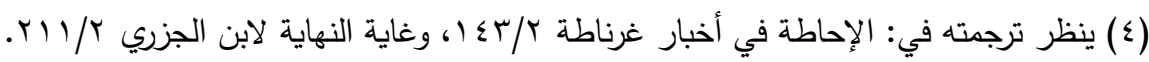




\section{دراسة موازنة بين منسجي الزجاجي وابن الفخار في تترح الجمل}

حوليت كليت اللغت العربيت بإيتاى البارود (العدد الثاني والثلاثون - المجلد الرابع) والعـروض، كثيـر الاجتهـاد والملازمـة والتفـن والمطالعـة، مقصـورا علي الإفادة والاستفادة إلي أن تولي كتابة الإنشاء فلم يفضل من أوقاته ما يسع الأشغال، موصوفا بالنزاهة والصدق، رفيع الرتبة، متصل الاجتهاد والتقييد قرأ علي أبي جعفر بن الزبير ، وأبي بكر بن عبيدة وجماعة، وروي عن ابن رشيد وابن أبي الربيع.....وخلق، وأجاز لله مالك بن المرحل وغيره ومن المشرق أبو حيان والدمياطي وخلق، وروي عنه ابن مرزوق، مات بتونس في الطاعون العام سنة تسع وأربعين وسبمعائة('). ج- حمح بـن عبد المنعم الصـنهاجي الحميري أبو عبد الله السبتي، كان من صدور الحفاظ، لم يستظهر أحد في زمانسه من اللغـة مـا استظهره ؛ آيـة تتلي ومثالا يضـرب، قائمسا علي كتاب سـيبويه يسـرده بلفظله، صـدوق اللهجة، سليم الصدر ، تام الرجولية، عابداً، صالحاً، كثير القرب والأوراد، قرأ كثيـرا علـي أبـي القاسـم بـن الثـاطر ، ولازمـه وانتفـع بـه قـال إسـحاق الغـافقي: وكان مشـاركاً في الأصـول، مالزمـاً للسـنة، يعـرب أبداً كلامـه طبقة في الشطرنج، توفي سنة خمسين وسبعمائة(؟). ومن شيوخ وأساتذة ابن الفخار أيضا كما ذكر لسان الدين الخطيب(r)، ولم

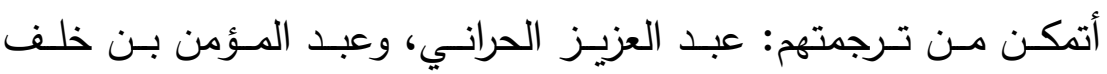
التونسي، وأبو العباس الحسيني، وصفه ابن الخطيب بأنه مقرى فاضل، وأبو عبد الله بن القرطبي، وصفه ابن الخطيب بأنه قاضٍ. وغير ذلك من الشيوخ والأساتذة الذين تتلمذ عليهم ابن الفخار .

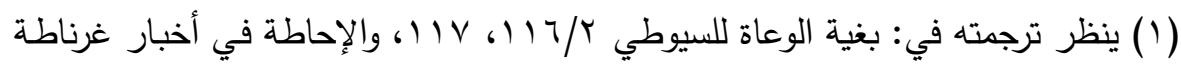
$.11 / \varepsilon$

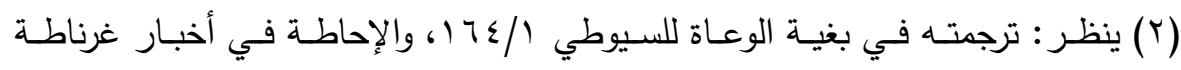

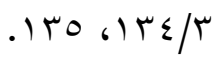
(T) ينظر: الإحاطة في أخبار غرناطة لابن الخطيب r/ Tr، 191، 199. 
تتلمذ علي يد ابن الفخار الكثير من العلماء الأجلاء الذين شُهد لهم بالفضل في العلم وقد تتوعت علومهم في جوانب شتي، وقل في الأندلس مَنْ لم يأخذ عنه، لذلك اقتصر علي ترجمة بعض تلاميذ ابن الفخار وهم:-

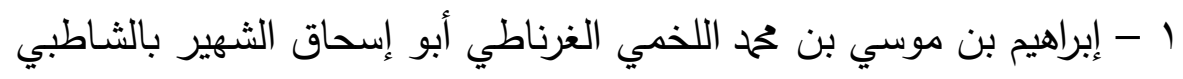

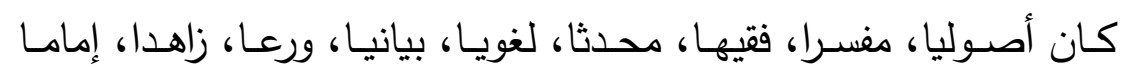
مطلقا، بحاثا، جدليا، بارعا في العلوم، أخذ عن ابن الفخار ولازمة حتي

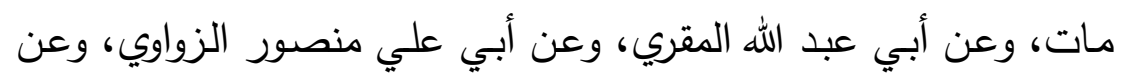
أبي عبد الله البلنسي، وغيرها، شرح ألفية ابن ماللك شرحاً لا نظير له، وله اله اله

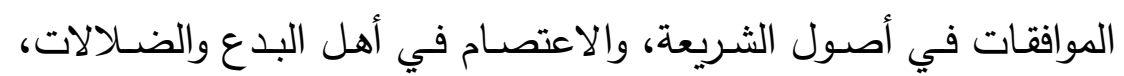
وكتاب الإفادات والإنشادات، توفي سنه تسعين وسبعمائة(1). r - أبو جعفر أحمد بن أبي سهل بن سعيد بن أبي سهل الخزرجي، من أهل

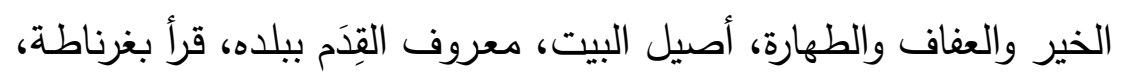
ولازم الأستاذ ابن الفخار ، ولي القضاء ببلدة الحمة ثم بمالقة وذكر لسان الدين بن الخطيب أنه ما زال حيا حين تآليف الإحاطة(r). r - أحمد بن يوسف بن مالك الغرناطي أبو جعفر الأندلسي، رفيق ححمد جابر الأعمي شارح الألفية، وهما المشهوران بالأعمي والبصير ، قدم القاهرة، ولقي لني

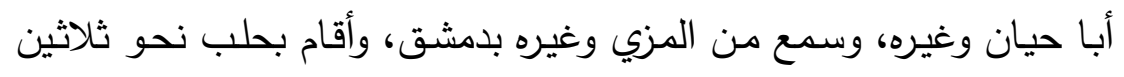

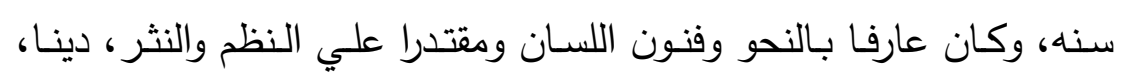
حسن الخلق، كثير التواليف في العربية وغيرها، شرح بديعية رفيقه، وأجاز لأبي حامد بن ظهيرة، مات سنة تسع وسبعين وسبعمائة(؟).

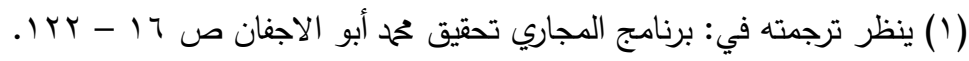

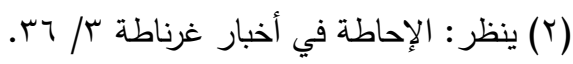

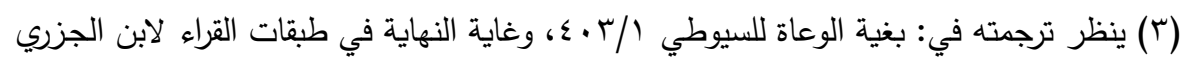


حوليت كليت اللغت العربيت بإيتاى البارود (العدد الثاني والثلاثون - المجلد الرابع)

ع - أبو حمد عبد الله بن أحمد بن حمد بن عبد الله بن عبد الرحمن بن يوسف

بن جزي الكلبي، مـن أهل غرناطسة ومن بيـت نباهـة وعلم، أبو الإمـام الثهير، قام علي فن العربية، مشاركا في فنون لسانية، قعد للإقراء ببلدة غرناطلة، ثم مستقلاً، ثم تقدم للقضـاء، أخذ عن والده، وقاضـي الجماعة الشريف أبو القاسم، وابن الفخار وغيرهم ('). ه - أبو سعيد فرج بن قاسم بن أحمد بن لب الغرناطي الثعلب، شيخ الأندلس وعي في زمانسه، ومفتيهـا، وخطيـب جـامع غرناطـة، جلس للتدريس بمدرسـة غرناطة بعد وفاة ابن الفخار بسته عشر يوما فقط، أخذ عن الخطيب أبي إسحاق بن أبي العاصي، وأخذ عن ابن الفخار علم العربية، وتوفي سنة ثلاث وثمانين وسبعمائة (r).

7 - أبو عبد الله حمح بن سـعد بن حمد بـن لب بن حسن بن حسن بن عبد الرحمن بن بقي بن مخلد، كان حسن العشرة، حسن المشاركة في فنون من قراءات وفقه ونحو، معروف الذكاء، جلس للتدريس بجامع الربض ثم بمسجد البكري بغرناطة، قرأ علي أبيه وعلي أبي عبد الله بن طرفه، وأبي عبد الله بن عامر، قرأ العربية علي ابن الفخار ، وجود القرآن بالقراءات السـبع، وقرأ علي أبـي عبد الله أيضـا فصـيح ثعلبـ، توفي سـنه إحدى وتسعين وسبعمائة)(")

- أبو عبد الله ححم بن علي بن أحمد بن حمد البلنسي الغرنـاطي، لـه علم بالعربية، ذاكراً لكثير من المسـائل، حافظـا متقنا، قرأ علي ابن الفخار وعلي غيره، ألف كتابا في التفسير متعدد الأسفار، واستدرك علي السهيلي

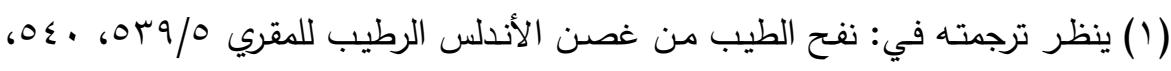

$$
\text { والإحاطة س/r }
$$

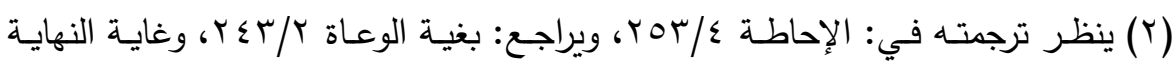

$$
. \wedge / r
$$




\section{دراسة موازنة بين منسجي الزجاجي وابن الفخار في تترح الجمل}

حوليت كليت اللغت العربيت بإيتاى البارود (العدد الثاني والثلاثون - المجلد الرابع) في أعلام القرآن، جرت له محنه مع السلطان ثم صفح عنه لحسن تلاوته القرآن، وتوفي سنة اثثتين وثمانين وسبعمائة('). 1 - محد بن علي بن حياتي الأستاذ المقرى النحوي المحقق، المنفرد بالإمامة في النحو، نشأ بغرناطة ولازم شيخ الجماعة ابن الفخار، وقرأ عليه بالسبع ثمـان ختمـات، انتقل إلـي فـارس ودرس بها، وهـو أول مَنْ أدخل كتاب المرادي علي ألفية ابن مالك إلي مدينة فاس بالمغرب، توفي سنة ثـان

وثمانين وسبعمائة، وقبل: إحدى وثمانين وسبعمائة(r). 9 - أبو عبد الله حمد بم ححم بن علي بن عمر بن إبراهيم بن عبد الله الكناني القيجاطي الأندلسي أستاذ مقرئ، عالم كامل، انتهات إليه مشيخة الإقراء في زمانه بالأندلس، قرأ علي جده أبي الحسن علي بن عمر، وقرأ علي سعيد بن لب، وعلي القاضي أبي البركات بن الحاج، وعلي ابن الفخار، وأخذ عنه قوانين ابن أبي الربيع(r). • 1 - أبو القاسم حمد بن حمد بن يوسف بن حمد بن علي الأنصاري، المعروف بابن الخشاب كان راوية عارفا بالوثائق، خطيبا بليخا كثير التلاوة للقرآن، وقوراً حسن السمت، مليح الثيبة، أخذ عن والده وخاله الأستاذ أبو عبد الله بن سلمون، وعن أبي الحسن القيجاطي، وأبي علي عمر بن عتيق، وابـن الفخـار ، وأجـازه المزنـي، وأبـو حيـان وغيـرهم في جماعـة يقـاربون أربعدائة شيخ (ع)

11 - أبن زمـرك حمح بن يوسف بـن ححم بـن أحمد بن ححم بـن يوسف بـن حمد الصريحي، من مفاخر الأندلس وعظمائها، كان جامعا لكثير من الصفات

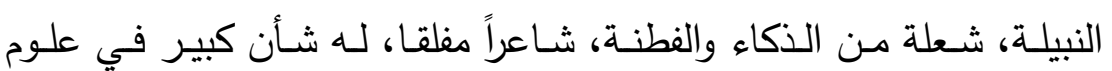

$$
\begin{aligned}
& \text { (1) ينظر ترجمته في: المرجع السابق ب/ه . }
\end{aligned}
$$

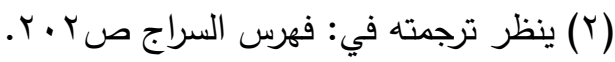

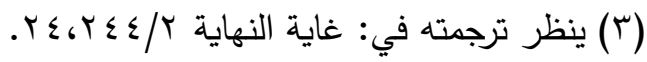

$$
\begin{aligned}
& \text { (ع) ينظر ترجمته في : فهرس السراج ص ابr - צr }
\end{aligned}
$$




\section{دراسة موازنة بين منسجه الزجاجي وابن الفخار في تترح الجمل}

حوليت كليت اللغت العربيت بإيتاى البارود (العدد الثاني والثلاثون - المجلد الرابع)

العربية والتفسير، مصاحبا للصوفية، ثم عاني الأدب فكان أملك بـه، ترقي إلي الكتابة عند ولد السلطان أمير المسلمين بالمغرب ابن سالم إبراهيم بن أمير المسلمين أبي الحسن علي بن عثمان بن يعقوب ثم عن السلطان ثم رجه إلي الأندلس بصـحبة صـاحب الأمـر بـه بعد رجوعـه إليـه من خَلْعِه،

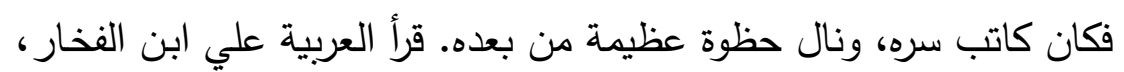
وعلي أبي سعيد بن لب واختص بالخطيب الفقيه ابن مرزوق وغيرهم كثير كان حيا حتي سنة اثنين وتسعين وسبعمائة('). r ا - أبو علي منصور بن عبد الله الزواوي، سكن غرناطة، فكان من مدرسي مدرسة غرناطة المشهورة، موصوف بخلال حميدة من عفة، وطهارة وعكوف علي ما يعينه، موجب لحق خصمه،، مثابر علي تعلم العلم وتعليمة، لا يري

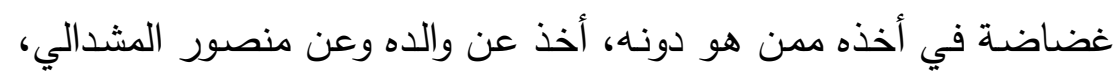
وأبي عبد الله الزواوي، وعبد المهيمن الحضري، ولازم ابن الفخار إلي وفاته، وكتب له بالإجازة والإذن له بالتحليق في موضعه بالمدرسـة بعده، كان حيا

\section{سنة سبعين وسبعمائة(r).}

با - يحي بن عبد الله بن يحي بن زكريا الأنصاري: متفنن في العلوم الثرعية، ولـه التقدم في علم الفـرائض والحسـاب، تـولي قضـاء عـدة مواضـع مـن الأندلس، ثم استعمل في النيابة عن قاضـي الحضرة، ثم استقصسي بمدينة وادي آش، وخطب بالمسجد الأعظم، أخذ إجازة عن الشيخ أبي إسحاق أبي إسـحاق بـن أبي العـاص، والخطيب أبي علي القرشي، وعن ابن الفخـار وغيرهم،(r) هؤلاء مَنْ ترجمت لهم من تلاميذ ابن الفخار ، ومن تلاميذه أيضـا ممن لم أترجم لهم خوف الإطالة:

$$
\begin{aligned}
& \text { (1) ينظر ترجمته في: الإحاطة r/ . .ب - ع 1. } \\
& \text { (Y) ينظر ترجمته في: الإحاطة س/ع rس - . rr. }
\end{aligned}
$$

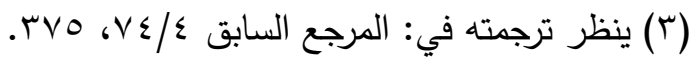


حوليت كليت اللغت العربيت بإيتاى البارود (العدد الثاني والثلاثون - المجلد الرابع) 1 - أبـو عبد الله عحمد بـن عمـر بـن يحـي بـن العربـي الغسـاني المعروف بـابن العربي (') (1)

ץ- أبو جعفر أحمد بن ححم بن علي بن يحي بن حمح بن مصسادف بن عبد الله(؟)

$$
\text { r - حبيب بن حمحد بن حبيب(r). }
$$

ع - أبو القاسم عبد الله بن يوسف بن رضوان بن يوسف بن رضوان البخاري(ء). ه - أبو بكر حمح بن أحمد بن زيد بن أحمد بن زيد بن الحسن بن أيوب بن حامد

بن زيد بن منخل الغافقي (ن).

7 - أبو عبد الله حمد بن عبد الله بن سعيد بن أحمد بن علي السلماني الشـهير

بلسان الدين بن الخطيب السلماني (ج). هؤلاء هم جميع من استطعت معرفتهم من تلاميذ ابن الفخار • وإلا فهم

$$
\text { أكثر من هذا العدد. }
$$

* آثاره وهؤلمْاته:-

لم أتمكن من معرفة أسماء مؤلفات ابن الفخار ، ولم يظهر لـي من

خلال ترجمـة أن لابن الفخار مؤلفات سوي مـا ذكره المنتوري في برنامجهـ(V) وهـو يرويها عن شـيخه أبـي عبد الله البلنسـي، وكذلك مـا ذكره السـراج في موهي فهرسه(^) - وقد سبق ذكرها - فلم يتعرض أحد ممن ترجموا لابن الفخار من

$$
\begin{aligned}
& \text { ( (1) يراجع في ترجمته: الإحاطة س/7 } 9 \text { (Y). }
\end{aligned}
$$

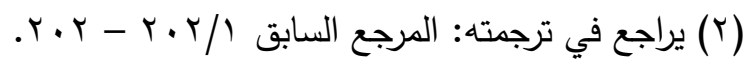

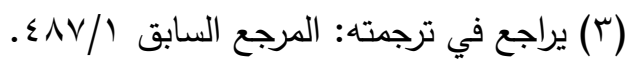

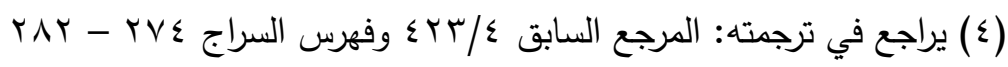

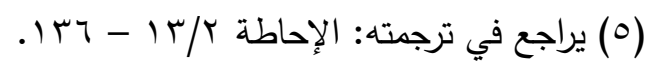

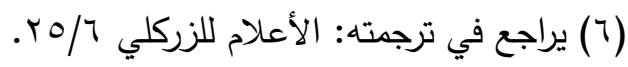

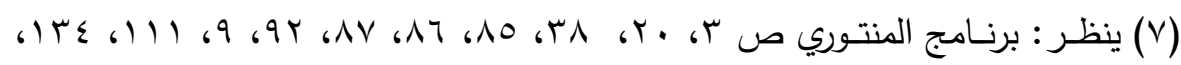

$$
\text { .r. }
$$

(^) 


\section{دراسة موازنة بين منسجه الزجاجي وابن الفخار في تترح الجمل}

حوليت كليت اللغت العربيت بإيتاى البارود (العدد الثاني والثلاثون - المجلد الرابع) ذكر أسماء مؤلفات له - بل إن المرويات التي رواها ابن الفخار بخاصـة في القراءات والفقه والعروض والتفسير هي ما تيسر لي معرفتها والوقوف عليها، دون معرفة لأسماء مؤلفات لله.

وقاته: - وقاته

اختلف المؤرخون في سنة وفاة ابن الفخار علي ثلاثة طرق: الطريق الأول: وسار فيه ابن الجزري، وهو أنه توفي في يوم الثلاثاء السادس من صفر سنة ثلاث وخمسين وسبعمائة(1 ). الطريت الثاني: وسـار فيه لسـان الدين بن الخطيب وهو أنها توفي في ليلـة الاثثين الثاني عشر من رجب سنة أربع وخمسين وسبعمائة (؟). الطريق الثالث: وسار فيه الثاطبي وهو أنه توفي في السادس عشر من رجب سنة ست وخمسين وسبعمائة (r).

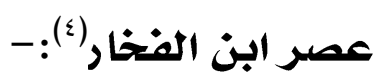

عاش ابن الفخار في ظل مملكة بني الأحمر في الفترة الواقعـة في أواخر القرن السـابع إلي عام أربعة وخمسين وسبعمائة، وهي أخصب فترات الثقافة العربية في تلك الأصقاع وقد شهدت تلك البقاع ساسـة لهح عناية كبيرة بالعلم وأهله، فهذا هو السلطان يوسف بن إسـاعيل وابنه السلطان ححم كانا يجريـان علي العلماء والمتعلمين جراية خاصـة بهم، ثم يجريـان جرايات أخري إضـافية لهؤلاء العلمـاء في حال قيامهم بأعمال أخري مـع قيامهم بالتدريس، فضلا عن أن إضافة لهؤلاء العلماء في حال قيامهم بأعمال أخري مع قيامهم بالتدريس، فضلا عن أن كثيرا منهم كانت له اهتمامات علمية، كمحه بن خحم بـن يوسف ثاني ملوك بني نصـر المتوفي سنة ا • لهـ الذي كان يقرض

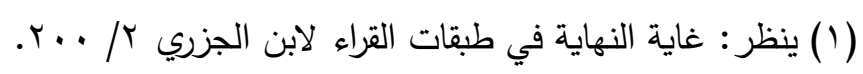

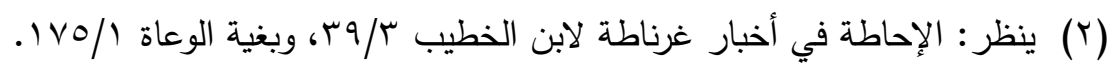

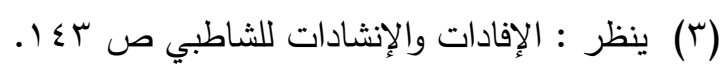

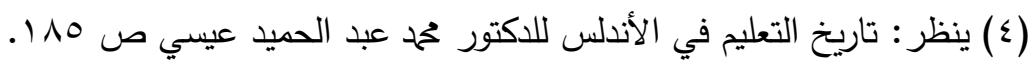




\section{دراسة موازنة بين منسجي الزجاجهي وابن الفخار في تترح الجمل}

حوليت كليت اللغت العربيت بإيتاى البارود (العدد الثاني والثلاثون - المجلد الرابع) الشـر ، وله توقيعات تشذ عن الإحصـاء، مدـا يدل علي أن لله تصـرف في

$$
\text { الأدب واهتماماً به (') }
$$

- وهذا ابنه محمد بن حمح بن حمح بن يوسف ثالث ملوك بني نصر كان لله شعر مستطرف من مثله بل يفضل به الكثير ممن ينتحل من الملوك الشعر . وهو الذي بني المسجد الأعظم بغرناطة الذي كان مناراً للعلم، وتقلم فيه حلقات التدريس في مختلف الفنون الثقافية، يدرس بـه نخبة من مدرسي غرناطة المشهورين إلي جانب مدرسة غرناطة أيضا(r). وإلي جانب عنايـة هذا الأمير بقرض الثـر ، فقد كان يصـي إليه ويشيب عليه، ويجيز الشعراء ويعرف مقادير العلماء (r).

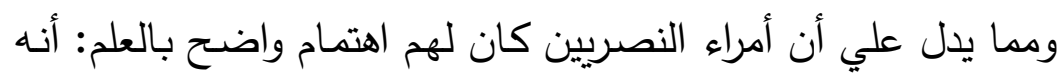
نشـأ في ظل دولتهم أعظم حدث علمي في الأندلسي وهو تشسييد المدرسـة النصـرية أو "اليوسفية" نسبة إلي مَنْ بناهـا وهو يوسف بن إسـاعيل الأول، الذي أمر بإنشائها عام • VO هـ، وهي تدل علي اهتمام بالغ بالعلم وأهله. ونتيجة لذلك الاهتمـام فإنه أسند القيام بإنشائها إلي أحد أكابر رجال الدولة في ذلك العصر وهو أبو النعيم رضوان النصري الحاجب، الذي وصفه ابن الخطيب بأنه حسنة الدولة النصرية، وبعد ذلك فإن هذا الحاجب قد سبب إليها الفوائد، ووقف عليها الرباع، وانفرد بمنقبتها، وجاءت نسيجة وحدها بهجة وظرفا وفخامة . وكان الطلبة يتوافدون عليها حتي من المسيحية(ء). وكان في هذه المدرسـة مدرسين هم نخبة من شيوخ العلم في ذلك الوقت كابن الفخار وكذلك شيوخه وتلاميذه الذين سبق ذكرهم.

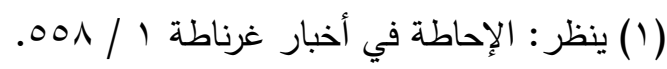

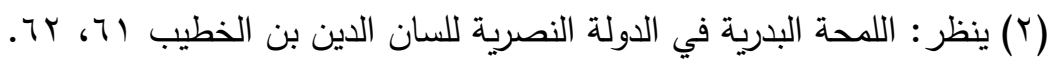

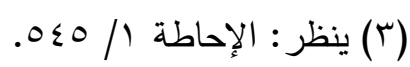

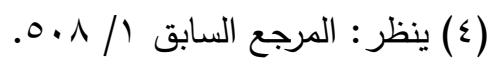




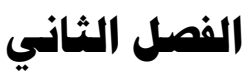

\section{ويشمل:}

(منهج ابن الفخار في "شرح الجمل" دراستّ موازنتش)

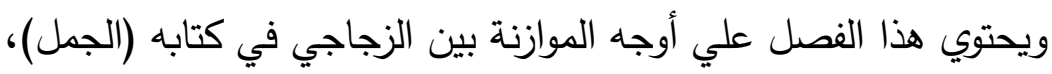

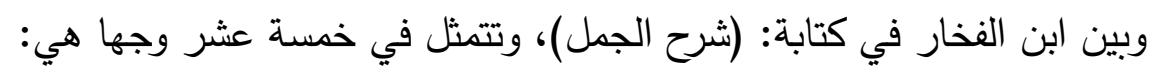
أولا: من حيث بداية تأليف الكتابين.

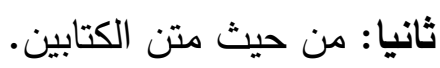

ثالثا: من حيث عرض المادة العلمية في الكتابين.

رابعا: من حيث ما يترتب علي المسائل النحوية والصرفية من أمور غيرهما عند

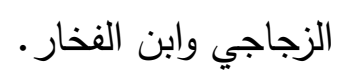

خامسا: من حيث التعريفات والحدود عند الزجاجي وابن الفخار •

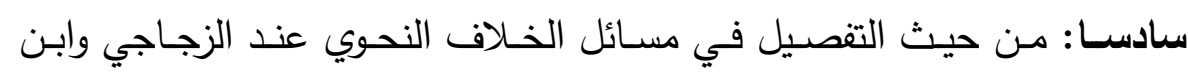

$$
\text { الفخار . (الفن }
$$

سابعا: من حيث التعليلات عند الزجاجي وابن الفخار .

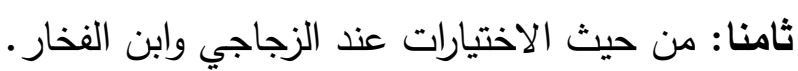

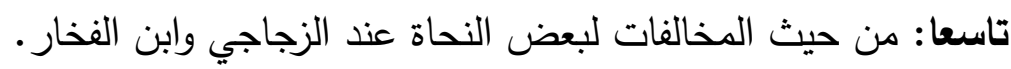
عاشرا: من حيث أسلوب الزجاجي وابن الفخار. حادي عشر: من حيث الحكايات التي وقعت للزجاجي وابن الفخار أو حضرها كل منهما.

ثاني عثر: من حيث الثواهد عند الزجاجي وابن الفخار . ثالـث عشـر: مـن حيث المذهب النحوي، وموقف الزجـاجي وابـن الفخـار من وانـ البصريين والكوفيين.

رابع عشر: من حيث اعتماد الزجاجي وابن الفخار علي المصادر • خامس عشر : من حيث موقف الزجاجي وابن الفخار من السماع والقياس.

$$
\text { - موقف ابن الفخار من الزجاجي (اعتراض ودفاع). }
$$

- - مواطن الاتفاق والاختلاف بين الزجاجي وابن الفخار (اتفاق وافتراق). 


\section{الفصل الثاني \\ منهج ابن الفخار في "شرح الجمل" \\ دراست موازنت}

من المعروف أن أبا القاسم الزجاجي كان من أفاضل الأئمة في النحو مواست

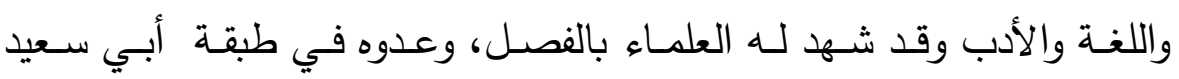

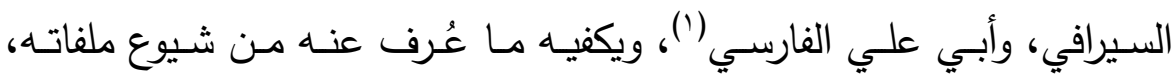
وعموم نفعها، وأن كتابـة (الجمل) كان عليـه المعول في مرحلـة من مراحل تاريخ النحو، حتي قيل فيه:-

(هو كتاب المصريين، وأهل المغرب، وأهل الحجاز ، واليمن، إلي أن

اشتعل الناس بـ "اللمع" لابن جني، و "الإيضاح" لأبي علي الفارسي) (؟).

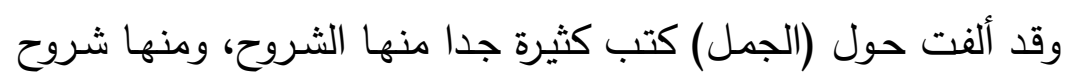
الشواهد، ومنها في التعقيب عليه أو التعليق، وقد بلغت شروحه في المغرب وحده "مائة وعشرين " شرحا ومن أهم هذه الثروح (شرح الجمل) لأبي عبد الله محمد بن علي بن أحمد بن حمد بن هذيل الخولاني، الإلبيري، المعروف بابن الفخار •

وقد حـاول ابـن الفخـار في (شـرح الجمـل) أن يحل مشكلات كتاب

(الجمل) ويستفيد من الشروح الأخرى التي سبقت شرحه، وذلك باختيار ما يراه

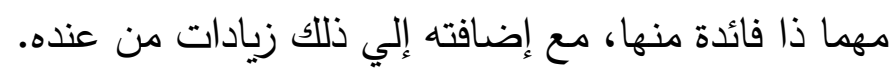
وقد ألف ابن الفخار كتابة (شرح الجمل) بصياغة جديدة، أهلته بأن إنهان

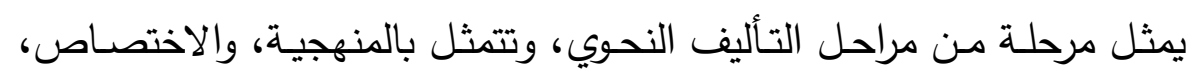
وتتسم بالميل الثديد؛ لقصد الإحاطة والشمول، علما بأن ابن الفخار في شرحه

(1) ينظر : نزهة الألباء لابن الأنباري ص

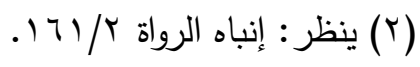


حوليت كليت اللغت العربيت بإيتاى البارود (العدد الثاني والثلاثون - المجلد الرابع) للجمل لم يبتعد كثيراً عن منهج الزجاجي في (الجمل)، بل اقتفي ابن الفخار أثر الزجاجي في نواح عديدة.

وهذا يقتضي منا عقد موازنة بين منهج الزجاجي في (الجمل) ومنهج

$$
\text { ابن الفخار في (شرح الجمل). }
$$

لنتبين من خـلال هذه الموازنـة أهم النقاط التي اتفق فيها كل منهـا، وكذلك أهم النقاط التي اختلف فيها كل منهما.

\section{ويمكن عقد تلك الموازنت علي النحو التالي:-}

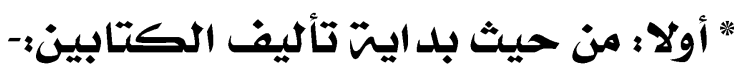

بدأ الزجاجي كتابة (الجمل) بالبسملة، والصلاة والسلام علي رسول الله -

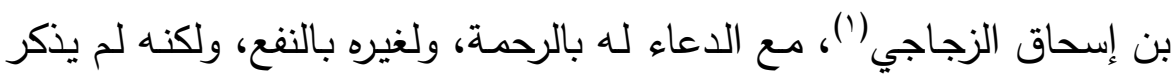
مقدمة يبين فيها السبب الذي من أجله ألف هذا الكتاب، ولم يذكر أيضا الاسم الذي سمي الكتاب بـه، ثم بدأ بعد ذللك بَعزضض متن الكتاب وأوله: (أقسـام

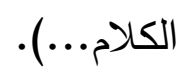

وقد حذا ابن الفخـار في (شرح الجمل) حذو الزجاجي، إلا أن ابن

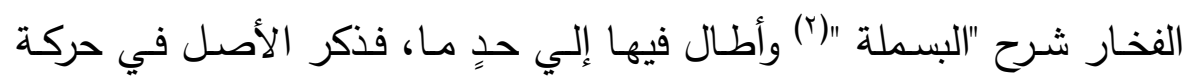
"الباء" في (بسم الله)، وهو الفتح، وذكر سبب ذلك، ثم ذكر سبب كسر "الباء" فيها. ثم ذكر أن في زيادتها وعدم زيادتها قولان، ثم ذكر اختلاف العلماء في وهي مـا تتعلق بـه إن كانت غير زائدة، ثم ذكر الاختلاف بين أهل البصـرة وأهل الكوفة في اشتقاق "اسم"؛ هل من: (س م و) كما هو مذهب البصريين أم من: (و س م) كما هو مذهب الكوفيين، ثم ذكر الأقوال في وزن لفظ الجلالة "الله" وذكر الأصل فيه، ومادته ثم ذكر اشتقاق "الرحمن الرحيم"، والاختلاف في

(1) لا يخلو أن يكون واضع الترجمة صاحب الكتاب أي: الزجاجي أو غير الزجاجي.

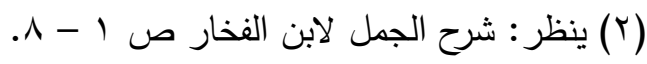


حوليت كليت اللغت العربيت بإيتاى البارود (العدد الثاني والثلاثون - المجلد الرابع)

أيهـهـا أبــن ومـذاهب العلمـاء في ذلـك، ثم ذكـر أقـوال النحـاة في إعـراب:

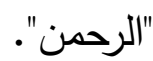

ثم شرح ابن الفخار بعد ذلك صيغة "التصلية " وهي: "الصلاة والسـلام

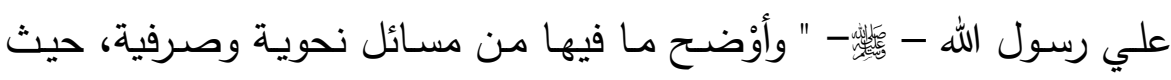
ذكر الاختلاف في عطف "الصسلاة والسـلام" بـالواو علي مـا قبلها، أو عدم عطفها علي ما قبلها وأوجه ذلك، ثم علق علي لفظ "حمد" فذكر وزنه ومعناه،

ثم علق علي لفظ " آل" فذكر أصله عند النحاة (1). ثم أوضح ابن الفخار بعد ذلك أن "الترجمة" أي ترجمة الزجاجي التي توجد في أول كتاب (الجمل)(r) يترتب عليها ثلاثة أسئلة الأول: حدها وتعبيره بلفظ "قال" عن المستقبل.

والثاخي: كنايته نمنه. والثالث: إعراب ما بعله ها.

ثم أجاب عن جميع هذه الأسئلة، وأوْضـح أن واضـع الترجمة إمـا أن يكون صساحب الكتاب أي الزجاجي، أو غيره، ووجه الإجابة عن كل منهما، وأوضح المقصود بالكنية بأبي القاسم ثم ذكر الأوجه الإعرابية الثلاثة في "عبد الرحمن". ثم ذكر الأوجه الإعرابية الأربعة في "ابن": ثم ذكر أن "إسحاق" غير مصروف لانضمام العلمية إلي العجمة، ثم أؤضح سبب لقبة بالزجاجي وهو أنه منسوب إلي شيخه أبي إسحاق الزجاج، ثم أوضح الأوجه الإعرابية فيه(r). * ثانيا : من حيث متن الكتابين : بالعودة إلي متن كتاب الجمل للزجاجي نجد أن الكتاب قد اشتمل علي ستة وأربعين ومائة بـاب، تناولت موضـوعات: النحو والصـرف والضـرورات الشعرية والأصسوات، وقد ذكرت هذه الأبواب (7 أ ) باب حسب ترتيبها في 


\section{دراسة موازنة بين منسجي الزجاجه وابن الفخار في تترح الجمل}

حوليت كليت اللغت العربيت بإيتاى البارود (العدد الثاني والثلاثون - المجلد الرابع)

كتاب (الجمل)، في المبحث الثاني (') من الفصل الأول عند التعريف بكتاب بإباى (الجمل)، وكان أولها: باب أقسام الكلام، وآخرها: باب: من شواذ الإدغام.

وقد حذا ابن الفخار في (شرح الجمل) حذو الزجاجي في (الجمل) من

حيث ترتيب هذه الأبواب، مـع شرح ابن الفخار لها شرحا تفصيليا لكن ابن الفخار في شرحه بدأ بباب أقسام الكام وانتهي بباب النسب(ז) أي: أن شرح ابـن الفخـار تـاول أربعـة وثـانين بابـا فقط أمـا بـاقي الأبـواب وعددها اثـان وستون باباً، وهي من أول باب ألف الوصل وألف القطع إلي آخر باب شواذ الادغام(ّ) والتي تناولها الزجاجي في (الجمل)، لم يتعرض ابن الفخار في شرحه إليها إلا جزء من باب التصريف جعله تحت عنوان: "باب منه آخر "(£) حيث شرح هذا الباب وحده وتتاول فيه: أوزان الأفعال الثلاثية المعتلة العين الصـحيحة الـلام، وتــاول اسـم المفعول من الثلاثي، ومـا يتعلق بـه، وأضـرب المزيد من الأسماء.

ثم ذكر فائدة في: متي يحمل الاسم علي الفعل في الإعلال رثم ذكر حكم اجتمـاع الواو والياء مـع سبق إحداهما بالسكون, وأخيرا ذكر فصـلا في كـون كـل واو بضـمه همزهـا جـائز إلا أن يكـون ضـمها إعرابـا أو لالتقــاء

ساكنين. (0)

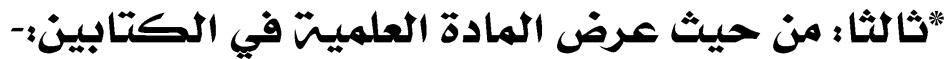

يعد كتاب (الجمل) للزجاجي هو المتن الذي جاءت عليه الشروح، أو

لتعليقات أو غيرهـا وقد جـاءت موضـوعاته في النحـو والصـرف والضـرورات

(1) ينظر : المبحث الثاني من الفصل الأول. (Y) هذه الأبواب في كتاب الجمل للزجاجي من صـ V V إلي صـ YoV وفي شرح الجمل

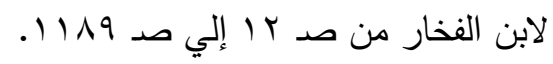

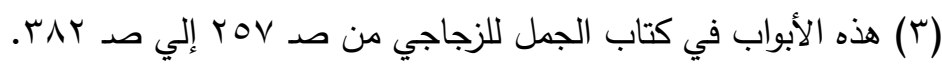

(ع) ينظر : شرح الجمل لابن الفخار ص . 119 - إلي ص 119

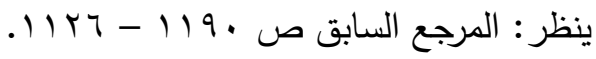


حوليت كليت اللغت العربيت بإيتاى البارود (العدد الثاني والثلاثون - المجلد الرابع) الشـعرية، والأصسوات، وقد قسـم الزجـاجي كتابـه (الجمـل) إلـي سـتة وأربعين ومائه بـاب -كمـا سـبق، وقد جاء تناولـه للموضـوعات مبني علي الإيجاز ، واختزال الكلمات، والاقتصاد في التعبير، مع قصد الإحاطة والشمول. وقد سلك ابن الفخار في (شرح الجمل) مسلك الزجاجي فجاء شرحه مقسما إلي أبواب أيضـا، إلا أن ابن الفخار كان لا يذكر نص ومست كتاب (الجمل) كاملا، بـل كان يذكر جزء من متن (الجمل) ثم يعقب ذلك بقوله: (إلي آخره)(')

أو (إلي آخر الفصل)(ז) ونحو ذلك. ثم يقوم بشرح مـا يتعلق بذللك النص؛ أي أنه كان يفصل في الشرح ما الشرح ما أجمله الزجاجي في المتن، إذن فكتاب (الجمل) للزجاجي كتاب مختصر ، ويعد كتاب (شرح الجمل) لابن الفخار من التآليف الطويلة التي شرحت هذا الكتاب. * وهذه الطريقة التي سار عليها ابن الفخار لم يخالفها إلا في أبواب عديدة فإنه كان لا يذكر فيها نص كتاب الجمل، كما في باب: "الاستغاثة"(r)،

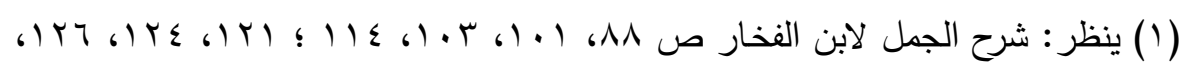

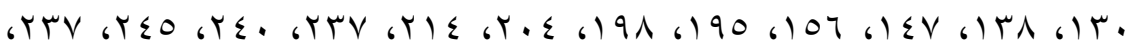

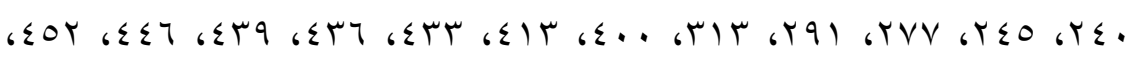

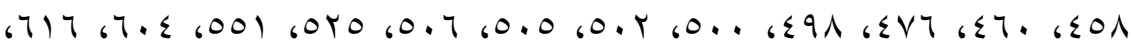

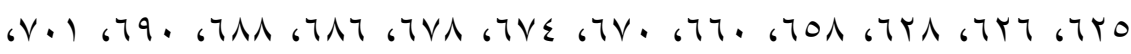

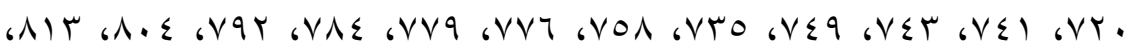

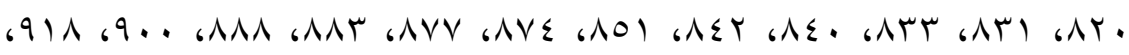
$6) \leqslant r 61 \cdots 969 V \cdot 690169 r r 69 r r$

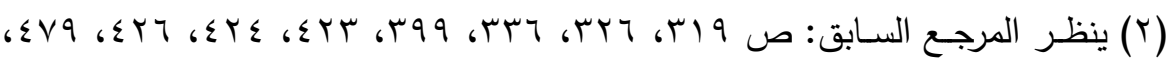

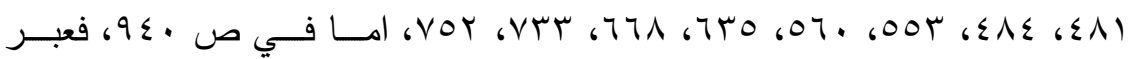

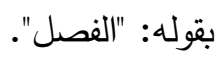

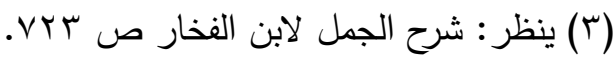




\section{دراسة موازنة بين منسجي الزجاجي وابن الفخار في تترح الجمل}

حوليت كليت اللغت العربيت بإيتاى البارود (العدد الثاني والثلاثون - المجلد الرابع)

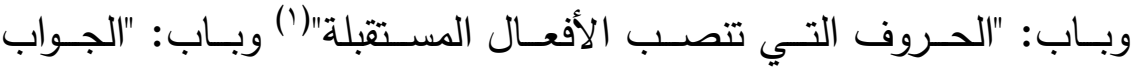

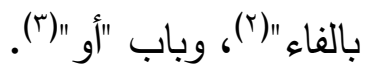

أما في باب: "مـا "(؛)، وباب: "تعم وبئس"() فلم يذكر في كل واحد من

$$
\text { البابين إلا نصا واحدا. }
$$

" وإذا كان الغالب علي ابن الفخار في (شرح الجمل) أنه كان يذكر جزء من

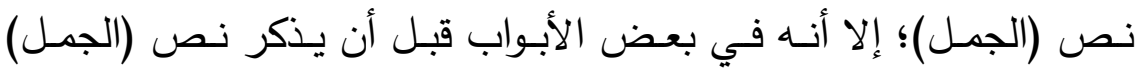
للزجاجي كان يقدم لتلك الأبواب بمقدمة قد تطول وقد تقصر ، وهذه المقدمة يتضمنها تعريف الموضوع الذي يريد شرحه، ثم يأتي بعد ذل بنص أبي القاسم الزجاجي فيشرحه، ومن الأبواب التي قدم لها بمقدمـة طويلـة بـاب:

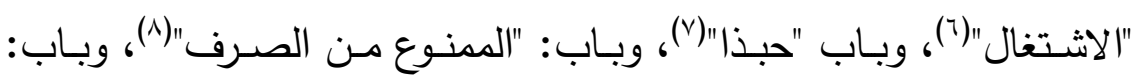

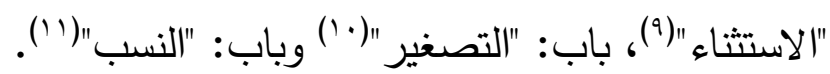

وكان لابن الفخار في عرض المـادة العلمية منهج وطريقة لم تكن لغيره من النحاة وهي: أنه كان كثيراً ما يذكر المسألة النحوية، ثم يعود إليها مرة أخري فيشرحها تحت عناوين أخري كثيرة فنراه يقول:-

$$
\begin{aligned}
& \text { (1) ينظر : الرجع السابق ص • • (Y) }
\end{aligned}
$$

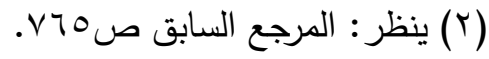

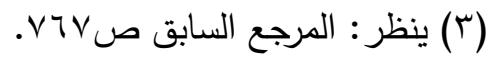

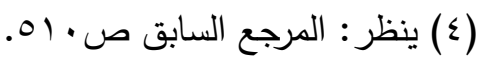

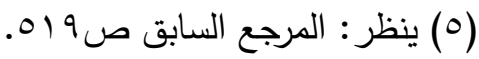

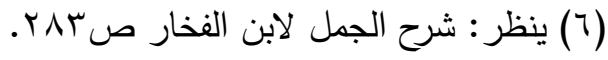

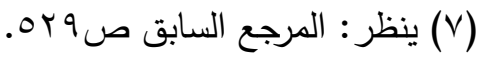

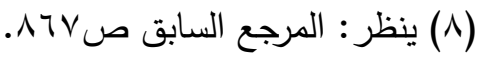

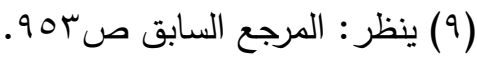

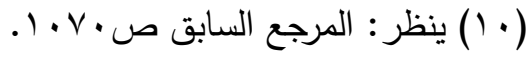

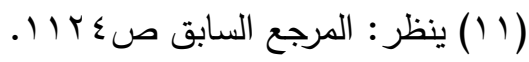




\section{دراسة موازنة بين منسجي الزجاجه وابن الفخار في تترح الجمل}

حوليت كليت اللغت العربيت بإيتاى البارود (العدد الثاني والثلاثون - المجلد الرابع)

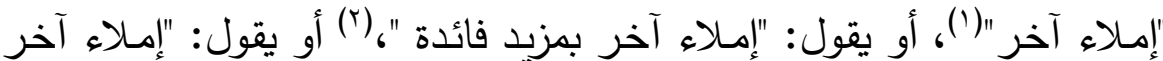

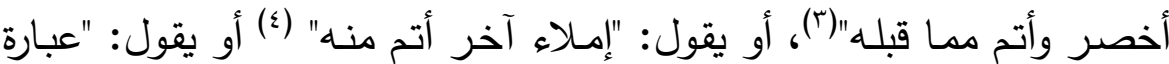

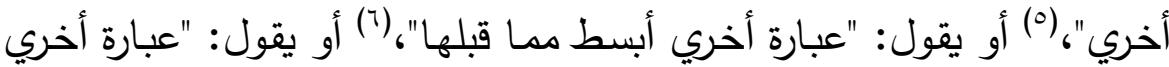

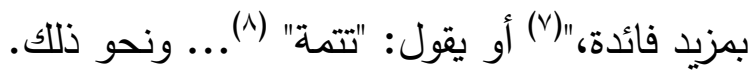
وكأن ابن الفخار شرح كتاب (الجمل) ثم عاد إليه مرات كثيرة، وفي كل مرة يضيف ما يراه إكمالا لما سبق شرحه.

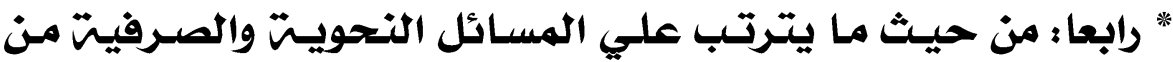
أمور غيرها عند الزجاجي وابن الفخار: كان الزجاجي في كتابة (الجمل) يذكر المسائل النحوية والصـرفية فقط، دون أن يذكر ما يترتب عليها من أمور أخري غير نحوية أو صرفية -

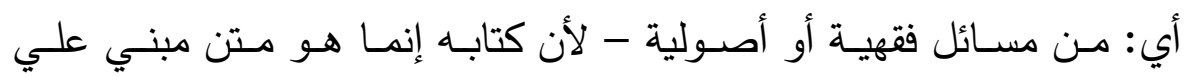

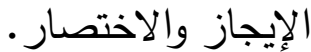

لكن ابـن الفخـار في (شـرح الجمل) كـان يـكر المســائل النحويـة

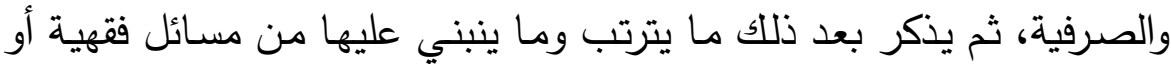

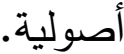
فمثال المسائل النحويت التـي ينبنـي ويترتب عليها حكـم فقهي

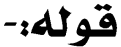

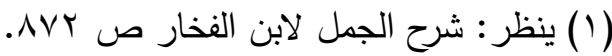

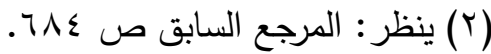

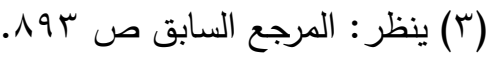

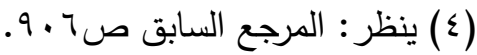

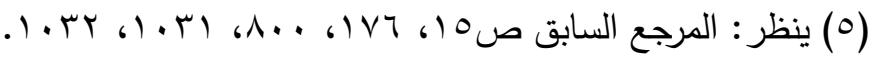

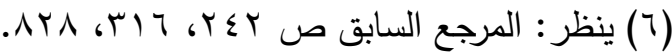

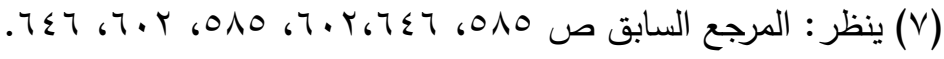

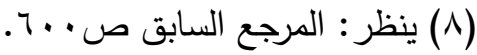


حوليت كليت اللغت العربيت بإيتاى البارود (العدد الثاني والثلاثون - المجلد الرابع) (لو أن شـهوداً شـهدوا فقـالوا: رأينـا العدو قتل زيـداً وأخـاه، فقيـل لهم: نُصُوا الثهادة علي ترتيب الفعل، فقالوا: قتل العدو زيداً ثم أخاه ، فالأخ علي هذا وارث لزيد. وكذلك بالفاء .

فـان قـالوه بـالواو، كـان ذلـك مجمـلا، فـإن مـاتوا قبـل ترتيـب المـوت

وتوقيته، لم يرث واحد منهما أخاه: لأن الميراث لا يكون بالثك)('). ومثال المسائل النحوين التي نظّر لها بمسائل فقهيتهأنه ذكر أن بعض النحاة منع عمل المبتدأ في الخبر من حيث إن المبتدأ إن كان رافعـا فاعلا فإنها يؤدي إلي إعمـال عامل في معدولين رفعـا نحو: "القائُ أبوه ذاهب"، فأبوه فاعل لـ "القائُ" و "ذاهب" خبر لـ " قائم" أيضـا، وكلاهما مرفوع بـ "قائم"، هذه حجة من منع ذلك. وقد أبطل ابن الفخار حجة المانع من حيث إن "قائم" رفع الفاعل، من حيث هو اسم فاعل لا من حيث هو مبتدأ، ورفع الخبر من حيث هو مبتدأ لا من حيث هو اسم فاعل، فعلي ذلك كان الرفعان من جهتين مختلفتين لا من جهة واحدة. هذا كان رد ابن

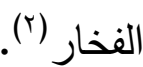

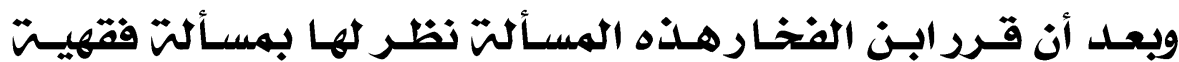

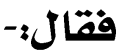

(وزَانُه الصلاة في الدار المغصوبة)(").

يعني أن الصلاة في الدار المغصوبة باطلة، وبطلانها ليس من جهة الصلاة نفسها، وإنما بطلت من جهة أخري هي: كونها في ذلك المكان. وهناك مسائل فقهية أخري (ء) فليرجع إليها مَنْ شاء.

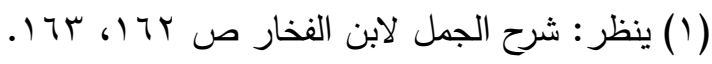

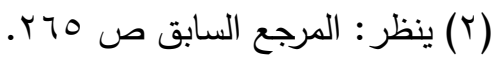

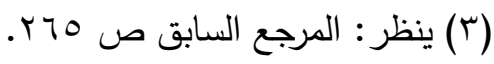

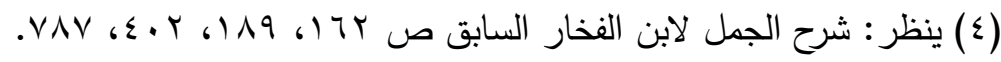


حوليت كليت اللغت العربيت بإيتاى البارود (العدد الثاني والثلاثون - المجلد الرابع) ولـم يتعـرض الزجـاجي في كتـاب (الجمـل) لشـيء مـن مسـائل أهـل الأصـول، بخـلاف ابن الفخار في ( شرح الجمل) قد تعرض لبعض مسـائل الأصوليين مثل قوله:-

(وليس بمستقيم ما يعتقده كثير من أهل الأصول من إطلاق القول من أن النكرة في سياق النفي تفيد العموم)(') وقوله: (ومن الناس من جعلها من من من مه باب الإعمال علي اعتقاد تعميم اللفظ المشترك)(r). * خامساء من حيث التعربمًات والحل ود عند الزجاجي وابن الفخار:كـان الزجـاجي في كتـاب (الجمـل) لا يبـدأ كل موضــوعاته بوضـح تعريفات. وحدود لها، بل اقتصر علي بعض الأبواب فوضع تعريفات لها مثل تعريفه للفعل بأنه: (ما دل علي حدث وزمان ماض أو مستقبل)(َ)، وتعريفة للحرف بأنه:(ما دل علي معني في غيره )(؟) وتعريفة للنكرة بأنها: (كل اسم شائع في جنسه لا يخص به واحد دون وتعريفة للحال بأنها: (كل اسم نكرة جاء بعد اسم معرفة قد تم الكلام

وتعريفة للترخيم بأنه: (حذف أواخر الأسماء الأعلام في النداء خاصة

تخفيفا)(V). (v)

$$
\begin{aligned}
& \text { (1) ينظر : شرح الجمل لابن الفخار ص سדr. } \\
& \text { (Y) ينظر : المرجع السابق ص (Y) }
\end{aligned}
$$

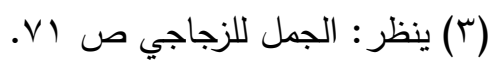

$$
\begin{aligned}
& \text { (ع) ينظر : المرجع السابق ص IV) }
\end{aligned}
$$

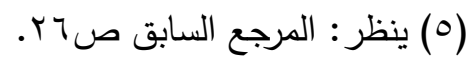

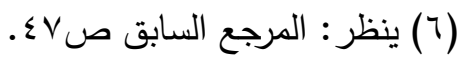

$$
\begin{aligned}
& \text { (V) ينظر : المرجع السابق ص اله (N) }
\end{aligned}
$$




\section{دراسة موازنة بين منسجي الزجاجي وابن الفخار في تترح الجمل}

حوليت كليت اللغت العربيت بإيتاى البارود (العدد الثاني والثلاثون - المجلد الرابع) وتعريفـة للتمييز بأنـه: (كل اسم نكرة جاء بعد عدد منون وفيه نـون

أونية تتوين)(')

وكذذلك عـرف: المنـدوب (r)، والمعـرب والمبني (r)، والمقصـور (§)،

$$
\text { والإمالة(0) وغيرها. }
$$

وهنـاك كثير من الأبـواب لم يضـع لهـا الزجاجي حدوداً أو تعريفـات

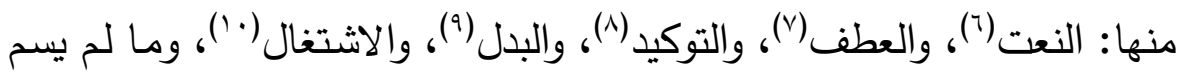

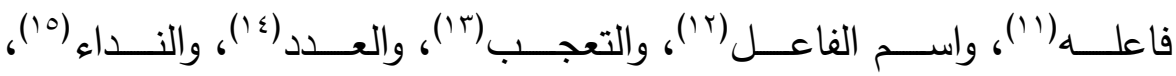

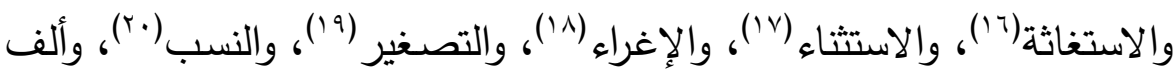

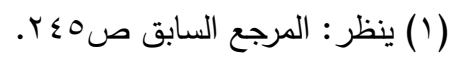

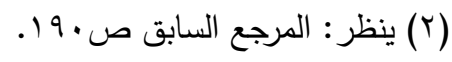

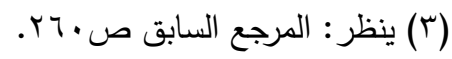

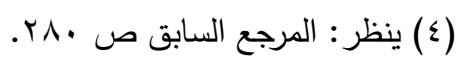

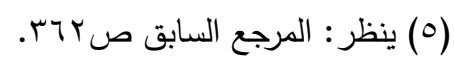

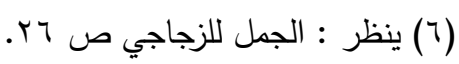

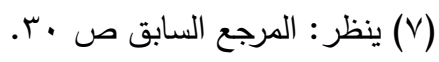

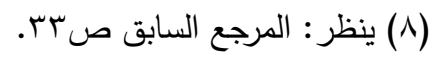

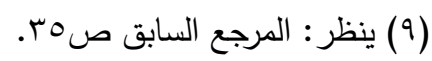

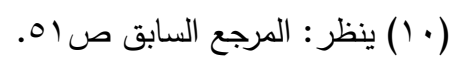

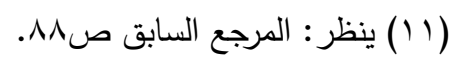

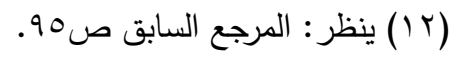

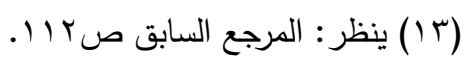

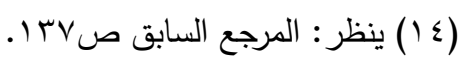

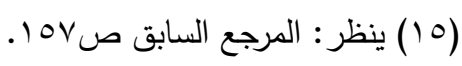

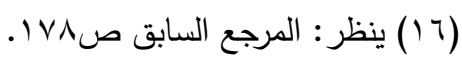

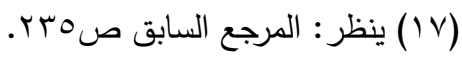

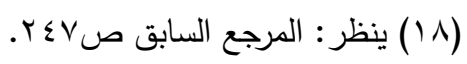

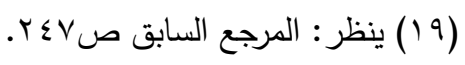

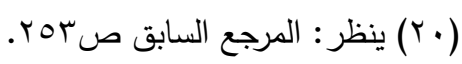




\section{دراسة موازنة بين منسجي الزجاجي وابن الفخار في تترح الجمل}

حوليت كليت اللغت العربيت بايتاى البارود (العدد الثاني والثلاثون - المجلد الرابع)

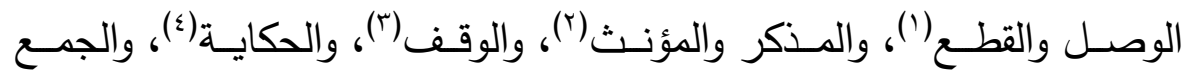

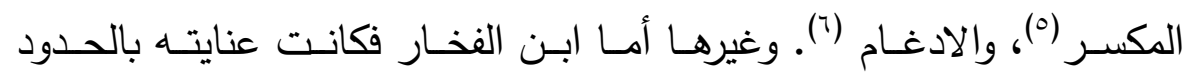

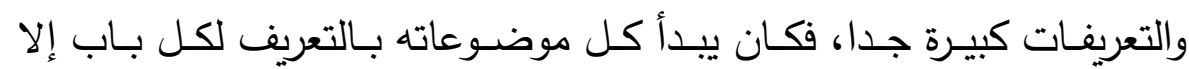

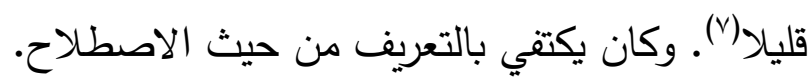

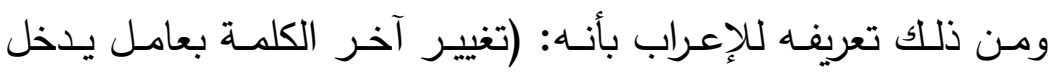

(ع) (^)

وتعريفة للتثنية بأنها: (ضم اسم إلي مثله.....)(9).

وتعريفة للفاعل بأنه: (كل اسم مرفوع تحقيقا أو تقديرا مسند إليه فعل إنه

أو ما في معناه مقدم عليه، غير مبني لمفعول)(·').

وتعريفـه للنعـت بأنـه: (الاسـم الجاري علي مـا قبله تحقيقا أو تقديرا

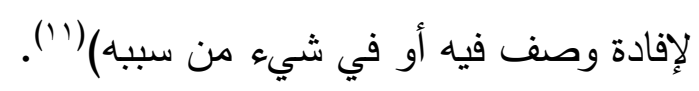

وتعريفه للعطف بأنه: (تشريك الثاني مع الأول في عامله بحرف من حروف

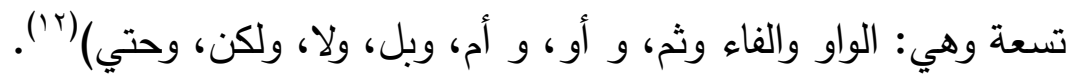

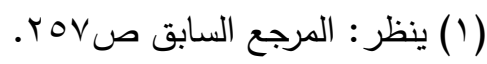

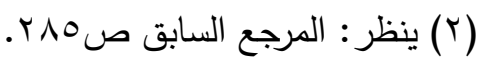

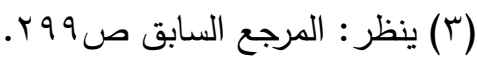

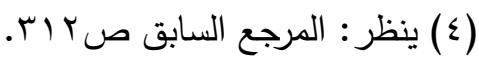

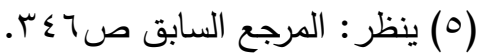

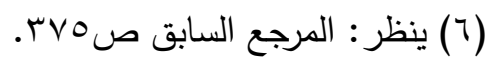

لأنه كان يري أن هذه الحدود لا تعطي معني دقيقا للمحدود. (V)

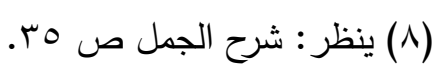

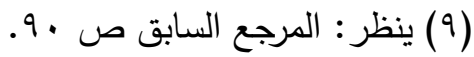

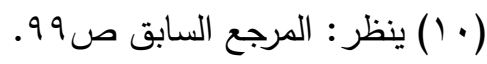

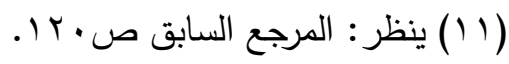

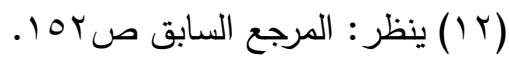


حوليت كليت اللغت العربيت بإيتاى البارود (العدد الثاني والثلاثون - المجلد الرابع)

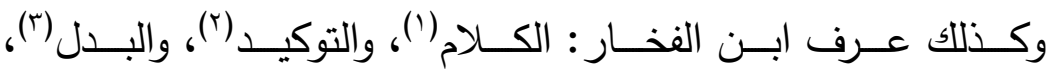

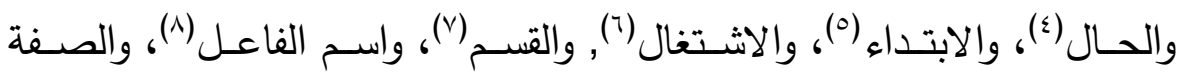

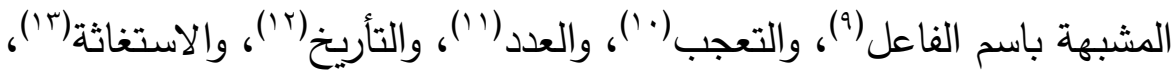

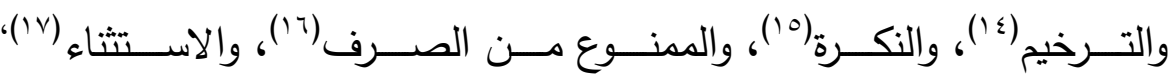

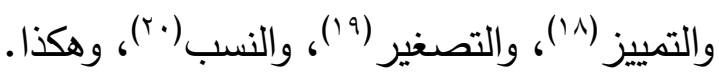

وكـان ابـن الفخـار أحيانـا يقدم للموضـوع بـكر تعريفـه مـن الناحيـة

اللغوية مثل قوله:

(1) ينظر : المرجع السابق صع (1، 0 1.

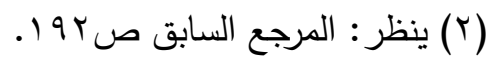

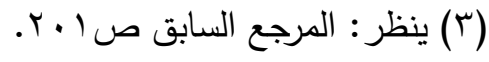

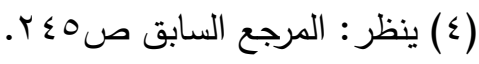

(0) ينظر : المرجع السابق ص آبץ.

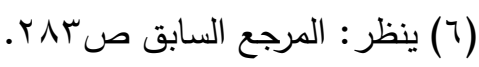

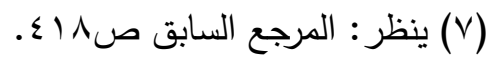

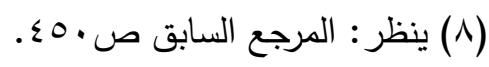

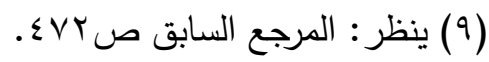

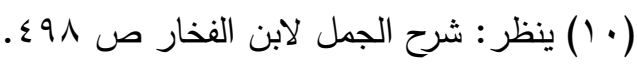

(1) (1) ينظر : المرجع السابق ص (1) (1).

(Y) (Y) (T)

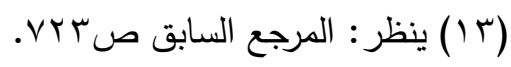

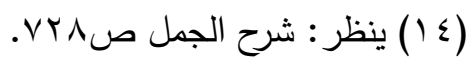

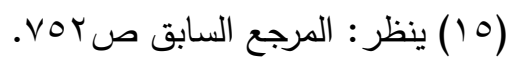

(7 (1) ينظر : المرجع السابق صد79. (19.

(IV) ينظر : المرجع السابق صـو (IV)

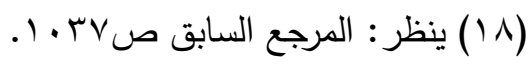

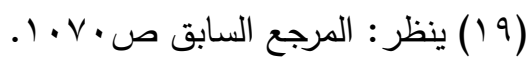

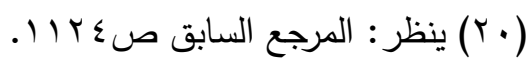




\section{دراسة موازنة بين منسجي الزجاجي وابن الفخار في تترح الجمل}

حوليت كليت اللغت العربيت بإيتاى البارود (العدد الثاني والثلاثون - المجلد الرابع)

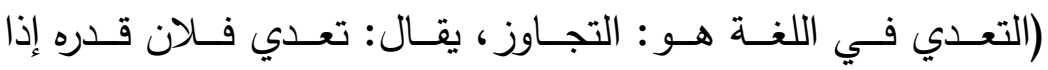

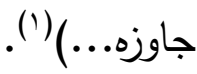
وقوله: (الترخيم في اللغة هو : التسهيل والتليين...)(؟). وقوله: الإغراء في اللغة هو : الإلزام والتسليط...)(َّ). ومع كل هذا فإن هناك أبوابا لم يحدها ابن الفخار مثل "مأ لمعاء لم يسم

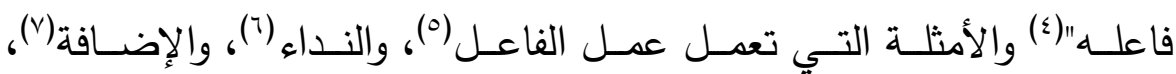
والندبة)(^)

وذلك لأنه كان يري أن هذه الحدود لا تعطي معني دقيقا للمحدود،

ولذللك قـال: (فَـن رام اقتـاص الأسـماء علي الاطـلاق بشبكة الحـد فقد رام محالا، إذ لا يتصـور اشتمال حد واحد علي حقيقة ومجاز ، فـلا يلزم إذا في حدود النحاة أن تكون كحدود المناطقة، وإنما غرضهم المقصود بما أمكن من العبارات، فما كان أقرب إلي المقصود كان الأخذ به أوْلي)(9).

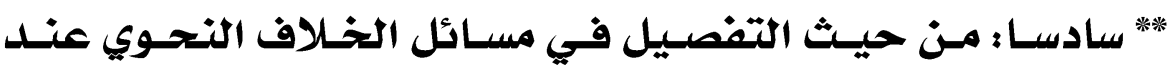
الزجاجي وابن الفخار:كـان الزجـاجي قلـيلاً مـا يـذكر مسـائل الخـافلاف النحـوي في كتابـة (الجمل)، وهناك مواضـع قليلة ذكر فيها مسـائل الخـلاف بين النحاة، وكـان أحيانا يذكر مسائل الخلاف فقط بين النحاة، وأحيانا يذكر مسائل الخلاف مع

$$
\begin{aligned}
& \text { (1) ينظر : المرجع السابق ص99/Y. }
\end{aligned}
$$

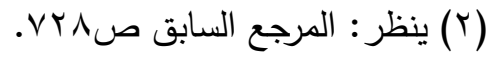

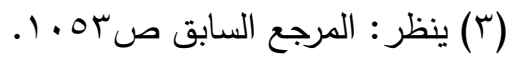

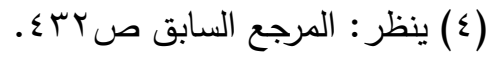

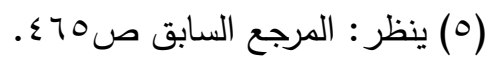

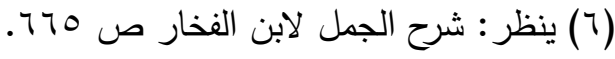

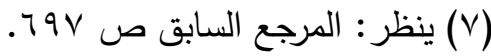

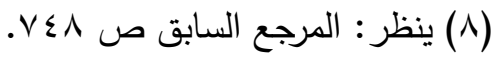

$$
\begin{aligned}
& \text { (9) ينظر : شرح الجمل ص آب. }
\end{aligned}
$$




\section{دراسة موازنة بين منسجي الزجاجي وابن الفخار في تترح الجمل}

حوليت كليت اللغت العربيت بإيتاى البارود (العدد الثاني والثلاثون - المجلد الرابع) ذكر الرأي الراجح ودليله، وأحيانـا يذكر مسـائل الخـلاف ويـكر الرأي الراجح دون الدليل ومن مسائل الخلاف التي ذكرها بين النحاة ما يلي:ا - الخلاف في فتح همزة " إنّ " وكسرها بعد اليمين (1). r - الخلاف فيما إذا كان الفعل غير متعد إلي مفعول هل يرد إلي ما لم يسم

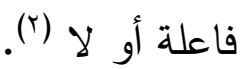

ب - الخلاف في جواز الجمع بين الألف واللام والإضافة أو لا (r). ع - الاختلاف في إعمال الأول أو إعمال الثاني في باب التنازع (؛). ه - الخلاف في وضع (منْ) مكان (منذ ) (०). 7 - الخلاف في حكايات غير الأسماء الأعلام (؟).

V - الخلاف في كون الجمل المحكية تثني وتجمع وترخم أو لا ؟(V). وغير ذلك من المسائل (^) أما ابن الفخار في كتابه (شرح الجمل ) فكان دائما يذكر مسائل الخلاف بين النحاة، بل ويذكر الرأي الراجح، ودليله، وذلك واضح في مواضع كثيرة من (شرح الجمل)، منها علي سبيل المثال:1 - الخلاف في كؤن الاسم مشتق من (س م و) كما هو مذهب البصرين، أو من (و س م) كما هو مذهب الكوفيين (9).

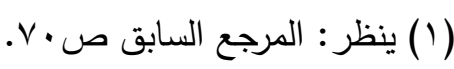

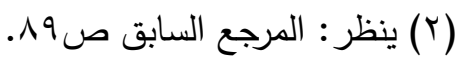

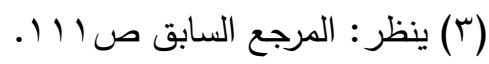

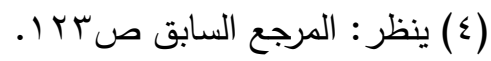

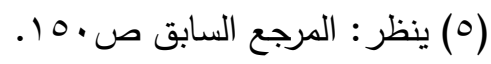

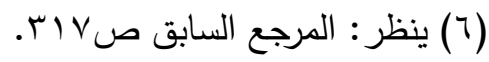

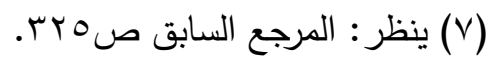

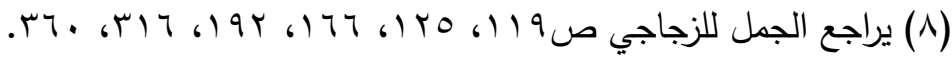

$$
\begin{aligned}
& \text { (9) ينظر : شرح الجمل لابن الفخار ص ع ع. }
\end{aligned}
$$


حوليت كليت اللغت العربيت بإيتاى البارود (العدد الثاني والثلاثون - المجلد الرابع)

r - الخلاف في كون الفعل مشتق من المصدر كما هو مذهب البصرينين أو

أن المصدر مشتق من الفعل كما هو مذهب الكوفيين (').

ب - الخـاف في كون (رب) للتقليل كما هو مذهب أكثر البصرين، أو أنها

للتكثير كما هو مذهب الكوفيين وبعض البصرين (r).

ع - الخلاف في كون (نعم وبئس) فعلان كما هو مذهب البصرين. وطائفة

من الكوفيين، أم هما اسمان كما هو مذهب بعض الكوفيين (r).

ه- الخلاف في إعمال الثاني كما هو مذهب البصرين، أو إعمال الأول كما

$$
\text { هو مذهب الكوفيين (ع). }
$$

7 - الخـلاف في كون المصـدر العامـل يرفع وينصـب عند البصـرين، أو

$$
\text { ينصب ولا يرفع عند الكوفيين (0). }
$$

V - الخلاف في منع جمع تمييز (كم) الاستفهامية عند البصريين، وجواز ذلك

عند الكوفيين (†)

هذه بعض المسائل التي دار فيها خلاف بين البصريين والكوفيين، وكان غالبا ما يرجح فيها ابن الفخار مذهب البصريين، وهناك مسائل أخري في (شرح الجمل)(V) فليرجع إليها مَنْ شاء. وإذا كان ابن الفخار يذكر مسـائل الخلاف بين البصرين والكوفيين إلا أنه في بعض الأحيان يقطع كلامه

$$
\begin{aligned}
& \text { (1) ينظر : المرجع السابق ص rr، سז. }
\end{aligned}
$$

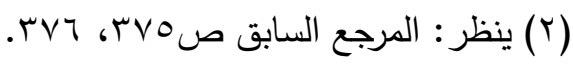

$$
\begin{aligned}
& \text { (r) ينظر : المرجع السابق ص } 919 .
\end{aligned}
$$

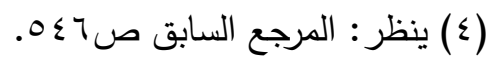

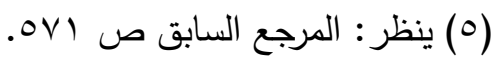

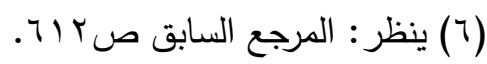

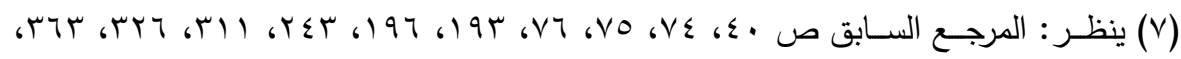
6 AYO 6VV 6V 
حوليت كليت اللغت العربيت بإيتاى البارود (العدد الثاني والثلاثون - المجلد الرابع)

(وفيه مع هذا نظر)(') أو يقول: (فإن في الموضع مجالا للبحث)(r). أو يقول: (فإن النظر فيه يفتقر إلي بحث)، () أو يقول: (علي ما هو مبسوط

في الأمهات)(ع)

** سابعا: من حيث التعليالات عند الزجاجي وابن الفخارة-

كان الزجاجي في كتاب (الجمل ) كثيراً ما يأتي بالتعليلات النحوية

عند ذكره لمسـئل الخلاف بين النحاة، فكان كل مـا يذكره من أحكام نحوية، وكل مـا يتجـه إلي تأييده من قواعد لـه علته التي تقتصسيه، وله سببه الذي يوجبه. فلكي تكون القواعد صحيحة مقبولة لابد أن تكون لها علل مقنعة، ومن أمثلة ذلك: -

(1) أنه ذكر عند الكلام في باب "ما لم يسم فاعله": (أنه إذا كان الفعل غير متعد إلي مفعول لم يجز رده إلي مـا لم يسم فاعله عند أكثر النحوين: لأنك إذا حذفت فاعله لم يبق ما يقوم مقامه وذلك قولك: خرج خحم وضحك بكر وقعد عمرو، ولا يجوز رده إلي ما لم يسم فاعله وقد أجازه بعضهم

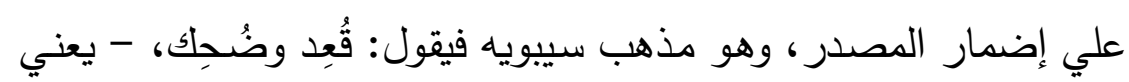

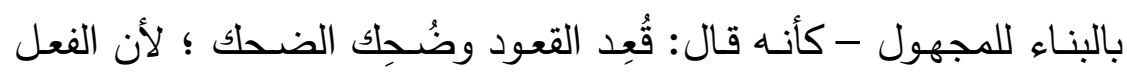
يدل علي مصدره وإذا كان الفعل يتعدي إلي المفعولين رفعت الأول منهما فأقته مقام الفاعل وتركت الآخر منصوبا علي حاله وذلك قوللك: أعطي زيد درهما، رفعت "زيـداً" لأنه مفعول مـا لم يسم فاعله، ونصبت الدرهم؛ لأنه مفعول ثان فبقي علي أصله، وإن شئت قلت: نصبته لأنه تعدي إليه فعل مفعول هو بمنزله الفاعل، وهو قول سيبويه، وتقرببه علي المتعلم أن

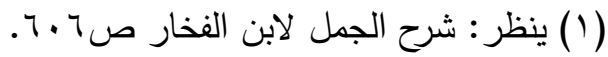
VAV VA (Y)

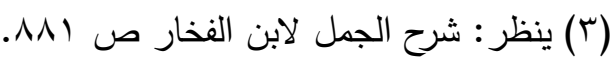
(ع) ينظر : المرجع السابق ص سوץ، میر. 


\section{دراسة موازنة بين منسجي الزجاجي وابن الفخار في تترح الجمل}

حوليت كليت اللغت العربيت بإيتاى البارود (العدد الثاني والثلاثون - المجلد الرابع) يقول: نصبته لأنه خبر ما لم يسم فاعله، وليس هذا من ألفاظ البصرينين،

$$
\text { ولكنه تقريب علي المبتدىء...)('). }
$$

(Y) وذكر في باب إضـافة المنادي إلي المتكلم ": ( أن للعرب في ذلك لغات

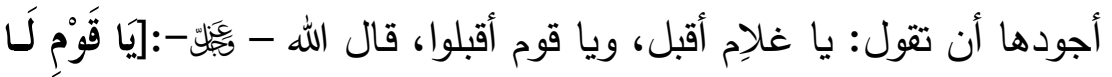

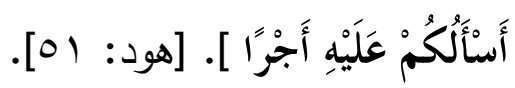

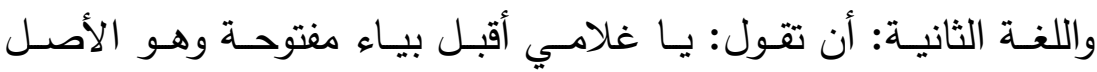
فتحركها: لأنها اسـم مضـر متطرف كما تحرك سـائر المضـمرات نحو التاء مسن قمـت، والكاف مسن غلامـك ومـا أشبه ذلك، واللغـة الثالثة: أن تقول: يـا غلامهي أقبـ فتسكن الياء استتقالا للحركة فيها؛ لانكسـار مـا قبلها، واللغـة الرابعة: أن تقول: يـا غلامـا تبدل الكسرة فتحة وتقلب الياء ألفا؛ لتحركها وانفتاح ما قبلها...)(r). (ب) وذكر في باب " تصغير الرباعي قوله: (اعلم أن تصغير ذلك كله علي مثال فعيعل وذللك قوللك في جعفر جعفير وفي سهلب سهليب، وفي أسود أسـيود لأنسه وإن كـان مـن الثلاثة فإنها يجري مجري الأربعـة، وإن شـأت قلت، أسيد فقلبت الواو ياء... وأمـا عجوز فيقول فيها عجيز ، ولا يجوز إظهار الواو : لأنها حرف مدولين)(r) وغير ذلك من التعليلات (ء) التي ذكرها الزجاجي في (الجمل)؛ لأنه حتي تكون القواعد مقبولة لابد لها من علل مقنعة.

(1) ينظر : الجمل للزجاجي ص 19 19، . 9.

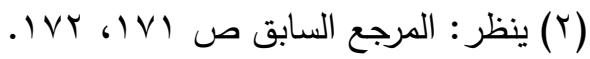

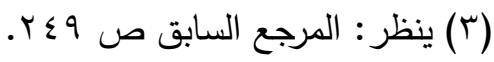

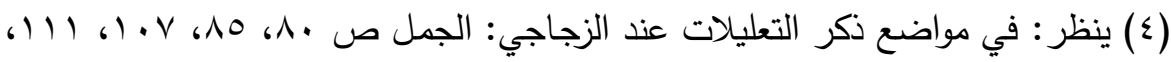

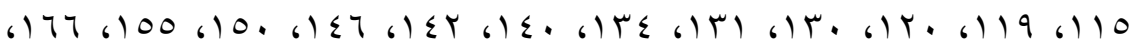

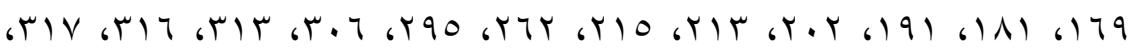




\section{دراسة موازنة بين منسجي الزجاجي وابن الفخار في تترح الجمل}

حوليت كليت اللغت العربيت بإيتاى البارود (العدد الثاني والثلاثون - المجلد الرابع) أما ابن الفخار فقد أتي بقدر أكبر من الزجاجي من التعليلات في كتابه (شرح الجمل) بل واهتم بها اهتماما كبيرا، فكل يذكره من أحكام وكل ما يتجه إلي تأييده من قواعد لله علته التي تقتضيه، وله سببه الذي يوجبه، بل ونجده يعول لما يؤيده بقوله: (ليجري الفرع علي الأصل)(') أو قوله:

$$
\text { (حمل ما ليس فيه سبب علي ما فيه سبب)(ب). بهاب) }
$$

أو قوله: (ليجري الكل علي أسلوب واحد)(r)، أو قوله: (والأصسل بقاء مـا

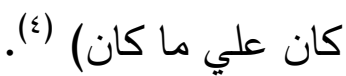

أو قوله: (اعتبار العدوم مقدم علي اعتبار الخصوص)(ْ).

أو قوله:(حمل الثيء علي جنسه أوْلي من حمله علي غير جنسه)(؟).

$$
\text { أو قوله: (حمل المطلق علي المقيد)(v). }
$$

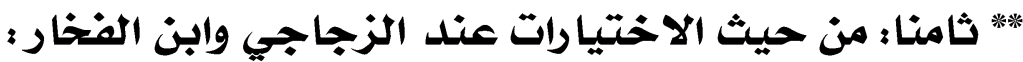

تعد الاختيارات النحوية التي اختارها الزجاجي في كتاب (الجمل) قليلة

جدا، فالمتتبع لجمل الزجاجي يري أنه كان قليلا ما يذكر اختيارات لله، ومن

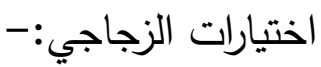

1 - اختياره كسر همزة "إن" بعد اليمين حيث قال: (وقد أجاز بعض النحوين فتحها بعد اليمين، واختاره بعضهم علي الكسر • والكسر أجود)(^).

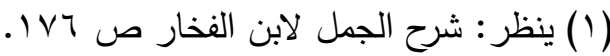

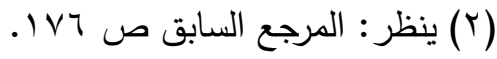

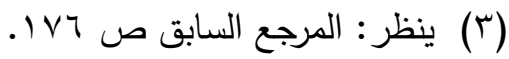

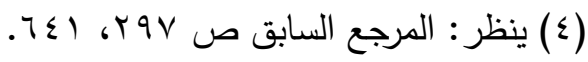
(0) ينظر : المرجع السابق ص (1) ل1)

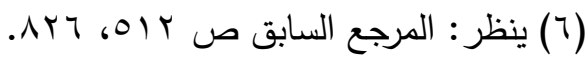
ينظر : المرجع السابق ص rT) (V) (^) ينظر : الجمل للزجاجي ص •. V. 


\section{دراسة موازنة بين منسجي الزجاجي وابن الفخار في تترح الجمل}

حوليت كليت اللغت العربيت بإيتاى البارود (العدد الثاني والثلاثون - المجلد الرابع)

r - اختياره النصـب في كل مقسـم بـه إذا حذفت منـه الحرف الجـار حيث

$$
\text { قال: }
$$

(وكل مقسم إذا حذفت منه الحرف الجار نصبته بإضمار فعل كقولك: الله لأخرجن، وربمـا جعلوا ألف الاستقهام عوضـا من الخـافض فخفضـا بها فقالوا: الله ليخرجن، ومنهم من يقول: عهد الله لأخرجن، ويمين الله وأمانه الله، ترفعه بالابتداء وتضمر الخبر ، كأنه قال عهد الله لازم لي. وأمانه الله لازمة لي بالرفع، والنصب أجود....)("). ب - اختياره في باب "الفاعلين المفعولين اللذين يفعل كل واحد منهما بصاحبة مثل يفعله الآخر إعمال الثاني" حيث قال: (أعلم أن الاختيار في هذا

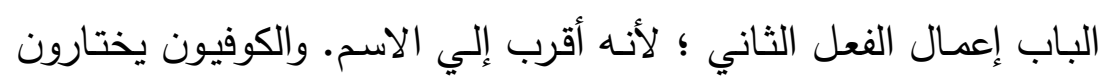
إعمال الأول: لأنه أسبق الفعلين وذلك قوللك: ضربت وضربني زيد علي

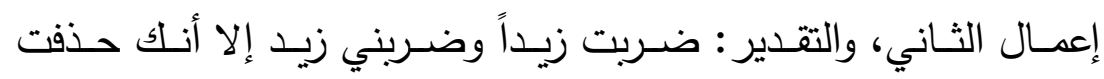
المفعول مـن الفعل الأول حذفا لاستغنائك عنهه وبدلالـة مـا بعده عليه، وفي التثثيـة ضـربت وضـربني الزيـدان وفي الجمسع ضـربت وضـربني

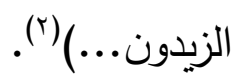

هذه بعض اختيـارات الزجـاجي في كتابـة (الجمل) وهنـاك اختيـارات أخري (r) له لَمْْ أراد الرجوع إليها. أمـا اختيارات ابن الفخار في (شرح الجمل) فهي كثيرة جدا، لاسيما وأن (شرح الجمل) من الشروح الطويلة، وكان ابن الفخار أطول نفسا فيه من غيره الذين شرحوا (الجمل) ومن ثم سأختار بعض تلك الاختيارات، ومنها:| إعراب الأسهاء الستنم:-

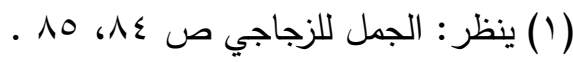

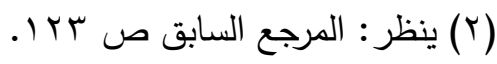

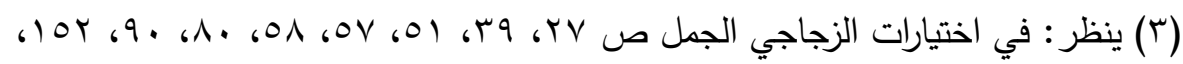

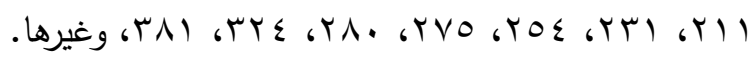


حوليت كليت اللغت العربيت بإيتاى البارود (العدد الثاني والثلاثون - المجلد الرابع) ذكر ابن الفخار في إعراب الأسماء الستة سبعة مذاهب هي:-

أ - أنها معربة بحركات علي أواخرها مقدرة واتبع ما قبل الآخر الآخر. ب - أنها معربة بالحروف.

ج - أنها معربة بالحركات التي قبل هذه الحروف، والحروف إثباع. د - أنها معربة بشيئين بالحركات والحروف معا.

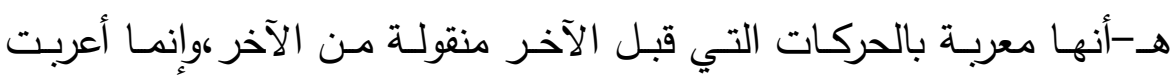
بالحركات؛ لأنه الأصل

و - أنها معربة بالتغير والانقلاب ؛ لأنها صفة محلها لام الكلمة، فصار ذلك الك بمنزلة الحركة في الدال من زيد مثلا. ز - أن هذه الأسماء علي قسمين قسم يعرب بالحروف وهي: أخوك، أبوك، حموك، هنوك وقسـ يعرب بالحركات مقدرة في الحروف وهو : فوك، ذو ؛ لأنهمـا لـو أعربـا بالحروف كالقسم الأول للزم بقاؤهـا علي حرف وليس ذللك في القسم الأول. قال ابن الفخار : والصحيح من هذه الأقوال الأول(') وهو ظـاهر مـذهب سـيبويه(r)، ونس أبي علي في النصف الثاني من الإيضاح)(r) والسبب في صحة هذا القول (أن أصل جاء أَخَوُك أخَوك بفتح الخاء

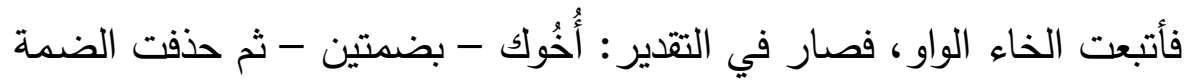
من الواو تخفيفا فصسار : أخوك كمـا تري، وفي النصسب: رأيت أخالك وأصله أَخَوَكَ - بفتحات - فانقلبت الواو ألفا ؛ لتحركها وانفتاح ما قبلها، وفي الخفض مررت بأخيك وأصله: مررت بأخَوِك فاتبعت الخاء الواو فصار : بأخوك، ثم

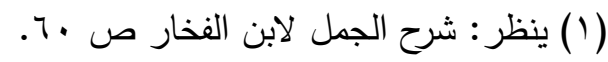

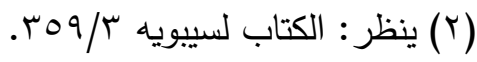

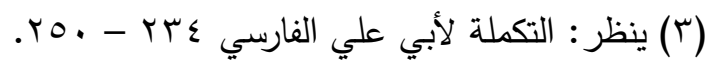




\section{دراسة موازنة بين منسجه الزجاجي وابن الفخار في تترح الجمل}

حوليت كليت اللغت العربيت بإيتاى البارود (العدد الثاني والثلاثون - المجلد الرابع) حذفت كسرة الواو تخفيفـا فصسار في التقدير : بأخوك بـواو سـاكنة بعد كسرة

فانقلبت لذلك ياء فصار بأخيك)(').

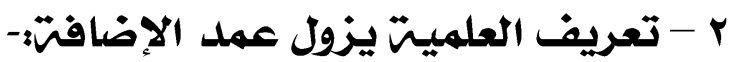

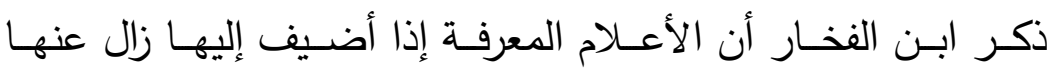

التعريف؛ لأنه لو لم يزل لأدي إلي الجمع بين تعريغين إن كان المضاف إليه معرفة، أو إلي الجمع بين تعريف وتتكير علي اسم واحد وكلاهما ممتتع فقال: (ومما يلزم زواله عند الإضافة تعريف العملية لما يلزم علي بقائه من

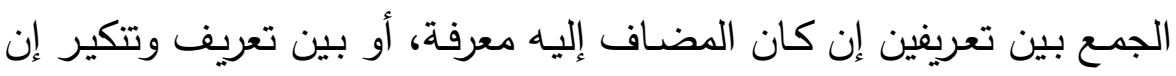
كان نكرة) (r)

وما قاله ابن الفخار خالف فيه ابن الطراوة الذي ذكر أن هذا التعريف

الذي في العلم لا يزول وإنما الإضافة ؛ لرفع الاشتراك العارض في الأعلام.

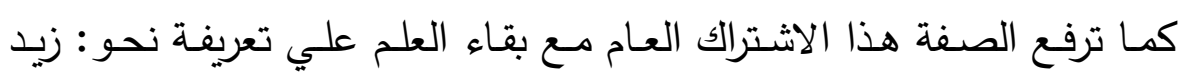
الطويل.

قال ابن الفخار : (ولا بأس بهذا القول لو لا ما ثبت من أن المضـاف يكسب

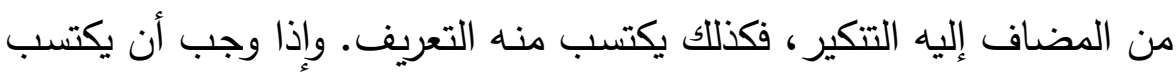
منه التعريف وجب زوال تعريفة السـابق، لما يلزم علي بقائهه من الجمـع بين تعريفين فهذا هو الصحيح إن شاء الله) (־).

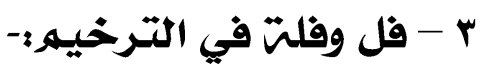

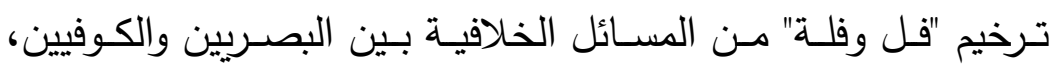
فالكوفيون يرون أن "فل" ترخيم فلان، "وفلة" ترخيم فلانة.

$$
\begin{aligned}
& \text { (1) ينظر : شرح الجمل لابن الفخار صلو. }
\end{aligned}
$$

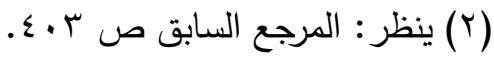

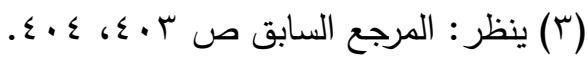




\section{دراسة موازنة بين منسجي الزجاجهي وابن الفخار في تترح الجمل}

حوليت كليت اللغت العربيت بإيتاى البارود (العدد الثاني والثلاثون - المجلد الرابع) أما البصريون فيرون أن "فل وفلة" مدا خص بـه النداء وأن ما حذف منه علي غير قياس وليس بترخيم فلان وفلانه وإنما هما كيد ودم ونحو ذلك مما حذف منه وبقي الاسم بعد الحذف بمنزلته لو وضع كذلك. واختار ابن الفخار مذهب البصرين قائلاً: (ولو كان يـا فل ترخيم فلان لم يحذف منه إلا النون وحدها؛ لأنه لا يجوز بقاء الاسم في النداء علي حرفين إلا ما كان في آخره تاء التأنيث فكنت تقول: يا فلا بالألف ويدل علي ذلك قولهم في المؤنثة يـا فلة أقبلي ولو كان ترخيم فلانـة لم يحذف منه إلا التاء وحدها؛ لأن ما آخره تاء التأنيث لم يحذف منهه غيرها، قلت حروفه أو كثرت، فدل ذلك علي صحة قول البصرين من أنه حذف علي غير قياس لا علي وجه الترخين. و الله أعلم)(').

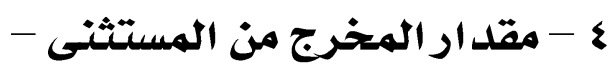

المستثنى عند ابن الفخار يتلخص في ثلاثة مذاهب:-

أحدهما: أن يكون المستثنى أقل من نصف المستثنى منهه نحو لله عشرة إلا ثلاثة.

الثاني: ألا يكون المستثنى أكثر من نصف المستثنى منه أي: أن يكون نصفا فما دون.

الثالث: عدم اشتراط أن يكون المستثنى أكثر من نصف المستثنى منه أو أقل وهذا هو المذهب الصحيح عند ابن الفخار حيث اختاره قائلا: (إطلاق القول بالقدر المخرج هو الصحيح خلافا لمن اشترط نقصانه عن الباقي، ولمن اشترط عدم زيارته عليه)(r). - هله لهك ولأخيك:-

هذه المسالة سؤل عنها أبو بكر بن زيد وهي: "هلم لك ولأخيلك" فقال: لا تجوز لأن "لك" تفسير للمضدر في "هلم"، والمعطوف علي التفسير تفسير

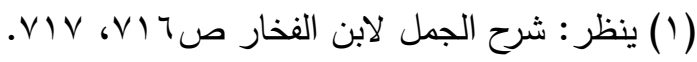

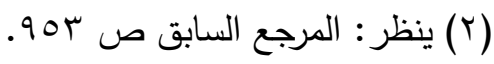


حوليت كليت اللغت العربيت بإيتاى البارود (العدد الثاني والثلاثون - المجلد الرابع)

فلزم أن يكون المفسر بهما ضميري مخاطب وغائب، واسم الفعل لا يتحمل ضـمير غائب أصسلا. قـال ابـن الفخـار : (والذي أقوله في هذه المسألة أنها جائزة، وليس في هلم ضمير غائب أصسلا، وإنما فيها ضمير مخاطبين علي سبيل التغليب، وهي في ذلك بمنزلة ما هي اسم لله فكما يجوز بإجماع أقبلا تعني مخاطبا وغائبا، إلا أنه وقع التغليب في المستتر ، ولم يقع في التفسير؛ لأنه منقطع مما قبله، ولو فعل لجاز ، فكان يقال، هلم لكما فتفهم ذلك، وبالله

(التوفيق) (1)

واختيارات ابن الفخار كثيرة جدا في (شرح الجمل) لمن أراد الاطلاع

عليها، وأذكر فقط أسماء المسائل التي كان له اختيار فيها وهي:-

I - العطف علي الضمير المخفوض(؟).

r - إبدال الظاهر من ضمير المتكلم والخاطب(r).

r - تقديم المصدر المؤكد(ع).

؟ - العطف علي موضع "إن" (0).

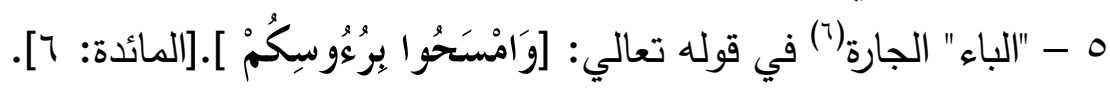

7 - زمن فعل التعجب(v).

- V مذ ومنذ

(1) ينظر : شرح الجمل لابن الفخار ص Vף • . .

(Y) ينظر : المرجع السابق صـ IV - IV

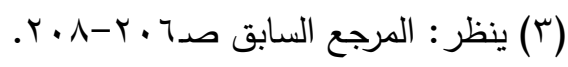

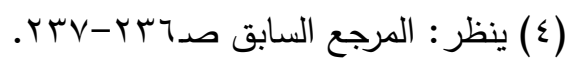

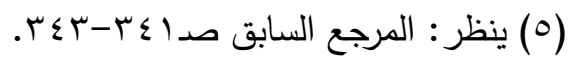

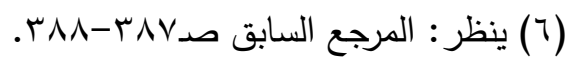

(V)

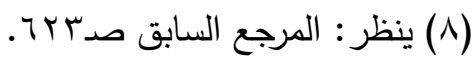


حوليت كليت اللغت العربيت بإيتاى البارود (العدد الثاني والثلاثون - المجلد الرابع)

^- معني العدل في "آخر" (1).

9- صرف المؤنث الثلاثي الساكن الوسط غير الأعجمي (r).

• 1 - تسمية المؤنث باسم مذكر (r).

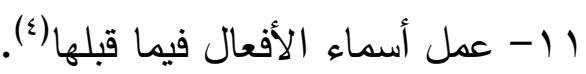

r ا - تصغير "مجلبب" (0).

ب ا - النسب إلي "عدوة" (†)

** تاسعاً: - من حيث المخالمات لبعض النحاة عندل الزجـاجي وابن

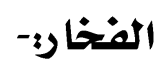

كان الزجـاجي في كتابـه (الجمـل) قليلا مـا يـذكر مخالفـات نحويـة

لبعض النحاة، ومن أمثلة ذلك مخالفته للكسائي في باب: "الفاعلين المفعولين اللذين يفعل كل واحد منهما بصاحبه مثل ما يفعله الآخر" وقد اختار الزجاجي إعمال الفعل الثاني ؛ لأنه أقرب إلي الاسم كما هو مذهب البصرين. واختار الكوفيـون إعمـال الأول؛ لأنـه أسـبق الفعلـين نحـو : ضـربت وضـربني زيـداً والتقدير : ضربت زيداً وضربني، ففي قولك: ضربني ضديران أحدهما ضمير المفعول وهو النون والياء، والآخر في النية وهو ضمير الفاعل يرجع إلي زيد، وتقول في التثنيـة ضـربت وضـرباني الزيـدين؛ لأن التقدير : ضـربت الزيـين وضـرباني فظهرت علامـة المضـدر الفاعـل في التثنيـة، وتقول في الجمـع: ضربت وضربوني الزيدين علي ذلك التقدير •

$$
\begin{aligned}
& \text { (1) ينظر : المرجع السابق صـ ب991. }
\end{aligned}
$$

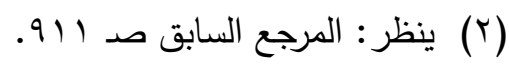

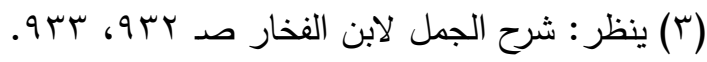

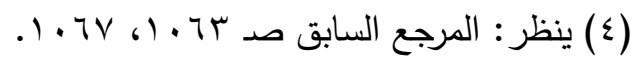

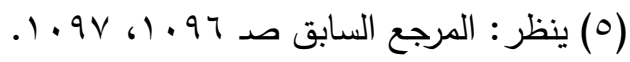

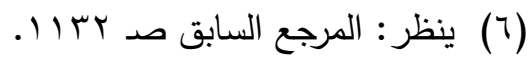


حوليت كليت اللغت العربيت بإيتاى البارود (العدد الثاني والثلاثون - المجلد الرابع) وتقول: ضربني وضربت زيداً علي إعمال الثاني فتضمر في: ضربني

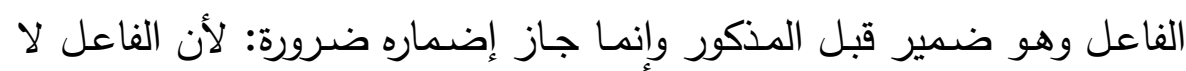
يستغني عنه، والمفعول قد يستغني عنه، فلذلك لم تضدره في المسألة الأولي، وتقول في التثنية ضرباني وضربت الزيدين، ثنيت الضمير الذي في النية كما ذكرت للك، وتقول في الجمع: ضربوني وضربت الزيدين.

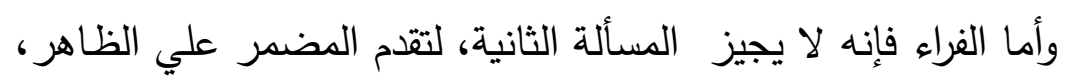
والكسائي يجيزها علي حذف الفاعل ولا يثني ولا يجمع ؛ لأنه لا مضدر عنده في الفعل.

وخالف الزجاجي الكسائي في ذلك قائلاً: (وهذا غلط؛ لأن الفعل لا

يخلو من الفاعل ضرورة)(').

أما ا بن الفخار فقد ذكر الكثير من المخالفات النحوية لعدد كبير من النحاة، وأذكر علي سبيل المثال بعض هذه المخالفات ومنها:أ- هخالمن ابن الفخار رلسيبويه؛-

ذكـر ابـن الفخـار أن ( مـن الابتـائيـة لا تـدخل علي الزمـان عند

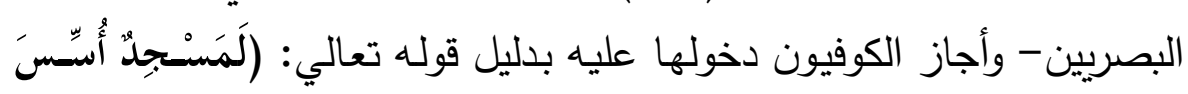

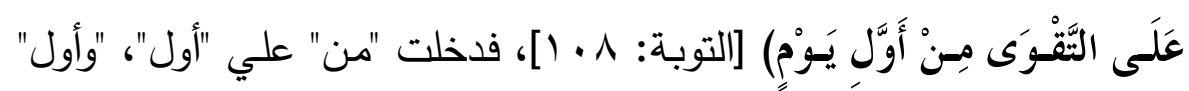
هنا يدل علي الزمان، ورد البصريون هذا الجواب بما هو مبسوط في (شرح

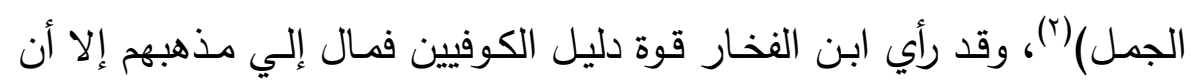
سيبويه كان علي خلافه لذلك قال: (ولولا أن ظاهر كلام سيبويه ما قاله أبو القاسـم لقلنـا في المسـألة بقـول الكـوفيين؛ لأنـهـ تـأتي مواضــع يعسـر فيهـا

$$
\begin{aligned}
& \text { (1) ينظر : الجمل للزجاجي صد سץ| - 0ب ا. }
\end{aligned}
$$

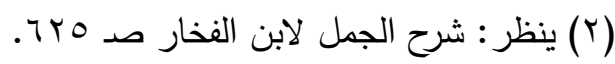


حوليت كليت اللغت العربيت بإيتاى البارود (العدد الثاني والثلاثون - المجلد الرابع)

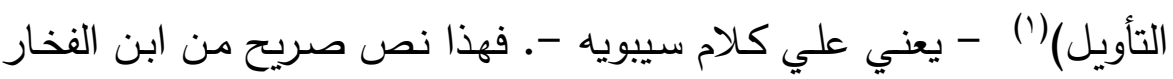

من مخالفته لسيبوية(r).

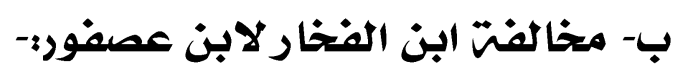

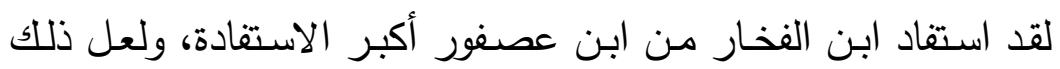
يرجـع لتواردهمـا علي كتاب مشـروح واحد هو (الجمل)، ومـع استفادة ابـن الفخار من ابن عصفور إلا أنـه رد عليه بعض المسـائل، وجاءت ردود ابن

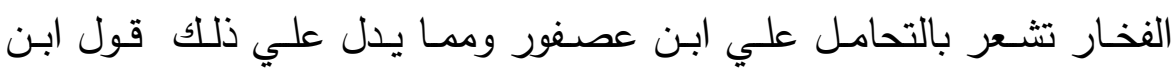
الفخار : (وليس علي الوجه الذي قاله ابن عصفور ، فلم يصنع في هذه المسألة

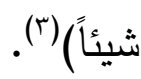

وكانت ردود ابن الفخار علي ابن عصفور في غالبها قصيرة، سهلة

الإدراك، ولم تصطبخ بما اصطبغت به الردود الأخرى من إطالة(؛).

ومن نماذج مخالفت ابن الفخار لابن عصفور: مسأنت رافع الخبر.

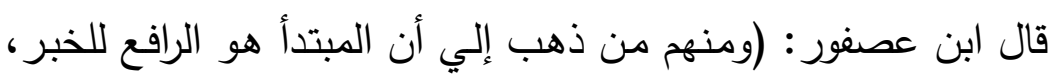

وذلك باطل بدليلين:-

أحدهما:- أن المبتدأ قد يرفع فاعلاً نحو قوللك: "القائم أبوه ضاحك"، باكل

ولو كان رافعا للخبر لأدي ذلك إلي إعمال عامل واحد في معمولين رفعا من

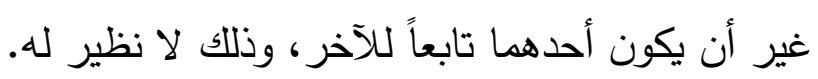

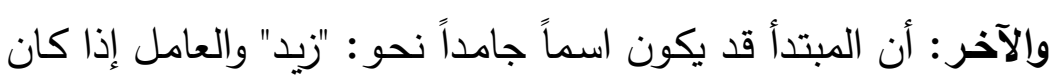

غير متصرف لم يجز تقديم معدوله عليه، والمبتدأ يجوز تقديم الخبر عليه، فذل ذلك علي أنه غير عامل فيه)(•).

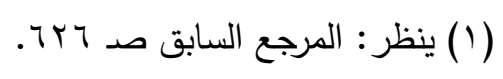

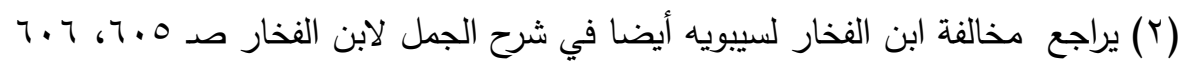

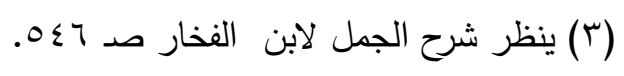

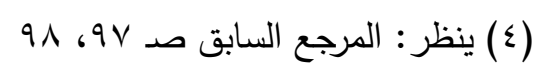

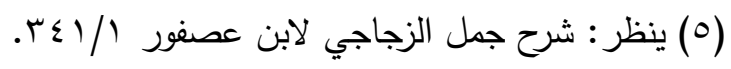


حوليت كليت اللغت العربيت بإيتاى البارود (العدد الثاني والثلاثون - المجلد الرابع)

وقل رد ابن الفخار مذهب ابن عصفور هذا قاثلاً:-

(وهذا نظر ضعيف، أما قوللك: "القائم أبوه ذاهب" فإن القائم لم يرفع

الفاعل من حيث هو مبتدأ بل من حيث هو اسم فاعل بمنزلة الفعل، وأما رفعه

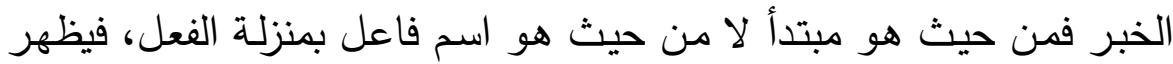

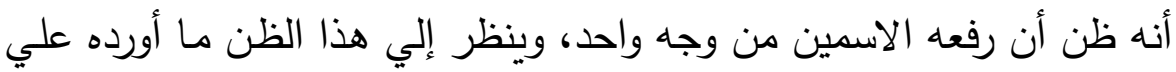

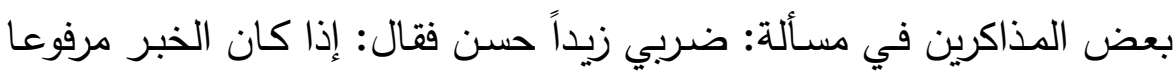
بالمبتدأ الذي هو: ضربي فهو من صلته، والصلة والموصول لا يستقل منها كلام فأجبته بنحو مـا تقدم، وهو أن رفعه للخبر من حيث هوبث هو مبتدأ لا من هن حيث هو مصدر ، وعمله في صلته من حيث هو مصدر لا من حيث هو

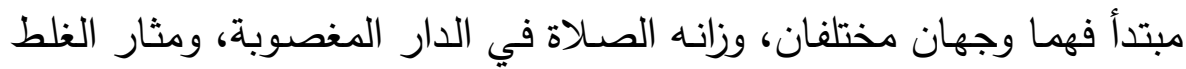
عدم التحقيق. وأما الجواب عن الثاني: فإن عمل المبتدأ في خبره ليس محمولاً علي غيره ولا مشبها به، وإنما عمل فيه بشرط الأولية الوضعية، وعدم العوامل اللفظية، وهذا المعني فيه موجود وإن تقدم خبره عليه، وإنما يمتنع العامل من العمل في معموله مقدماً عليه، إذا كان محمولاً علي غيره في العمل، ومشبها وهيها

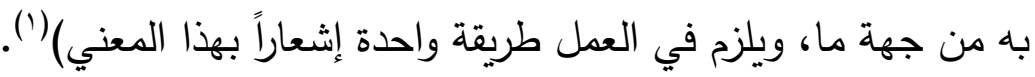
هذا نموذج من رد ابن الفخار علي بن عصفور ، وهناك ردود أخري

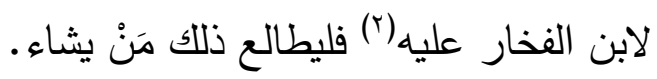

\section{ج- مخالفت ابن الفخار لأبي الحسين بن أبي الربيع:-}

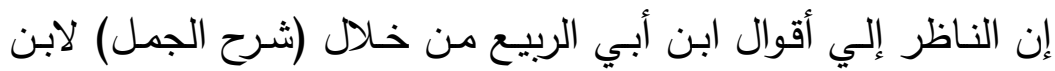
الفخار يجد أنها تحظي بكل احترام مع كثرتها، وكان ابن الفخار ما يصف

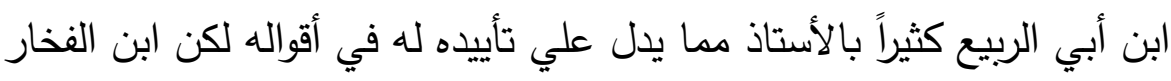

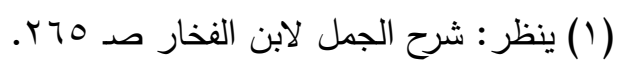

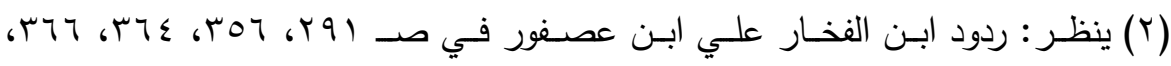
(1) الجمل لابن الفخار. 


\section{دراسة موازنة بين منسجه الزجاجي وابن الفخار في تترح الجمل}

حوليت كليت اللغت العربيت بإيتاى البارود (العدد الثاني والثلاثون - المجلد الرابع) خالف ابن أبي الربيع في مسائل قليلة جداً منها:-- مسألة "النسب إلي اثنين وإلي اثني عشر مسمي بهما" والمسألة هي:-

ذكر ابن أبي الربيع أنسه لـ فرض أن هناك رجلين أحدهما اسـهـ:

"اثنان "، والآخر اسمه "اثنا عشر" لم ينسب إليهما؛ لوجود اللبس، وذلك أن الاسم إذا كان مركباً ونسب إليه حذف عجزه ونسب إلي صدره، فإذا حذفت من: "اثني عثر " العجز اتفق مـع "اثنين" في اللفظ، ففي النسـب إلي هذه الصورة لبس، هذه حجة ابن أبي الربيع. أما ابن الفخار فقل رد ذلكي، وأجازما منعه ابن أبي الربيع قاثلاً:(وعندي أنه يجوز النسب إليه، ولا يراعي اللبس في الأعلام، ألا تري أن النسـب إلـي المثني والمجموع جمـع سـلامة أو جمـع تكسير بـالرجوع إلـي الواحد كائناً من كان، وذلك كله يشبه النسب إلي الواحد، وكذلك إذا سميت بزيدين، أو بالزيدين، وحكيت إعرابهما نسبت إليهما كالنسب إلي الواحد، ولا

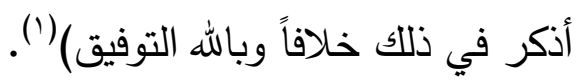
د- مخالمنت ابن المنخار لأبي حيان:خالف ابن الفخار أبـا حيان في مسألة : "تقديم التمييز علي عامله الفعل".

إذ يري أبو حيان أنه يجوز قياساً وسماعاً تقديم التمييز علي عامله

الفعل، وقد ذكر أبو حيان أنه أخرج مبيضة علي ابن مالك قرأ عليه فيها وجه القياس، وأنشد من السماع أبياتاً كثيرة(r)، وما كان من ابن الفخار إلا أنه رد أنه مذهب أبي حيان قائلاً:-

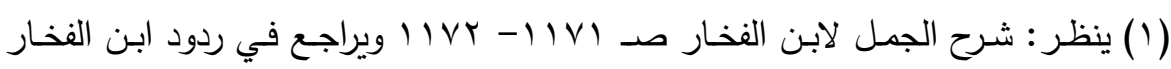

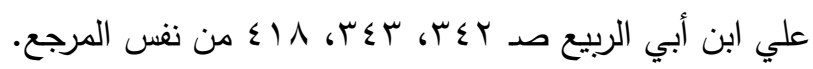

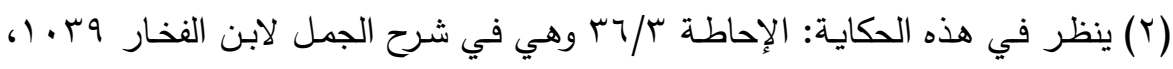




\section{دراسة موازنة بين منسجي الزجاجهي وابن الفخار في تترح الجمل}

حوليت كليت اللغت العربيت بإيتاى البارود (العدد الثاني والثلاثون - المجلد الرابع) (يرحم الله الشيخ أبا حيان، لقد أغفل أصسلًا عظيماً من أصسول النحو مع كثرة دوره علي ألسنة المعربين، وذلك أن تقديم التمييز علي عامله إذا كان فعـلً لو كان جائزاً عند العرب كالحال لكثر نظماً ونثراً كثرة لا يمكن فيها

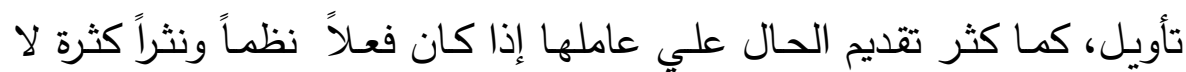
يمكن فيها تأويـل فلمـا كان الأمـر علي خـلاف ذلك دل دلالكة واضحة علي امتتاع العرب من تقديمه علي عامله وإن كان فعلاً، واختصاص ذلك بالثعر مع كثرة استعماله دليل علي أنه من ضرائره وبالله التوفيق)( '). ثم أورد ابن الفخار كلام ابن مالك وأتباعه في هذه المسألة، وبسط المسألة بسطاً لا يتحمله المقام هنا(r). *** وقد خالف ابن الفخار غير هؤلاء من الأئمة النحوين الذين سبقت الإشارة إليهم، ومما يجب التتبيه عليه أن مخالفته لهؤلاء الأئمسة لا تعني عدم احترامه لهم، بـل كان ابـن الفخـار يحترم آراءهم، ويعرف لهم قدرهم ومنزلتهم، وفي (شرح الجمل) ما يشير صراحة إلي تلك المخالفات، وأكتفي هنا بذكر أسماء هؤلاء الأئمة الذين خالفهم ابن الفخار دون ذكر للمخالفات نفسها ؛ لأن المقام لا يتحملها بل أشير إلي صفحاتها في (شرح الجمل).

\section{وهؤلاء حسب وفياتهير:}

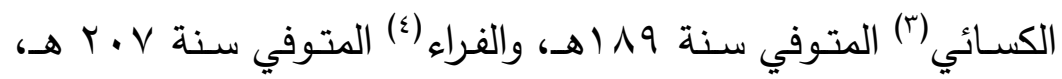

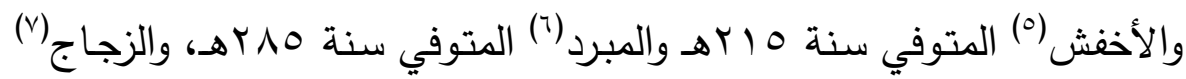

$$
\begin{aligned}
& \text { (1) ينظر : شرح الجمل لابن الفخار صد • ع. ـ وما بعدها. } \\
& \text { (r) ينظر : المرجع السابق • • • (ا، وما بعدها. }
\end{aligned}
$$

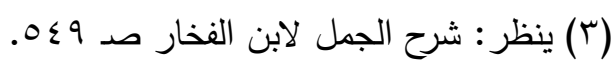

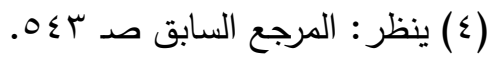

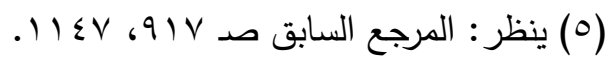

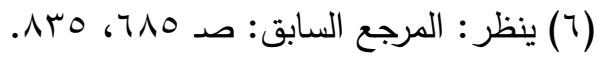

$$
\begin{aligned}
& \text { (V) }
\end{aligned}
$$


حوليت كليت اللغت العربيت بإيتاى البارود (العدد الثاني والثلاثون - المجلد الرابع)

المتوفي سنة ا(ساه، وابن السراج(') المتوفي سنة ج اسهـ والسيرافي (ז) المتوفي

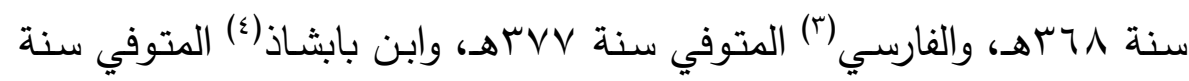

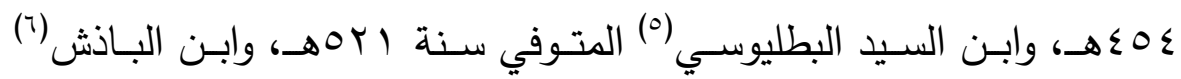

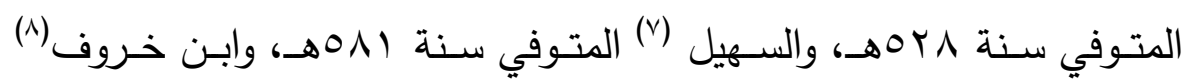
المتوفي سنة 9 • 7، وأبو علي الشلوبين (9) المتوفي سنة 0 أ جه وابن الحاجب

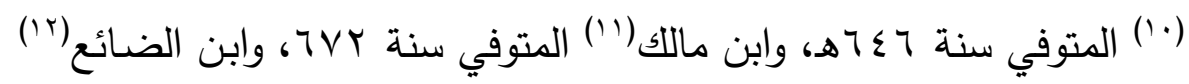

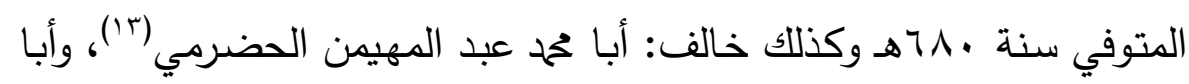

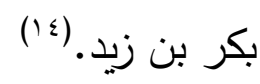

\section{"عاشرا:- من حيث أسلوب الزجاجي وابن الفخار:}

إن أسـلوب الزجـاجي في كتـاب (الجمـل) ســل, ميسـر , بعيد عـن

التعقيد, واضح العبارة, قريب المتناول لكل مَنْ يقرأ فيه, بل ويعد (الجمل) في

$$
\begin{aligned}
& \text { (1) ينظر : المرجع السابق صـ بوجr (1) }
\end{aligned}
$$

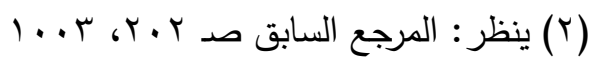

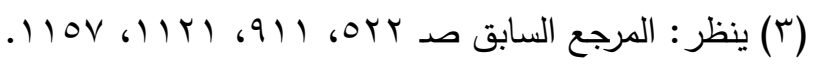

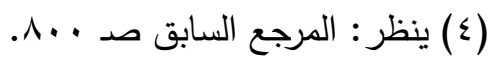

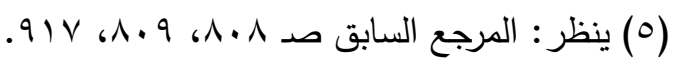

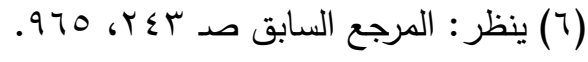

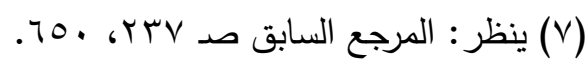

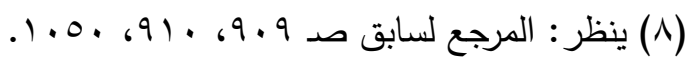

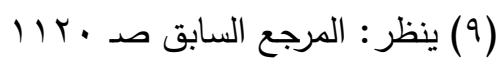

$$
\begin{aligned}
& \text { ( • (1) ينظر : المرجع السابق صـ } 970 .
\end{aligned}
$$

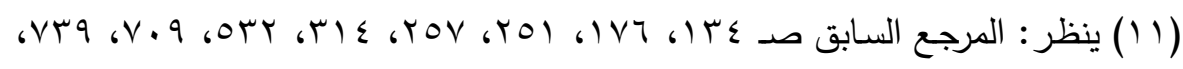

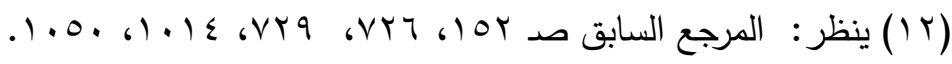

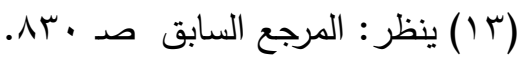

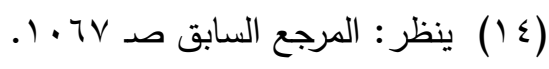


حوليت كليت اللغت العربيت بإيتاى البارود (العدد الثاني والثلاثون - المجلد الرابع) أسـلوبه مـن أفضـل الكتب وضـوحا وبيانـا, لأنسه قريـب إلـي الفهم, وقد صـرح الزجاجي بذلك قائلا:

(وليس هذ ا من ألفاظ البصرين, لكنه تقريب علي المبتدى)('). وأسلوبه أدبي عذب ,يعني بتقريب النحو إلي أفهام الناس عامه, وأفهام المبتدئين خاصـه؛ لأنه خال من جفاف الحدود, بـل يصل إلي تقرير وقواعد النحو بسـهوله, مـع براعة في تحليل القواعد, والتعليل لها مدا يثد القارئ إلي متابعة القراءة دون ضجر أو نفور • أمسا أسـلوب ابـن الفخـار في (شـرح الجمـل) فيبدو صـعبا, وعباراتهـ غامضـة غير سلسـة, وتكاد عباراته ومسـائله تستغلق علي الفهـ, ولعل ذلك يرجع لأنه كان يورد المسائل ثم يعود إليها مرات أخري فيبسطها تحت عناوين كثيرة فتراه مره يقول: (عبارة أخري)(r). ومـره يقول: (إمـلاء آخر) (ّ)، ومـره يقول: (عبـارة أخري أبسط مدـا

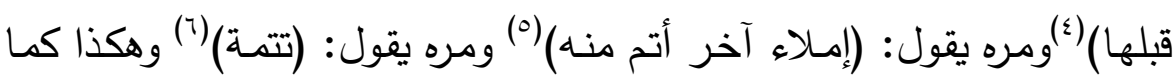
سبق في الحديث عند عرض المادة العلمية. ومن ثم فإن (شرح الجمل) لابن الفخار يحتاج إلي مراجعه (الجمل) نفسه؛ حتي تتضح الفكرة المراد شرحها.

$$
\begin{aligned}
& \text { (1) ينظر : الجمل للزجاجي صد.9.9 (1) : (1) }
\end{aligned}
$$

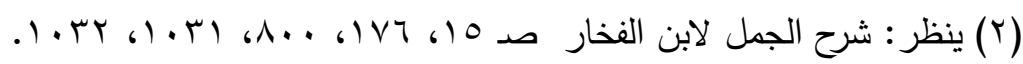

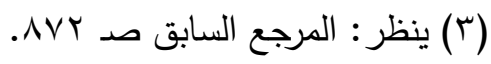

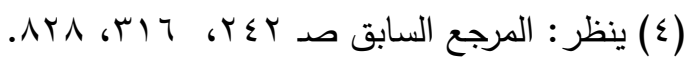

$$
\begin{aligned}
& \text { (0) ينظر : المرجع السابق صـ } 7 \text {. . } 9 .
\end{aligned}
$$

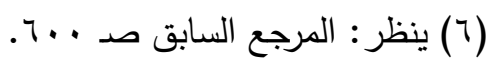




\section{دراسة موازنة بين منسجه الزجاجي وابن الفخار في تترح الجمل}

حوليت كليت اللغت العربيت بإيتاى البارود (العدد الثاني والثلاثون - المجلد الرابع)

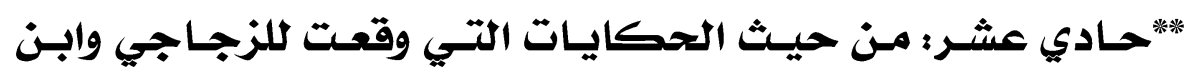

الفنخار وحضرها كل منهما:-

إن المتصفـح لكتاب (الجمل) للزجـاجي يجد أنـه لـم يـكر شـيئا عن فـ

الحكايات التي وقعت له أو حضرها أو سمعها في المجالس العلمية , وإما أن يرجع ذلك لكون ذلك لم يحدث له أصسلا, أو حدث لـه لكنه لم يشر لـه في كتابه؛ لأن الكتاب متن وليس شرحا, وليس المقام فيه مقام ذكر للحكايات التي

وقعت أو سمعها في المجالس العلمية.

بخلاف ابن الفخار في (شرح الجمل) فقد ذكر الحكايات التي وقعت

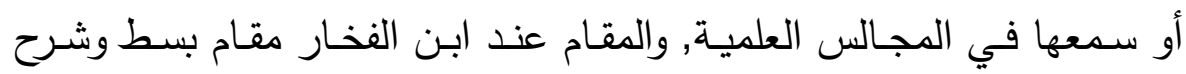

وتفصيل, ومن ثم ذكر تلك الحكايات ومنه علي سبيل المثال:-

1 - خبر ذكره عن أحد طلبة قصر عبد الكريم حين دخل عليهم بمسجد القفال بسبته, وأن ذلك الطالب يروي أن كلمة (مهلة) التي تقال في (ثم) أنها

للترتيب, و "المهلة لا تكون إلا بفتح الميح"(1).

r- سؤال من المرية (r)عن حكم (أم) العاطفة, و (أم) المنفصلة(r).

ب- سؤال آخر ورد عليه من المرية(أ) أيضا عن (أما).(0)

ع - سؤال أورده بعض المذاكرين عن مسألة: (ضربي زيد أحسن)(ج).

(1) ينظر : شرح الجمل لابن الفخار صـ باج I. (Y) (Y) المريـة بفتح الميم - وكسر الراء المهملة، وتثديد الياء المثناة من تحتها وبعدها هاء هـي: مدينـة كبيرة بالأندلس علي شـاطئ البحر، مـن مراسـي المراكب ينظر معجم

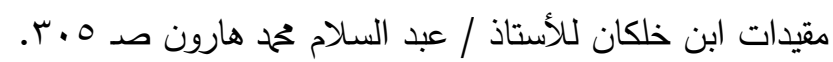

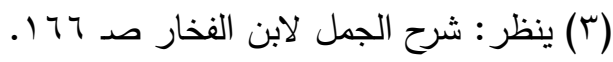

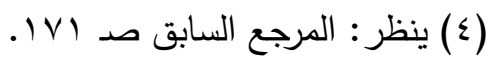

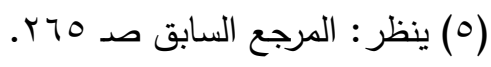
(ך) ينظر : المرجع السابق صـ اسب. 
حوليت كليت اللغت العربيت بإيتاى البارود (العدد الثاني والثلاثون - المجلد الرابع)

0- فوائد ذكرها حدثت بين المذاكرين حين قراءة باب: الحروف التي تتصب

$$
\text { الاسم وترفح الخبر • }
$$

ج- مسـألة نحويـة في بـاب:" النعـت " ذكر أنهـا كانـت سـبب عمـي الأعلـم

الشنتمري (1)

- V

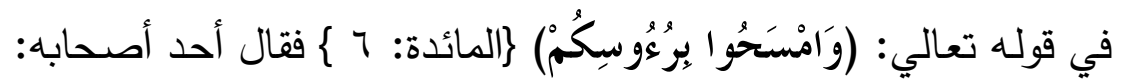

إنها للإلصاق ثم شئل هو فأجاب بما يخالف صاحبه (r).

1- خبر في رؤيا رآها أحد الفقهاء (r).

9-خبر في مسألة سألها الشيخ أبو زكريا الدكالي عن فائة قوله تعالي: رتلْكَكَ

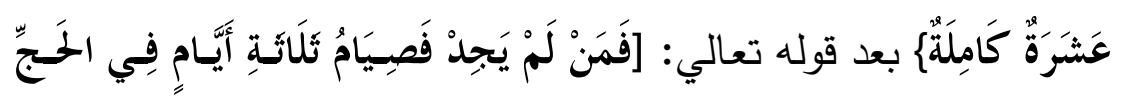

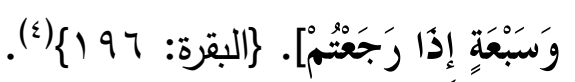

• ا-حكاية حدثت لـه في مجلس الإمام أبي الحسن الصـغير بمدينة فاس حرسها الله - وهو يتكلم في الأقراء في قول تعالي: [وَالمُطَلَّقَاتُ يَتَبَّصْْنَ

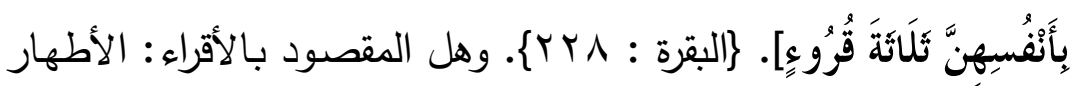

$$
\text { أو الحيض(0). }
$$

1 ا-خبر في مسألة حضرها بين أبي حمد عبد المهيمن الحضرمي , وأبي عبد الله بن عبد المنعم (؟).

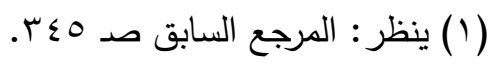

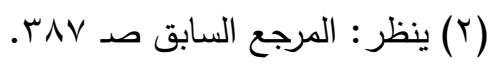

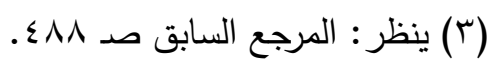

(ع) ينظر : شرح الجمل لابن الفخار صـ ONV.

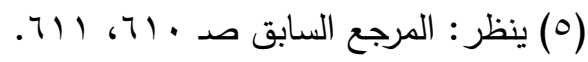

(T) ينظر : المرجع السابق صد • VI. 
حوليت كليت اللغت العربيت بإيتاى البارود (العدد الثاني والثلاثون - المجلد الرابع) r ا-خبر في مسـألة حدث عنها: أن محفـلاً عظيما جمع أعيان أهل سبته, وسأل ابـن الفخـار عن مسـألة فلم يجبـه علي سؤاله إلا أبو حمد عبد

\section{المهيمن الحضرمي (')}

ب ا - مسـألة سـأل فيها أبو اسـحاق بن أبي العـاص، وكان ابن أبي العاص معجبا بالغرائب، لكنه كان ضنيناً بهاب(r). ء ا-مسألة رواها الثيخ ابن حفيد الأمين عن شيخ بالقاهرة أوقف طالبا يجود القرآن عليه ؛ ليفيد بفائدة ثم لم يفعل(r). ه ا-خبر دخول أحد المشـارقة ويسـي: ابن واش علي أبي إسـاق الغـافقي وسؤاله عن مسألة تعرض الجواب عليها أحد الطلبة، ولم يرتض ابن

$$
\text { واش جوابه(£). }
$$

هذه الحكايات والأسئلة التي أوردها ابن الفخار في (شرح الجمل)، ومثل هذه الحكايات لها طرافتها في الدرس النحوي.

\section{* ثاخي عشر:- من حيث الشواهل عند الزجاجي وابن المخخار:-} لقد استثـه الزجاجي في كتاب (الجمل) بأصسول الاستثـهاد الثلاثة

وهي:- القرآن الكريم، والحديث النبوي الشريف، وكلام العرب شعراً ونثراً. وكذلك ابـن الفخـار (في شـرح الجمـل) فقـد استشـهد بتلك الأصـول الثلاثة، لكن هناكك بعض الاختلاف في عدد ما استشهد به كل منهما من تلك الأصول، واليك توضيح ذلك:-أ- القرآن الكربه وقراءاته:استشـهد الزجـاجي في كتابـه (الجمـل) بالآيـات القرآنيـة الكريمـة علي إثبات القواعد النحوية، وتقعيد قواعد النحو وتتبيتها، حيث لا خلاف بين النحاة

$$
\begin{aligned}
& \text { (1) ينظر : المرجع السابق صـ • •rم. }
\end{aligned}
$$

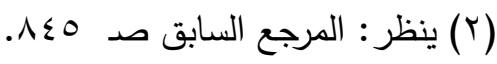

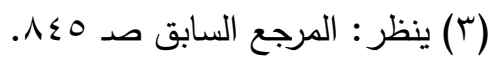

$$
\begin{aligned}
& \text { (ع) ينظر : المرجع السابق صد . . . . }
\end{aligned}
$$


حوليت كليت اللغت العربيت بإيتاى البارود (العدد الثاني والثلاثون - المجلد الرابع) في صـحة الاستشـهاد بالقرآن الكريم، بل أجمـع العلمـاء القاصـي منهم والداني علي أن نصسوص القرآن الكريم هـي الينبوع الأول، والمصسدر الأساسـي في تقعيد اللغة، فهو كتاب الله المنزل بلغة عربية سليمة قال تعالي: [إنَّا أَنْزَنْـاهُ

قُرْأَنَا عَرَبِيًا]] [يوسف: ب]، وقد عدوه في أعلي درجات الفصاحة والبيان ('). يقول الد كتور أحمد مختار عمر نقلاً عن الراغب الأصمهاخي:(ألفاظ القرآن الكريم هي لب كلام العرب وزبدته، وواسطته، وكرائمه، وعليها اعتماد الفقهاء والحكماء، وإليها مفزع حذاق الثعراء والبلغاء، وما عداها كالقشور والنوي، بالإضافة إلي أطايب الثمرة)(؟). ولا جدال في أن الزجاجي يعد الثـاهد القرآني هو الأسـاس الأول، والمصدر الموثوق به في التقعيد، واستخلاص قواعد النحو، وتثبيتها. وكذلك استشهد بالقراءات القرآنية الكريمة ؛ لأنها الوجوه المختلفة التي

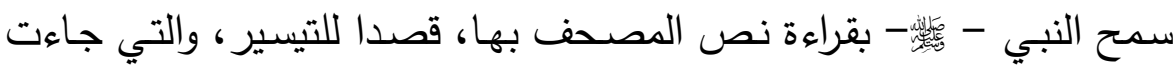
وفقاً للهجة من اللهجات العربية، يقول الإمام السيوطي:(أما القرآن فكل ما ورد أنه قرئ به جاز الاحتجاج به في اللغة العربية سواء كان متواتراً أم آحاداً أم شاذاً، وقد أطبق الناس علي الاحتجاج بالقراءات الشاذة في العربية إذا لم تخالف قياساً معروفاً، بل لو خالفته يحتج بها في مثل أل أرول

ذلك الحرف بعينه، وإن لم يجز القياس عليه).(r) وبيين ابن الجزري شروط القراءة الصحيـحت فيقولة-

(1) ينظر : في اللهجات العربية للدكتور : إبراهيم أنيس صـ 9؟، ويراجع: البحث اللغوي عند

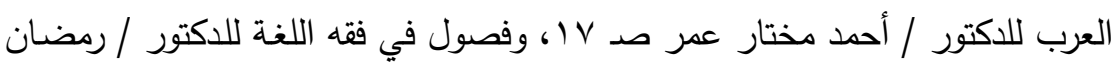
عبد التواب صـ V ، واللهجات العربية في التراث للدكتور / أحمد علم الدين الجندي صد ب. 1.

(Y) ينظر : البحث اللغوي عند العرب للدكتور / أحمد مختار عمر صـ 11) (r) ينظر : الاقتراح للسيوطي صـ بس. 


\section{دراسة موازنة بين منسجي الزجاجي وابن الفخار في تترح الجمل}

حوليت كليت اللغت العربيت بإيتاى البارود (العدد الثاني والثلاثون - المجلد الرابع)

(كل قراءة وافقت العربية ولو بوجه،، ووافقت أحد المصساحف العثمانية

ولو احتمالاً وصح سندها فهي القراءة الصحيحة التي لا يجوز ردها، ولا يحل إنكارها، بل هي من الأحرف السبعة التي نزل بها القرآن ووجب قبولها، سواء أكانت عن الأئمسة السبعة أم عن العشرة أم عن غيرهم من الأئمـة المقبولين، ومتي اختل واحد مـن هذه الأركان الثلاثة أطلق عليها ضـعيفة أو شـاذة أو أو أوهن باطلة سواء أكانت عن السبعة أم عمن هو أكثر منهم، هذا هو الصحيح عند أئمة التحقيق من السلف والخلف)('). فـالقراءة سـنة متبعـة، والقـراء لا يـأتون بشـيء مـن عندهم، بـل يلتزمـون بما نزل علي النبي - ثلئلة وهم لا ينظرون في القرآن: (علي الأفثي في اللغة والأقيس في العربية، بل علي الأثبت في الأثر، والأصسح في النقل، والرواية إذا ثبتت عنهم لم يردها قياس عربية، ولا فشو لغة، لأن القراءة سنة متبعة يلزم قبولها والمصير إليها)(ب). وأُقول: قد بلـغ عدد مـا استشهـ بـه الزجاجي في كتاب (الجمل) من الآيات القرآنية: مائة وتسع وعشرون آية ( و ب آية)، وهذا عدد ليس بالقليل. وقد استشهد أيضا بالقراءات القرآنية المختلفة، ومن شواهد ذلك قوله:(وقد قرأت القراء: [وَغِـيضَ المَـاءُ] [ هود: ؛ ؟ـ بالكسر وعليها أكثر القراء، وقرأ بعضههم بالإشمام، وهذا لا يضبط، وفيه لغة ثالثة لم تجئ في القـرآن لشـذوذها وقلتها...)(ז) وغيـر ذلك من القراءات القرآنيـة المـذكورة في

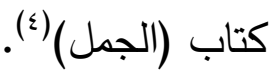

(1) ينظر : النشر في القراءات العشر لابن الجزري / 9/.

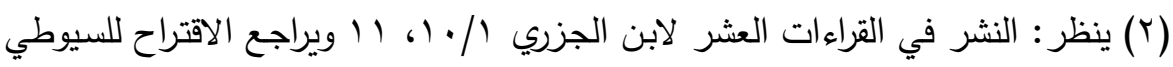
صد 10 .

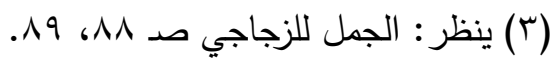

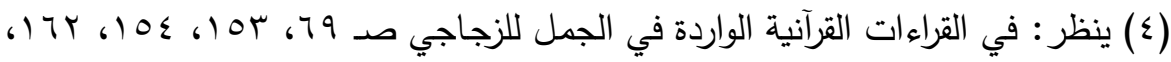

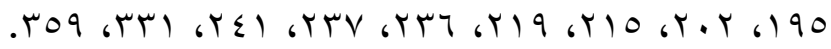


حوليت كليت اللغت العربيت بإيتاى البارود (العدد الثاني والثلاثون - المجلد الرابع)

وكذللك استثهد ابن الفخار بالقرآن الكريم، وقد بلغ عدد الآيات القرآنية

التي استشهر بها مائتين وأربع وخمسون آيـة (ع بـ آيـة)، وهذا العدد يقارب

ضعف العدد الذي استشهد به الزجاجي في كتابه (الجمل).

واستشهـ أيضـا ابن الفخار بالقراءات القرآنية المختلفة(1) في كتابه:

(شرح الجمل) متواترة أو شاذة، بل كان يذهب إلي ما هو أبعد من ذللك، وهو

تخريجه للقراءة الشاذة كما في قراءة أبي السمال في قوله تعالي: [إنَّكُمْ لَذَائقُو

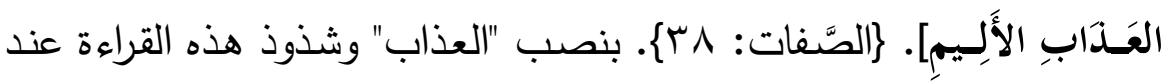

النحاة هو : نصب العذاب بعد حذف النون من اسم الفاعل، واسم الفاعل لا ينصب إلا إذا جرد من أل، وثبت فيه التتوين إن كان مغرداً، أو النون إن كان مثني أو مجموعاً جمعا سالماً، أما إذا لم يثبت التتوين ولا النون، فإنه يتعين عندهم الإضـافة إلي ما بعده، هذا وجها شذوذ هذه القراءة فيما رواه الفارسي، عن أبي عثمان عن أبي زيد (r).

وقد خرج ابن الفخار هذه القراءة بما هو مبسوط في (شرح الجمل)(r) فليراجعها مَنْ شاء.

\section{الححل يث النبوي الشريف:-}

يعد الحديث النبوي الثريف هو الأصل الثاني من أصول الاستثـهاد بعـد كـلام الله - يَّيَلْه وقد جـاءت السـنة مبنيـة للقـرآن الكـريم، وشـارحة لـه، فصلت موجزه، وقيدت مطلقه.

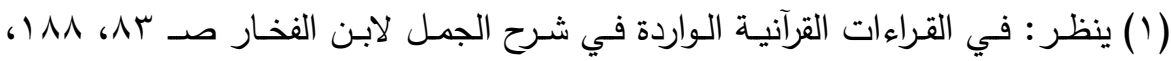
909 ، А وغيرها.

(Y) ينظر : الإيضـاح لأبي علي الفارسي صـ ، 10 ويراجع شرح الجمل لابن الفخار صـ . $\leqslant 0 \leqslant$ ، $\leqslant 04$ (r) ينظر : شرح الجمل لابن الفخار صـ سه؛، ؟0؟. 
حوليت كليت اللغت العربيت بإيتاى البارود (العدد الثاني والثلاثون - المجلد الرابع) أمسا عـن الاستثـهاد بالحديث النبـوي الثـريف، واعتبـاره مصـدراً مـن مصادر الاحتجاج في قضايا النحو والصرف فقد انقسم النحاة في ذلك إلي ثلاث فرق:

الأولي: منعت الاحتجاج به مطلقا، وعلي رأسها أبو حيان النحوي، وشيخه أبو الحسن بن الضـائع وإنمـا منـع هؤلاء الاحتجـاج بالحديث النبوي الشـريف لـيس لعـدم وقوفهم بصـحة سـنده ونحـو ذلك، وإنمـا لأن كثيراً مسن الأحاديث ليست من لفظ الرسول، وإنما هي منقولة بالمعني (')؛ ولوقوع اللحن في كثير مدا روي من الأحاديث ؛ لأن كثيراً من الرواة كانوا من الأعاجم والمولدين، وتكلموا العربية عن طريق صناعة النحو بمعني: أنهم ليسوا في عصور الاحتجاج.

الثانية: اتخذت مذهبا وسطاً وعلي رأسها الشاطبي والسيوطي. الثالثة: أجازت الاحتجاج به وعلي رأسها ابن مالك وابن خروف وابن

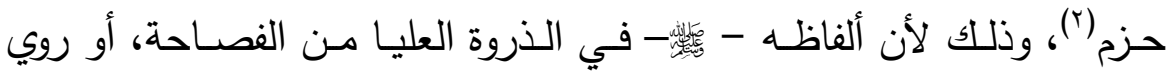
معناها بألفاظ الصحابة والتابعين، وهم داخلون في نطاق الاحتجاج. أما عن استشهاد الزجاجي في كتابه الجمل بالحديث النبوي الشريف، فإنه لم

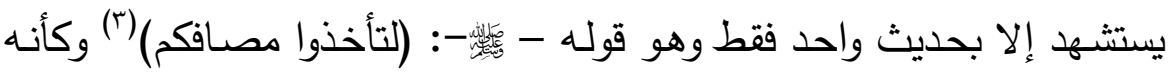
سـار علي نفس منهج قدامي النحاة الذين تركوا الاستدلال بالحديث النبوي الشريف؛ لأن روايته بـالمعني في كثير مـن الحـالات حجـه تبيح تركه وعدم الاستدلال به.

أمـا ابـن الفخـار فـي (شـرح الجمـل) فتـد استثـهـ بالحـديث النبـوي

الشريف، وكان عدد ما استشهد بـه سبعة عشر حديثا (V) حديثا) منها (T

(1) ينظر : الاقتراح للسيوطي صـ 17.

(Y) ينظر : ارتشاف الضرب لأبي حيان /9/9ء.

(r) ينظر : الجمل للزجاجي صد 7 آץ. 


\section{دراسة موازنة بين منسجي الزجاجي وابن الفخار في تترح الجمل}

حوليت كليت اللغت العربيت بإيتاى البارود (العدد الثاني والثلاثون - المجلد الرابع)

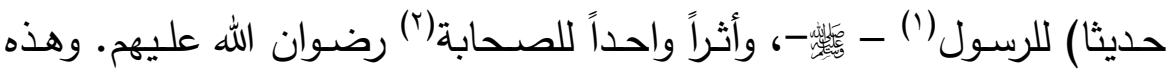
الأحاديث التي ذكرها ابن الفخار لا يري إطلاق الاستشهاد بها ودليل ذلك قوله: (... فالأظهر أن ذلك جائز في النثر علي قلة إن قلنا بصحة الاحتجاج

برواية المحدثين) (r)

\section{ج- الشواهد الشعريته-}

يعد الثـعر مـن أكبر المصـادر التي اسـتقي منهـا النحساة، قواعدهم النحويـة، حيث عكف النحاة علي هذا الموروث الثعري الضـخم يطالعونه، واستخدموه في ضنبط قوانين اللغـة، ومعرفة أصسولها، وضـوابطها الكلية في الأبنية والتراكيب، ولأن الشعر يمثل مختلف لغات العرب، وكان العلماء يرون أن لغات العرب كلها جديرة بالاعتبار ، ولا يصـح رد إحداها بالأخرى، ولكنهم لا يرون مانعا من تقوية إحدى اللغتين علي الأخرى إذا كان أقوي القياسين

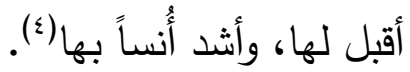

وقد تخصصست كلمـة شـاهد عند اللغويني، واعتبروهـا مقصسورة علي الشعر فقط؛ ولذلك نجد كتب الشواهد لا تحوي غير الشعر ، ولا تهتم بما عداه، حتي كان اللغويون يستشهدون بالشعر المجهول قائله إن صدر عن ثقة يعتمد عليه(0). وقد اهتم علماء اللغـة بتقسيم الثـراء الذين يحتج بشعرهم فقسموهم علي أربع طبقات:-

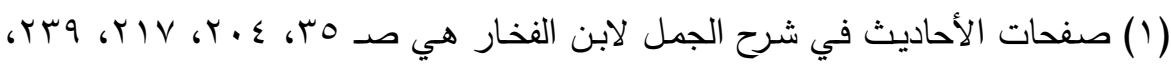

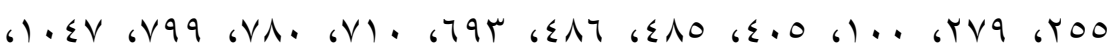
.1 .7161 .0 .

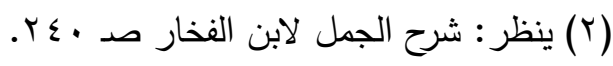

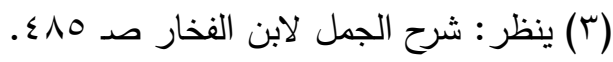

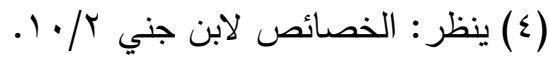
(0) ينظر : البحث اللغوي عند العرب للدكتور / أحمد مختار عمر صـ بـ. 
حوليت كليت اللغت العربيت بإيتاى البارود (العدد الثاني والثلاثون - المجلد الرابع) 1- الشعراء الجاهليون وهم الذين كانوا قبل الإسـلام كامرى القيس والأعشى، وزهير ، وطرفة، وعمرو بن كلثوم.

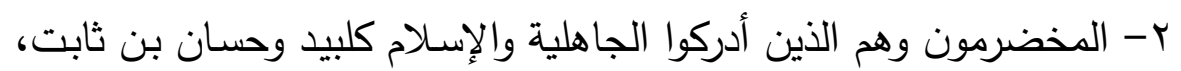

$$
\text { وكعب بن زهير - }
$$

ب - المتقدمون ويقـال لهم الإسـلاميون وهـم الذين كـانوا في صـدر الإسـلام

$$
\text { كجرير والفرزدق والأخطل. }
$$

ع- المولدون ويقال لهم المحدثون وهم يبدأون في العصر العباسي ببشار بن برد، وأبي نواس (') يقول أستاذنا الدكتور روضان عبد التواب:-

(وقـد أجمـع علمـاء اللغـة علي أن شعراء الطبقتين الأوليـين يحتج

بشعرهم بغير نزاع، أما الطبقة الثالثة فمعظم اللغوين يرون صحة الأخذ بشعر هذه الطبقة، غير أن بعضهم كان يأبي الاحتجاج به، وأما الطبقة الرابعة فقد رفض اللغويـون الاحتجاج بشيء من شعرها، فيما عدا الزمخشري الذي أجاز

ذلك)(r)

أمسا عن استثـهاد الزجاجي في كتابه (الجمل) بالشعر فإننا نجد أن

الزجاجي لم يكثر من الاستشهاد بالشعر، وقد بلـغ عدد الأبيات الشعرية التي

$$
\text { استشهد بها: مائة وواحد وستين بيتا من الثعر (17 (1 بيتاً). }
$$

والسـبب في ذلك: أنه كان يري أن الشعر باب ضـرورة، وقد صرح

بذللك في باب: "مـا يجوز تقديمـه من المضـر من الظاهر ومـا لا يجوز " قائلاً:

(.. وكان جـائزاً ؛ لأن الثـعر موضـع ضـرورة، فأمسا في الكـلام فـلا

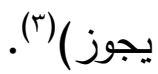

(1) ينظـر : خزانـة الأدب للبغـادي /0/0، 7، ويراجـع: فصـول في فقـه اللغـة للـكتور /

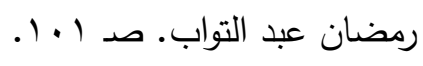

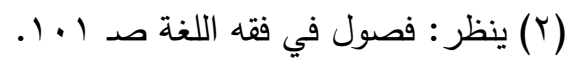

(r) ينظر : الجمل للزجاجي صـ اسا. 


\section{دراسة موازنة بين منسجي الزجاجي وابن الفخار في تترح الجمل}

حوليت كليت اللغت العربيت بإيتاى البارود (العدد الثاني والثلاثون - المجلد الرابع) ولم يختلف ابـن الفخـار في كتابه (شـرح الجمل) عن الزجـاجي مـن حيث الاستشهاد بالشعر فلم يكثر هو أيضـا من الاستشهاد بالشعر، وقد بلـغ عدد ما استثهد به من الأبيات الشعرية مائة وسبعة وستون بيتاً (TV ا بيتا)، وهذا العدد يزيد قليلاً عن العدد الذي استشهد به الزجاجي، وعلته في ذلك هي نفس العلة التي رآها الزجاجي قبله وهي: أن الثعر باب ضرورة، لا يستشهد به في مواضع السعة، وقد صرح بذللك قائلاً:

(إن الإثباع لا يكون إلا في الثعر المبني علي الضرائر)(').

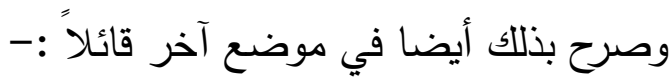
(.... واختصـاص ذلك بالثـعر مـح كثرة استعماله دليل علي أنه من

ضرائره)(r) (r)

** ثالث عشر:- من حيث المذهب النحوي، وموقف الزجـاجي وابن المخار من البصريين والكوفيين:كان الزجاجي ليس بالبصري المذهب المحض، ولا بالكوفي المذهب المحض، بل كن يذكر كلاً من مذهب البصرين والكوفيين ثم يصف أحدهما بما يدل علي تأييده للثاني، كأن يقول: (وإن قلت كذا كان قبيحا، وأهل البصرة لا لاجيزونه)

أو يذكر رأيه ثم يقول: (هذا هو الوجه الجيد)(؛).

وقد يعرض لأكثر من رأي، ثم يصنف الآراء تصنيفاً يسير فيه بحسب القوة والضـف في رأيه كأن يقول: (الأجود في هذا الباب كذا.... وبعد ذلك كذا.... ودون ذلك كله كذا...)(0).

$$
\begin{aligned}
& \text { (1) ينظر : شرح الجمل لابن الفخار صـ صـ. } \\
& \text { (Y) ينظر : شرح الجمل لابن الفخار صـ • ـ . 1. } \\
& \text { (r) ينظر : الجمل للزجاجي صـ (10) }
\end{aligned}
$$

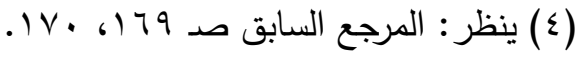

$$
\begin{aligned}
& \text { (0) ينظر : الجمل للزجاجي صد } 1 \text { اب. }
\end{aligned}
$$


حوليت كليت اللغت العربيت بإيتاى البارود (العدد الثاني والثلاثون - المجلد الرابع) * وإذا كان مذهب الزجاجي ليس بصريا خالصـاً، ولا كوفيا خالصـاً، وإنما كان ذا نزعة جديدة تمزج بين نحو البصرة ونحو الكوفة، تأخذ من كل محاسنهما، تاركاً العصبية المذهبية جانباً، إلا أنه كان يميل كثيراً إلي مذهب البصرين، بدليل أنه عد نفسه منهم فقال: (أصحابنا البصريون)(')، وقال أيضـا: (وليست هذه المسألة مسطرة لأصحابنا

في شيء من كتبهم ألبتة وهي مسطرة في كتب الكوفيين)(؟). ولعل ميل الزجاجي إلي المذهب البصـري يرجع إلي تأثيره بأستاذه المفضل، وشيخه الأول: (الزجاج) الذي كان بصري المذهب. وأقول: إن ميل الزجاجي إلي مذهب البصرين لم يحل دون استعماله مصطلحات الكوفيين بل هو علي العكس، فكان كثيراً ما يستعمل مصطلحات

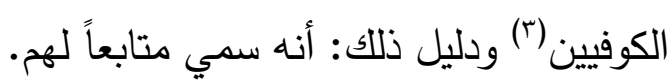

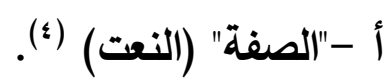
ب- "الثركة" ( عطف النسق)(•). ج- "نائب الفاعل" (اسم ما لم يسم فاعله)("). كما كان يبسط آراء الكوفيين، ويذكر أحسن احتجاجاتهم، ولا يغلظ لهم

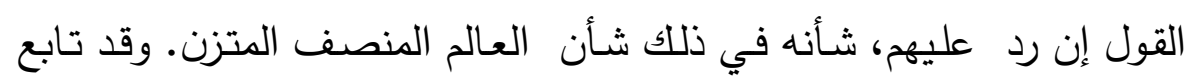
الزجاجي الكوفيين فذهب مذهبهم في أن (كأن) إذا كان خبرها اسماً جامداً كانـت للتشبيه مثل: - "كأن زيـداً أسـد"، واذا كان مشـتقاً كانـت للثـك بمنزلـة

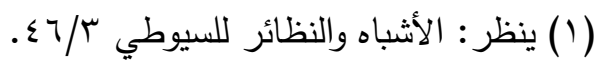
(Y) ينظر : المرجع السابق نفس الجزء والصفحة.

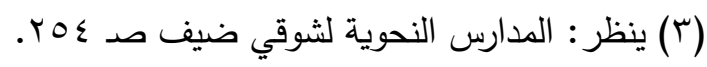

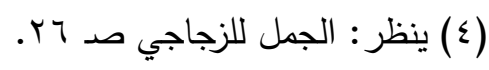
(0) ينظر : المرجع السابق صـ . بـ.

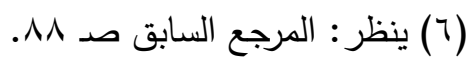




\section{دراسة موازنة بين منسجي الزجاجي وابن الفخار في تترح الجمل}

حوليت كليت اللغت العربيت بإيتاى البارود (العدد الثاني والثلاثون - المجلد الرابع) "ظننـ"، مثل: "كأن زيداً قائمُ"، وقد تأتي للتحقيق مثل قول الحارث بن خالد

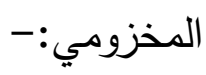

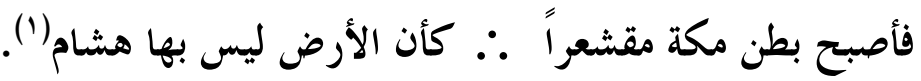

وكان البصريون يذهبون إلي أنها للتشبيه دائماً ولا معني لها سواه(r). وكـان الزجـاجي يكثر مـن التوقف بـازاء آراء البصـرين والكـوفيين محاولاً استتباط رأي جديد مسن ذلك: أن سيبويه كـان يذهب إلي أن (سـوي) ظرف مكان دائماً، وذهب الكوفيون إلي أنها ظرف متمكن يستعمل ظرفاً كثيراً وغير ظرف قليلاً.

أما الزجاجي فذهب إلي أنها ليست ظرفاً ألبتة، وأنها تقع فاعلاً في مثل: "جاء سوالك" ومفعولاً بهه مثل: "رأيت سوالك"، وبدلاً أو استثناء في مثل: "ما جاءني أحد سواك"، أي أنه يجوز فيها حينئذ الرفع علي البدلية، والنصب ولب ولهوله علي الاستثناء (r). ** أمـا عـن مـذهب ابـن الفخـار النحـوي، وموقفـه مـن البصـرين والكوفيين فـلا يختلف كثيراً عن مذهب الزجاجي، فكان ابن الفخار بصسري المذهب، يحكي كلاً من مذهب البصرين والكوفيين، لكنه كان في الغالب يرجح مذهب البصرين، بل ويدافع عن أئمة المذهب البصري، وينتصر لهم وفي (شرح الجمل) لابن الفخار كثير من المسائل التي حدث فيها خلاف بين البصرين والكوفيين لكن ابن الفخار وقف موقف المنتصرر للبصرين، ومن

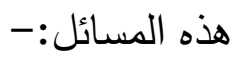

(1) البيت مـن الـوافر للحسارث بـن خالـد في ديوانـه صـ سوه، وبـلا نسبة في شـرح جمل

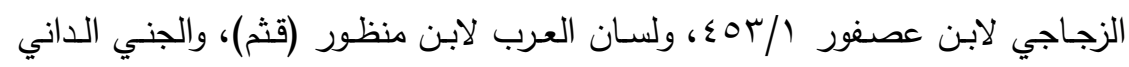

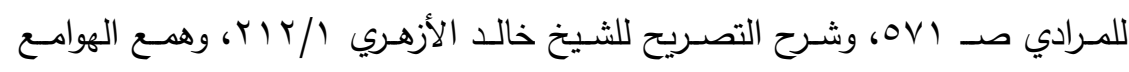

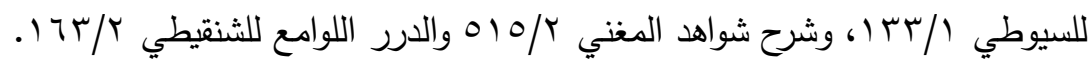

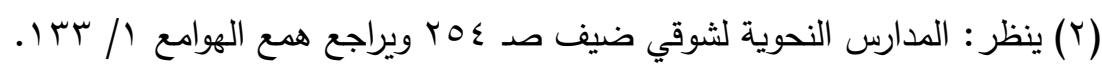

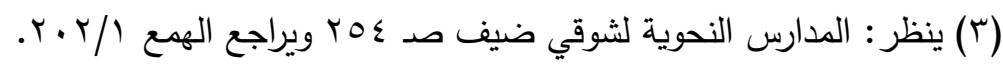




\section{دراسة موازنة بين منسجي الزجاجي وابن الفخار في تترح الجمل}

حوليت كليت اللغت العربيت بإيتاى البارود (العدد الثاني والثلاثون - المجلد الرابع)

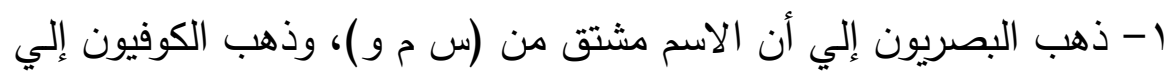

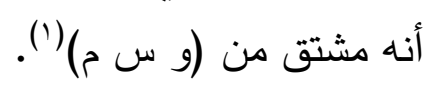

ץ- ذهب البصريون إلي أن الفعل مشتق من المصدر ، وذهب الكوفيون إلي

أن المصدر مشتق من الفعل(آ).

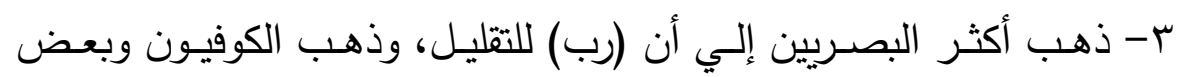

البصريين إلي أنها للتكثير (ץ).

ع - ذهب البصريون وطائفة من الكوفيين إلي أن "نعم وبئس" فعلان، وذهب إنب

الفراء وطائفة من الكوفيين إلي أنهما اسمان (£).

ه - ذهــب البصـريون إلـي منـع جمـع تمييـز "كــم" الاسـتفهامية، وأجـازه

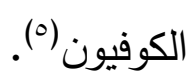

وهنالك مسـائل أخري(؟) كثيرة رجح فيها ابن الفخـار في (شرح الجمل) مذهب البصرين غير هذه المسائل.

* رابع عشر : من حيث اعتماد الزجاجي وابن الفنخار علي المصادرة:-

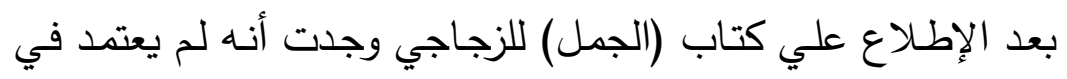
كتابه علي شيء من المصـادر إلا علي مصدر واحد هو (الكتاب) لسييويه، ولم يعتمد علي مصادر أخري غيره حتى أنه صرح بذلك في كتاب (الجمل) قائلاً:

$$
\begin{aligned}
& \text { (1) ينظر : شرح الجمل لابن الفخار صـ ع. }
\end{aligned}
$$

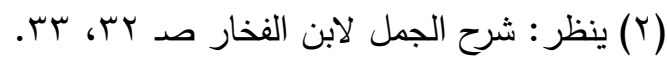

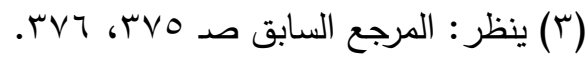

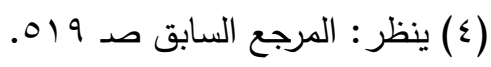

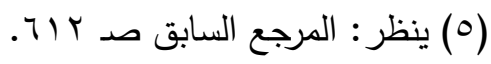

(T) ينظر : في المسائل الأخرى التي رجح فيها ابن الفخار مذهب البصريين: شرح الجمل

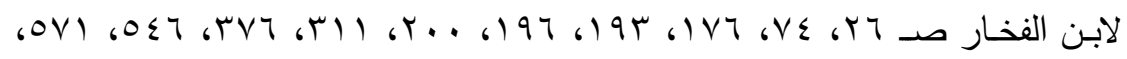

$$
\text { .90. ،V0. 6VYr ، T. . 090 }
$$




\section{دراسة موازنة بين منسجي الزجاجي وابن الفخار في تترح الجمل}

حوليت كليت اللغت العربيت بإيتاى البارود (العدد الثاني والثلاثون - المجلد الرابع)

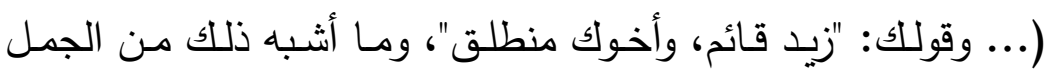

المحكية فلا تثني ولا تجمع ولا ترخم، وهكذا حكم جميع ما يحكي، وهذا قول

سيبويه، وجميع البصريين، وهو مسطور في كتابه في باب الحكاية (جr ص ول

ع 7) ولا أعرف للكوفيين فيه خلافاً أن المسمي. بها لا يثني ولا يجمع)(').

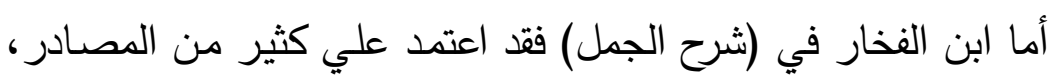

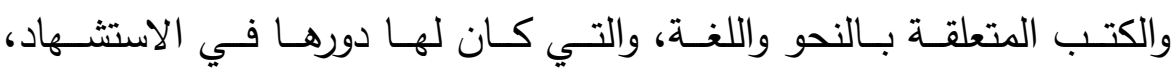

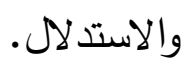

ومن هنا فإن ابن الفخار قد استفاد من هذه الكتب، وأحسن الاختيار

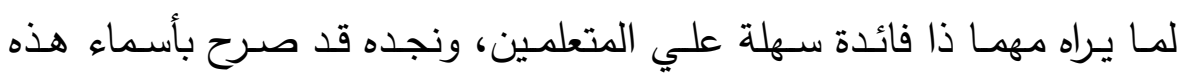

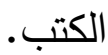

وسأذكر - إن شاء الله - هذه الكتب والمصادر مرتبة أبجدياً، وأشير

إلي صفحاتها من (شرح الجمل) في الحاشية، وذلك علي النحو التالي:-

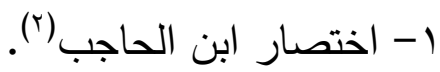

r- الأسئلة لأبي علي الشلوبين آنان.

r- الأصول لابن السراج (ء).

ع- الإيضاح لأبي علي الفارسي(ان.).

0- بعض تقاليد ابن أبي الربيع(؟).

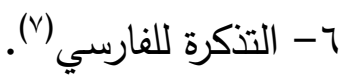

(1) (1) ينظر : الجمل للزجاجي صـ Orr.

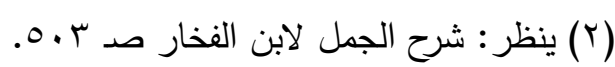

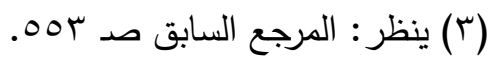

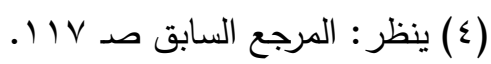

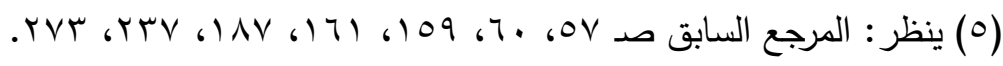

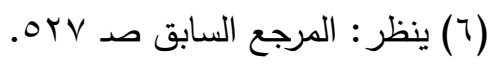

(V) 
حوليت كليت اللغت العربيت بإيتاى البارود (العدد الثاني والثلاثون - المجلد الرابع)

- التعاليق فيما قيد عن أبي علي الثلوبين (').

م- تقييد أبي الحسن الصغير علي المدونة (r).

9- التلخيص (r).

• 1- الدرة الألفية لابن معطي (؛). 11 - شرح الإيضاح لابن أبي الربيع('). r ا شرح الكتاب لأبي بكر بن عبيدة(؟). rا - الصحاح للجوهري (). ء ا - العين للخليل بن أحمد(^). 1 - القوانين لابن أبي الربيع('). 7 1 - كتاب آخر للزجاجي (·'). 1V 1 1 - الكراسة الجزولية(r').

(1) ينظر : شرح الجمل لابن الفخار صـ ץ. r.

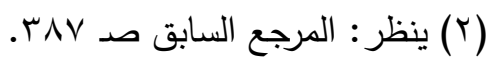

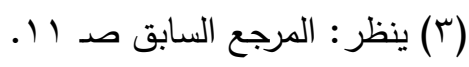

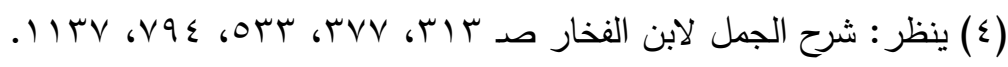

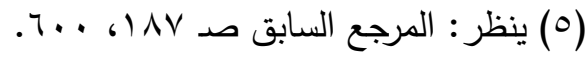

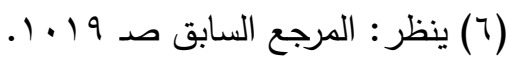

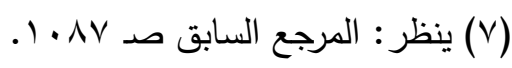

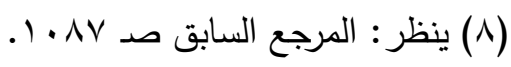

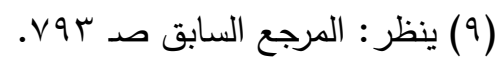

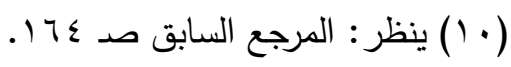

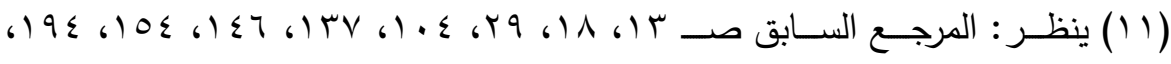

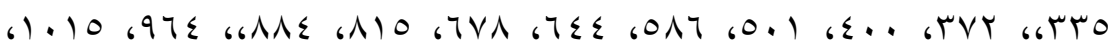
.11 ro 6) 111115

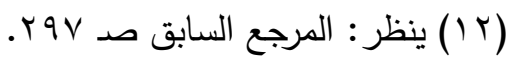


حوليت كليت اللغت العربيت بإيتاى البارود (العدد الثاني والثلاثون - المجلد الرابع)

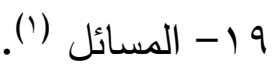

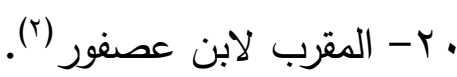

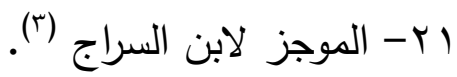

r r- الهلالية لابن عصفور (؛).

هذه هي مجموع الكتب التي ذكرها ابن الفخار ، علماً بأن هناك آراء

كثيرة لكثير من العلماء نص علي أسمائهم دون أن يذكر مؤلفاتهم التي نقل

منها

أ- فقد ذكر المبرد كثيراً ، وأغلب ما يذكره عنه نجده "في المقتضب"(0). ب- وممن نقل عنهم أيضـا الفارسـي، فقد نقل من: "المسـئل البصـريات"(")، وكذللك من "كتاب الشعر "(v)، ولم يشر إلي هذين الكتابين.

ج- وممن نقل عنهم ابن جني، وقد نقل عنه من: "الخصائص"(^). د - ونقل عن أبي الحسن بن خروف من: "شرح الجمل"(9) خاصة عند شرح بعض الأبيات واعرابها.

هـ- ونقل عن الزخشري من: "الكشاف"(·)") وكذلك من: "المفصل"(')".

(1) ينظر : شرح الجمل لابن الفخار صدV • 9.

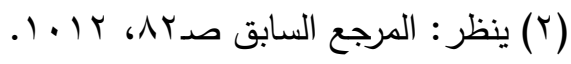

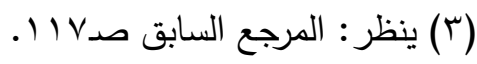

(ع) ينظر : المرجع السابق صـ r ا • ا.

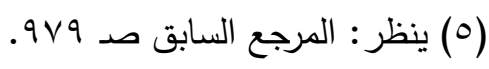

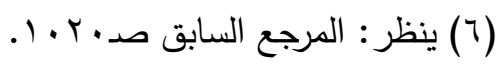

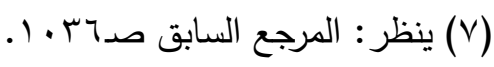

(^) ينظر : المرجع السابق صدم؟؟؟.

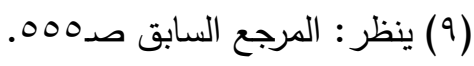

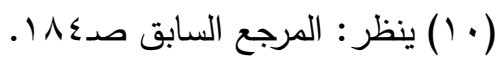

(1) ينظر : المرجع السابق صده . ب. (1) 


\section{دراسة موازنة بين منسجي الزجاجي وابن الفخار في تترح الجمل}

حوليت كليت اللغت العربيت بإيتاى البارود (العدد الثاني والثلاثون - المجلد الرابع)

و - ونتـل عـن ابـن الحاجـب مسن كتابـهـ المســى :الإيضــاح في شـرح

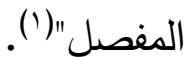

ز - ونقـل عـن ابـن مالـك وقـد أكثر مسن أخـذه مسن: "ثـرح التســيل"(؟).

ح- ونقل عن الآبذي، وقد نقل عنه من:" شرح الجزولية"(r). هذه أكثر المصادر التي استفاد منها ابن الفخار وغيرها، وكان لها أثرها في الي

$$
\text { كتابه (شرح الجمل). }
$$

\section{*خامس عشر:- من حيـث موقف الزجاجي وابن الفخـار مـن السـماع}

والقياس:-

من خلال معرفة مذهب الزجاجي النحوي تبين أنه كان يميل كثيرا إلي

مذهب البصرين بدليل أنه عد نفسه منهم فقال: (أصحابنا البصريون)(؛). وأقول: قد جري الزجاجي في السـماع علي الأسـاس الذي وضـعته المدرسـة البصرية وهو: النقل عن القراء للذكر الحكيم، ونْبِع الأخذ عن أفواه العرب الخلص الذين يوثق بفصـاحتهم، وكان البصـريون قد اشترطوا وحددوا عمن يأخذون اللغـة, وقيدوا ذلك بالقبائل البدويـة التي حافظت، وكانت بعيدة كل البعد عن مخالطة الحواضر والعجم وحددوها بأسد وتميم وقيس، بل وأخدوا من هذيل، وبعض كنانة، وبعض الطائين فقد أخذوا عن هؤلاء الشعر والنثر . وقد روي أن الكسائي أعجبه علم الخليل، فسأله من أين علمك ؟ فأجابه: "من

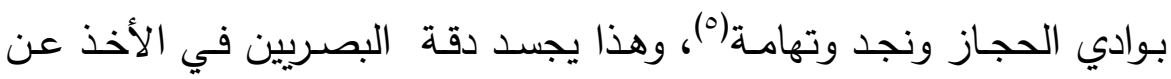
القبائل العربية الخالصة البداوة، وهم يتفاخرون في ذلك.

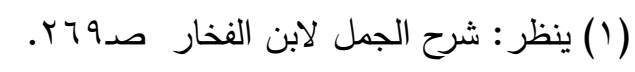

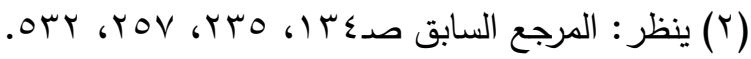

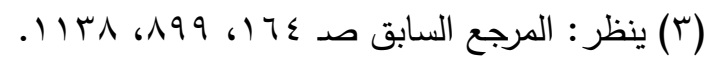

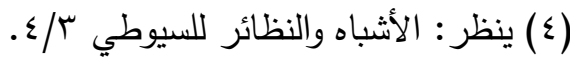

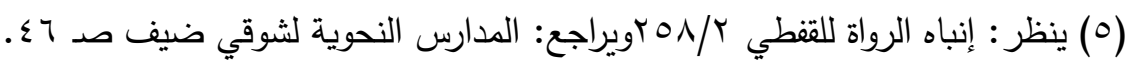




\section{دراسة موازنة بين منسجي الزجاجهي وابن الفخار في تترح الجمل}

حوليت كليت اللغت العربيت بإيتاى البارود (العدد الثاني والثلاثون - المجلد الرابع) ويدلل عليه قول الرياشي: (نحن نأخذ اللغة عن حرشة الضباب، واكله اليرابيـع، وهـؤلاء أخـذوا اللغــة عـنـ أهـل السـواد أصـــاب الكـواميخ، وأكلـة

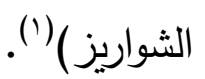

ومما يؤكد ذلك: أنهم كانوا لا يروون إلا من يثقون بهم كل الثقة ؛

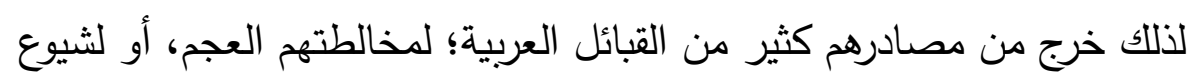
اللحن فيه.

كما استن الزجـاجي بالمدرسـة البصـرية في قلـة الاستثـهاد بالحديث

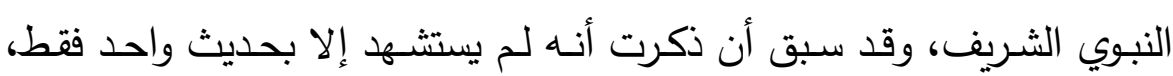
وذلك يرجح عند هؤلاء البصـرين من أن الحديث روي بـالمعني لا بـاللفظ، ودخل في روايته كثيرون من الأعاجم الذين لا يؤمنون علي اللحن. هذا بالنسـبة لجانـب السـماع، أمـا جانـب القياس فقد جري الزجاجي أيضاً علي الأسـاس الذي وضعته المدرسة البصرية، وهو أنهم: اعتمدوا علي أسس عقلية منطقية، فكانوا لا يقيسون إلا علي الكثرة المطردة، وأغفلوا جانب الب القلة والشذوذ.

حتي أنهم كانوا يقفون مع القليل والشاذ بالتأويل والتعليل حتي ينقاد مع أقيستهم المطردة، وقد عرف عن البصـرين ولعهم بالقياس ودليل ذلك قول الزبيدي: (إن أول من بعج -فتق - النحو ومد القياس، وشرح العلل هو عبد الله بن أبي إسحاق) (ז). وروي السيرافي أيضسا: (كان الخليل الغاية في استخراج النحو ، وتصحيح القياس فيه)(r).

إذن: لما كان الزجاجي يميل إلي مذهب البصريين كثيراً حتى أنه كان يسـلك نفسـه ويعدها في البصـرين فهو يجـري في السـماع والقياس علي

(1) ينظر : أخبار النحويين البصرين ومراتبهم للسيرافي صـ 99. (Y) ينظر : طبقات النحويين واللغوين للزبيدي صـ ابـ ويراجع: المدارس النحوية لشوقي

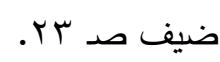
(r) ينظر : أخبار النحوين البصرين ومراتبهم صـ عـ. 
حوليت كليت اللغت العربيت بإيتاى البارود (العدد الثاني والثلاثون - المجلد الرابع) الأسـاس الذي وضـته المدرسـة البصـرية وهو: تقديم السـماع علي القيـاس، والقياس علي الكثير الغالب المطرد لا علي القليل والنادر . - أمـا موقف ابـن الفخـار مـن السـماع والقيـاس فهو لا يختلف عن موقف لـ الزجاجي ؛ لأن ابن الفخار - كما ذكرت سابقاً - كان بصري المذهب؛ وذلك لدفاعه عن أئمة المذهب البصري، والانتصار لهم غالباً. وإذا كان شـأن ابن الفخار كذلك فهو كالزجاجي: يقدم السماع علي القياس، وأن القياس لا معني عنده مـع وجود السماع، وأنه كان يقيس علي الكثير والغالب، ولا يعول علي القليل والنادر •

وهذا واضـح جلي من خلال الحديث عن الشواهد عند الزجاجي وابن الفخار والدليل أنهم كانوا يقدمون السماع علي القياس: أن الزجاجي استثهد بـ

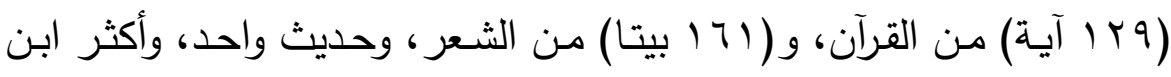
الفخار مـن ذلك فقد استشـهد ب (צ ب آيـة) مـن القرآن، و (VV ا بيتا) من الثعر ، و (V) حديثا)، ثم يأتي القياس بعد ذللك عندهما.

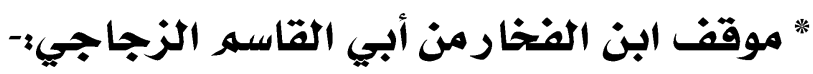

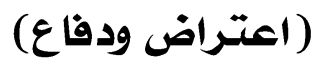

لمـا كان شرح ابن الفخار يتـاول كتاب (الجمل) للزجـاجي، فإنـه من الطبيعي أن نجد شيئاً فيه مما يتعرض فيه لأبي القاسم الزجاجي، سواء كان هذا التعرض دفاعاً عنـه أو مؤاخذة لـه، لا سيما أن هذا الشرح من المؤلفات المتأخرة التي تعرضــت للجمـل، فقد سـبقه عـد كبيـر مـن الثـروح المطولـة وغيرهـا، وسبقه أيضـا كتب اعتتات بالرد علي أبي القاسم الزجاجي أو الدفاع عنه نحو: "إصـلاح الخلل الواقع في الجمل" لابـن السـيد البطليوسي، وتـلاه كتاب:" الاعتراض والانفصسال فيما نسب فيه صساحب الجمل إلي الاختلل " لكأستاذ أبي علي الثلوبين. وهنا أذكر اعتراضات ابن الفخار علي أبي القاسم الزجاجي، وكذلك دفاع ابن الفخار عنه. 


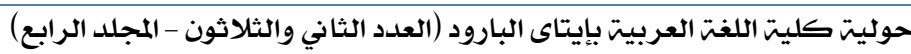

* أولاً: - اعتراضات ابن الفخار علي أبي القاسهر الزجاجي:لابد من التتبيه علي أن ابن الفخار قد استفاد كثيراً من ابن السيد في كتابـه، وهنـاك علمـاء آخـرون قد اسـتفاد مـنهم ابـن الفخـار كالسـهيلى وابـن الضائع وإليك نماذج من تلك الاعتراضات التي اعترض بها ابن الفخار علي

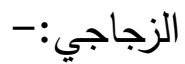

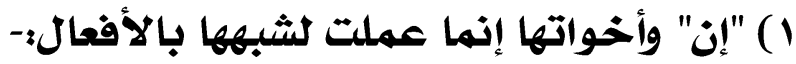

ذكر أبو القاسم الزجاجي أن "إن" وأخواتها إنما نصبت الاسم ورفعت الخبر ؛ لأن هذه الحروف أشبهت الأفعال المتعدية إلي واحد من خمسة أوجه: أ - أن معاني هذه الحروف كمعاني الأفعال فمنها ما هو للتوكيد، ومنها ما هو للتشبيه، ومنها ما هو للترجي، ومنها ما هو للاستدراك. ب- أن هذه الحروف أواخرها كلها مفتوحة. ج- أن عدد أحرف هذه الحروف كعدد أحرف الأفعال، فمنها الثلاثي والرباعي والخماسي.

د- أنها تطلب اسمين من جهتين مختلفتين، فهي تطلب الخبر ؛ لأنها إنما سيقت لتوكيده أو لتمنيه أو غير ذلك. ذ - أنها يتصل بها الضمير المنصوب كما يتصل بالفعل فتقول: إنلك، وإنه، وإني كما تقول: ضربك، وضربه، وضربني، هذا كله توجيه أبي القاسم

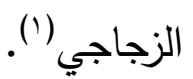

وهذا القول الذي قاله أبو القاسم، قد قال بأكثره المبرد حيث قال:(... وإنما أشبهتها؛ لأنها لا تقع إلا علي الأسماء، وفيها المعاني من الترجي والتمني والتشبيه التي عباراتها الأفعال، ولذلك بنيت أواخرها علي الفتح كبناء الواجب الماضي)(r)

(1) ينظر : الجمل للزجاجي صـ ع 17، 10.

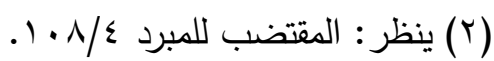


حوليت كليت اللغت العربيت بإيتاى البارود (العدد الثاني والثلاثون - المجلد الرابع) وقول أبي القاسم الزجاجي السـابق اعترضـه السـهيلي عدا الرابع منه، وهو اختصاصـها بالجملة الاسمية، وبقول السـهيلي قال ابن الفخار حيث قال السهيلي: (أمسا اتصال الضمير المنصوب بها فلم يكن إلا بعد حصول الشبه الموجـب للعمل، ولـولا ذلك لـم يتصـل بهـا، فـلا فـرق في هذا بين الضـمير

والظاهر في أن كل واحد منهما ثان عن الوجه الذي أوجب لها العمل)('). ثم قـال السـهيلي: (وأمـا الثلاثة الباقية فموجودة في حرف "ثم "ولم

يوجب لها ذلك شيئاً من العمل)(r). قـال ابـن الفخـار : (وأجـود مــا يقـال فـي ذلـك - ـو الله أعلـم - أن اختصاصسها بالجملة الاسمية هو الذي أوجب لها العمل، وأما الشبه المذكور فلم يوجب لها شيئاً و الله أعلم)(").

ץ - "عن " الجارة و"عن" المبل لن همزتها عيناً في بعض اللغات؛ذكر ابن الفخـار أن الزجاجي لـم يحرر اللفظ، ولم يثقف الكـلام من عروض الاشتراك اللفظي بين (عن) الخافضة، و (عن) المبدلة عينها من همزة أن المخففة في بعض اللغات فقال (لأن هذه - يعني الجارة - مسبوقة بأصل آخر ، وذلك أنك تقول: "أعجبني أن زيداً قائم"، ثم تخفف "أن" فتقول: "أعجبني أن زيداً قائم، بابقاه عملها لفظاً إن شئت، ثم تبدل من الهمزة عينـاً فتقول: "أعجبني عن زيداً قائم" وإن شئت: "أعجبني عن زيد قائم" بإهمالها لفظا دون

•) (عني) ץ- إعمال العامل الثثاخي والأول يطلب عمدة ذحو:

(1) ينظر : نتائج الفكر للسـهيلي صـ بـ ويراجع شرح الجمل لابن الفخـار صـ سبr، .

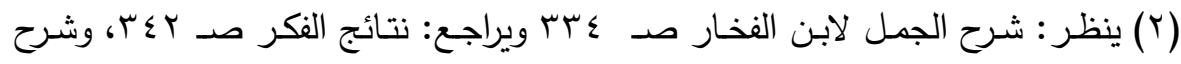

$$
\text { الشاطبي ع. •ـ. }
$$

(ץ) ينظر : المسألة بالتفصيل في شرح الجمل لابن الفخار صـ عبr.

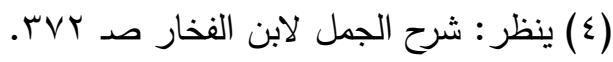




\section{دراسة موازنة بين منسجي الزجاجي وابن الفخار في تترح الجمل}

حوليت كليت اللغت العربيت بإيتاى البارود (العدد الثاني والثلاثون - المجلد الرابع) "ضـربوني وضـربت قومكت": اختلف النحساة في هذه المسـألة، فـالفراء يمنعها؛ لأنها إنما تجوز علي أحد وجهين:أ- إما علي حذف الفاعل من الفعل الأول، وهذا ممتتع لعدم النظير ، فالفاعل عمدة لا يصح الاستغناء عنه.

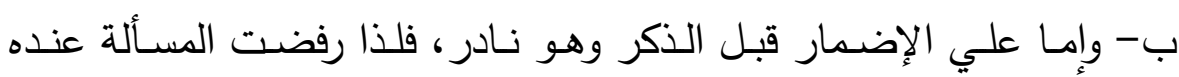
قياساً.

وأما الكسائي فإنه يجيزها علي حذف الفاعل وهو مراد في المعني. هذه صورة المسألة، وقد ذكر الزجاجي أن الكسائي قد غلط. قال ابن الفخار : (وليس قول أبي القاسـ: "وهذا غلط")(') برد صـيح؛ لأن الكسائي لم يرد ما أشار إليه أبو القاسم؛ لأن ظاهر قول أبي القاسم أن حذفه

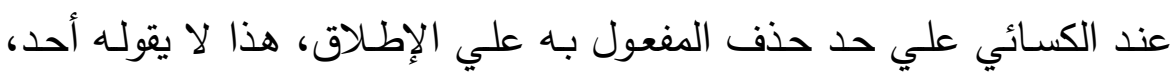
وإنما ينبغي أن يقال في المسألة: إن الفاعل إذا علم أضمر في سـائر أبواب العربية كقوللك: زيد قام، فالفاعل مضمر في: قام مع أنه معلوم بدلالة ظهوره في التثنية والجمع، والمبتدأ والخبر والمفعول به إذا عُلم حُذف ، فالفاعل في

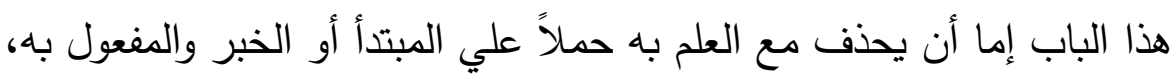
وإمـا أن يضمر مـع العلم بـه حمـلاً علي نفسه في سـائر أبواب العربية، وهذا أولي ؛ ليكون حيث مـا كان جاريـا علي أسلوب واحد، فهذا أرجح من قول الكسائي.

هكذا ينبغي أن يقال في ترجيح طريقة سيبويه علي طريقة الكسائي، لا

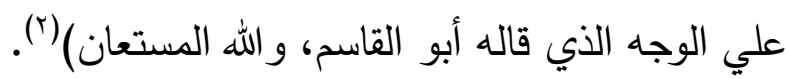

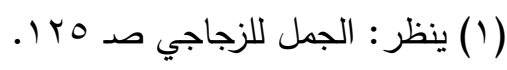

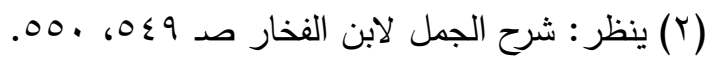




\section{دراسة موازنة بين منسجي الزجاجي وابن الفخار في تترح الجمل}

حوليت كليت اللغت العربيت بإيتاى البارود (العدد الثاني والثلاثون - المجلد الرابع)

هذه بعض النماذج مما اعترض به ابن الفخار علي أبي القاسم الزجاجي، وما اعترض بـه أكثر من هذا ولكن أشير إلي صفحات المواضع الأخرى(') التي وقع فيها اعتراض من ابن الفخار علي الزجاجي في الحاشية. ثانيا : دفاع ابن الفنخار عن أبي القاسهر الزجاجي:سبق ذكر بعض نماذج من اعتراضـات ابن الفخار علي أبي القاسم الزجاجي، وتلك الاعتراضـات وإن كانـت ردودا علي الزجاجي إلا أن بعضـها يتضـمن اعتذاراً، فـابن الفخار يغلب عليه التقدير والاحترام للزجاجي إذا رد كثيراً ممـا اعترض بهه عليه، وأذكر هنـا نمـاذج من تلك الردود ودفاعـه عن ين

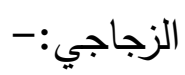

() قال أبـو القاسـم الزجـاجي: (اعلم أن الاسـم المبتدأ مرفوع.... والابتداء

معني رفعه، وهو مضارعته للفاعل)(r).

ب) قـال ابـن الفخـار : (قـد اعترضــه ابـن عصـفور بـوجهين أحدهما: أن المضـارعة معني، و المعاني لـم يثبت لها عمل الثاني: أن الأصسل لا يطرد حمله علي الفرع(r) فأجاب ابن الفخار عن هذا الاعتراض بقوله:الجواب عن الأول أنه قائل بأن التعـري يرفع المبتدأ أو الخبر فمـا

والجواب عن الثاني: أن الأصل يحمل علي الفرع، فما هو أصل في الفرع فرع في الأصل، وذا من ذلك، هذا إن سلمنا أن الجملة الاسمية أصل للفعلية، وفيه نظر ، إذ لقائل أن يقول: إن ذلك بالعكس، وقد قيل: إنما يستقيم

(1) الصفحات التي ورد فيها اعتراض من ابن الفخار علي أبي القاسم الزجاجي في شرح

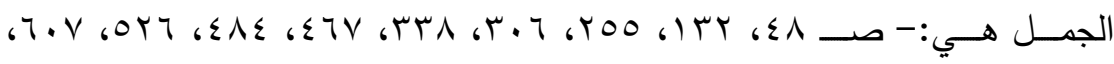

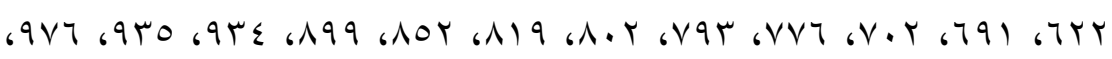

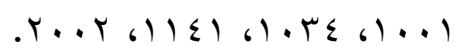

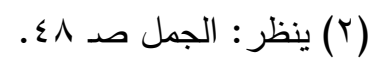
(r) ينظر : شرح الجمل لابن الفخار صـ ب7r. 


\section{دراسة موازنة بين منسجه الزجاجي وابن الفخار في تترح الجمل}

حوليت كليت اللغت العربيت بإيتاى البارود (العدد الثاني والثلاثون - المجلد الرابع) إفساد مذهب من المذاهب بأمر وقع إجماع المختلفين عليه ، فلم يصنع ابن

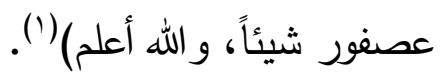

ب) قال أبو القاسم الزجاجي: (وأما ما لا ينصرف في المعرفة وينصرف في النكرة، فهو اثتا عشر جنسا... فمنها كل مؤنث علي أكثر من ثلاثة

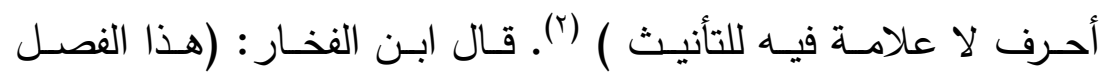
مخصوص بالمؤنث ؛ لأنه سيذكر فيما بعد فصل المذكر المسمي باسم مؤنث، فاعتراض ابن السيد عليه هنـا غير صحيح، وذلك أنه قال: لا يصح هذا الفصل حتي يزاد فيه شروط ! فيقال: كل مؤنث علي أكثر من ثلاثة أحرف لا علامة فيه للتأنيث، وليس أصله التذكير ، وتأنيثه حقيقي فحينئ ل اليصرف لمذكر كان أو مؤنث ظنا منه أنه يريد الإطلاق، وليس كذللك كما ذكرناه. وانظر إلي تسويته بين المؤنث والمذكر في تلك الشروط، فإنها تعطي أنه متي نقص منها شرط وهو علم لمؤنث فإنها ينصرف كما يكون كذلك وهو علم لمذكر ، وليس كذلك، وانظر أيضـا إلي قوله:" وتأنيثه حقيقي" فإنه يوهم اشـتراط أن يكـون المؤنـث لـه فـرج بـإزاء ذكـر اعتبـاراً بـالعرف الجـاري عند المعربين، وليس كذلك، وإنما يشـترط أن يكون التأنيث غير عارض كتأنيث

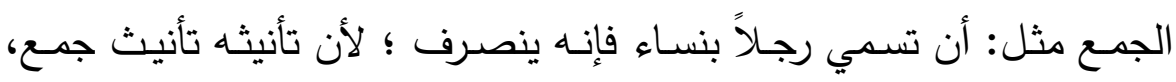
وهو عارض فلا تعتد به.

فالحاصل أن ابن السيد وهـ في هذا الأصسل الذي أصله في ثلاثة

$$
\text { أحدها: جعله المقيد مطلقاً }
$$

والثاني: تسويته بين المؤنث والمذكر في تلك الشروط.

(1) ينظر : المرجح السـابق نفس الصفحة - ويراجح: قول ابن عصفور في شرح الجمل

$$
\text { . } r \leqslant r \text {, } r \leq 1 / 1
$$$$
\text { (Y) ينظر : الجمل للزجاجي صـ مrr. }
$$ 
حوليت كليت اللغت العربيت بإيتاى البارود (العدد الثاني والثلاثون - المجلد الرابع) والثالث: اشتراطه في التأنيث أن يكون حقيقياً، غير أنه تحرز بهذا الثالث من التأنيث العارض، وإنما الخلل من جهة التعبير عن ذلك بما يعطي اشتراط المؤنث أن يكون له فرج بإزاء ذكر ، و الله أعلم ('). والذي ذكره ابن الفخار من أن اعتراض ابن السيد غير صحيح فيه شطط في بعض أجزائه، فقد ذكر أن ابن السيد جعل المقيد مطلقاً، ويعني بذلك أن كلام أبي القاسم مقيداً في هذا الفصل بما سيأتي في فصل المذكر المسمى بمؤنث، فما في هذا الفصل يقيد المطلق في الفصل السـابق هذا هو مراد ابن الفخار • - مراد

فكان عليه أن يترك هذا الاعتراض؛ لأن المسـائل في موضدوع واحد ويجب أن تكون في مكان واحد إلا إذا أشـار إليها المؤلف بـأن استعمالها سيأتي في موضـع آخر ، والزجاجي لم يقل ذلك هذا من ناحية، ومن ناحية أخري فـإن كتاب أبـي إسـاق هذا كتاب تعليهي والتعليم فيـه يجب مراعـاة الولدان، وقد قال بهذه المراعاة ابن الفخار في موضـع لاحق حيث قال في شأن الزجاجي: (.... لأنه في معرض تعليم الولدان، فالتقربب عليهم ما أمكن

₹) قال أبو القاسم: (وتقول في أسماء السور: هذه هود، وهذه يونس، تريد سورة هود وسورة يونس، فتصرف هوداً، فإن جعلت هوداً اسم سورة لم

\section{تصرفه؛ لأنك سميت مؤنثا بمذكر)(r)}

وقد اعترض ابن السيد إيراد الزجاجي لـ "يونس"؛ لأن يونس كما يقول ابن السيد؛ (لا ينصرف علي كل حال؛ لأنه إن كان علماً للسورة ففيه التعريف والتأنيث والعجمة، وإن كان علي حذف مضاف ففيه التعريف والعجمة)(؛).

$$
\begin{aligned}
& \text { (1) ينظر : شرح الجمل لابن الفخار صد با (9)، ؟ (9.9. }
\end{aligned}
$$

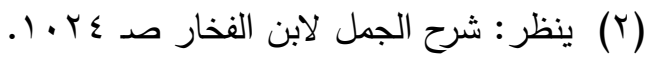

$$
\begin{aligned}
& \text { (r) ينظر : الجمل للزجاجي صـ rسץ. } \\
& \text { (ع) ينظر : قول ابن السيد في إصلاح الخلل صد .9 ؟. }
\end{aligned}
$$


حوليت كليت اللغت العربيت بإيتاى البارود (العدد الثاني والثلاثون - المجلد الرابع) وقد رد ابن الفخار هذا بقوله: (وهذا لا يلزم؛ لأنه يمكن أن يكون أبو القاسم إنما ذكره ليبين اختلاف هود في الوجهين، ولا يتصور ذلك الاختلاف في يونس، ولم يتعرض لبيانه: لظهور الأمر فيه و الله أعلم)('). هذه نمـاذج مـن ردود ودفـاع ابن الفخـار عن أبـي القاسـم الزجـاجي، وهناك ردود أخري من ابن الفخار عن الزجاجي أشير إلي بعض صفحات منها في الحاشية من كتابه "شرح الجمل".(؟)

[اتفاق وافتراق]

من خلال تلك الموازنة بين كل من الزجاجي في كتابه (الجمل)، وابن الفخـار في كتابـه (شـرح الجمل) تبـين أن بينهمـا مـواطن اتفـاق وهـي كثيـرة، ومواطن اختلاف وهي أقل، ويمكن لي توضيحها علي النحو التالي:أولاً : مواطن الاتمثاق بين الزجاجي وابن المخخارةا - بدأ الزجاجي وابـن الفخار بالبسملة، والصـلاة والسـلام علي رسـول الله -

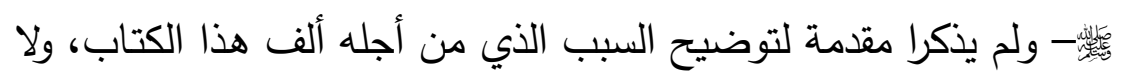

$$
\text { الاسم الذي سمي الكتاب به. }
$$

Y- حـرص الزجـاجي وابـن الفخـار علـي تصـحيح المصـطلحات النحويـة، وسلامة الحدود ودقتها وضبطها.

ب-ذكر الزجاجي وابن الفخار الخلافات النحوية التي تكون بين النحاة أحيانا في بعض المسائل.

ع-اعتي الزجاجي وابن الفخار بالتعليل وعولا عليه، فلم يذكر أحدهما قاعدة نحوية إلا وقد ذكر العلل والأسباب لها، وإن كان اهتمام ابن الفخار أكثر لكن كلا منهما لم يغفل تلك العلل.

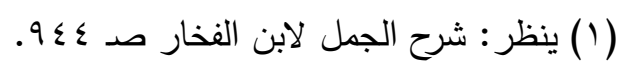

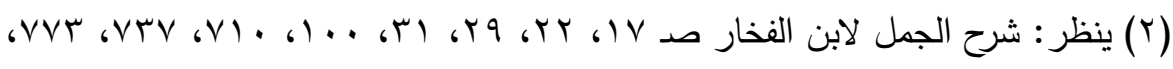




\section{دراسة موازنة بين منسجه الزجاجي وابن الفخار في تترح الجمل}

حوليت كليت اللغت العربيت بإيتاى البارود (العدد الثاني والثلاثون - المجلد الرابع)

0- اعتني الزجاجي وابن الفخار بذكر الاختيارات النحوية وإن كان اهتمام ابن الفخار أكثر من الزجاجي، لكنهما لم يغفلا تلك الاختيارات. צ- ذكر الزجاجي وابن الفخار مخالفتهما لبعض النحاة، وإن كان اهتمام ابن لهندان الفخار أكثر من الزجاجي لكنهما لم يغفلا تلك المخالفات.

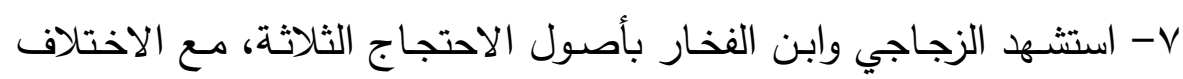
في عدد ما استشهدا به كما سبق. ^ - كان الزجاجي وابن الفخار يري أن الشعر باب ضـرورة، لا يستشهـ بـ به

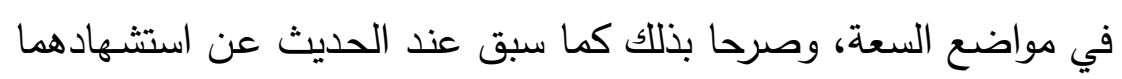
بالشعر .

9- كان الزجاجي وابن الفخار يميلان إلي المذهب البصري كثيرا، بدليل أن الزجاجي عد نفسه من البصريين، وكذلك ابن الفخار، بل دافع كل منهما عن أئعة المذهب البصري، بل وكان ينتصر لهم غالباً.

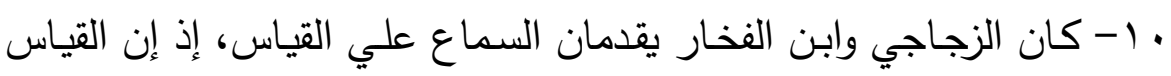
لا معني له عندهما مع وجود السماع، وكان القياس إنما هو علي الكثير

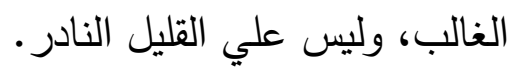

ثانيا :- مواطن الافتراق والاختلاف بين الزجاجي وابن الفخار وإن-

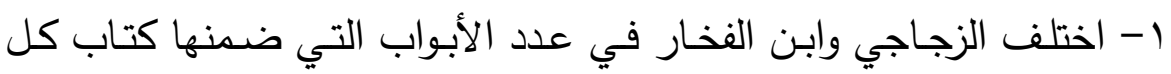

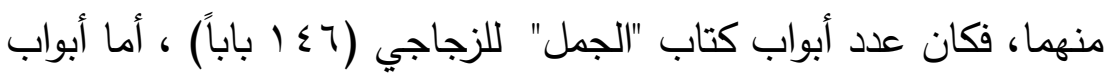
كتاب "شرح الجمل" لابن الفخار فكانت (ع د بابا) فقط.

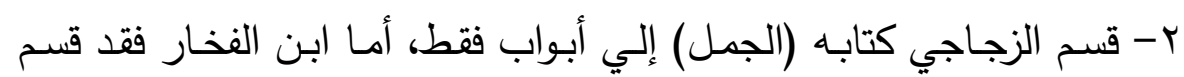

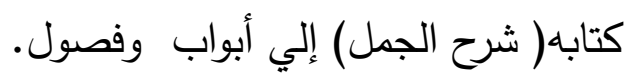
r - كان الزجاجي يذكر المسائل النحوية والصرفية فقط دون ربطها بالمسائل

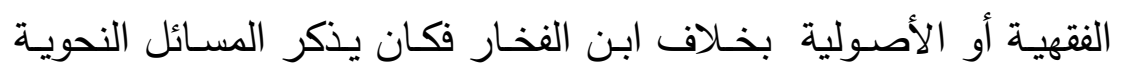
والصرفية ثم يذكر ما يترتب عليها من المسائل الفقهية أو الأصولية. 
حوليت كليت اللغت العربيت بإيتاى البارود (العدد الثاني والثلاثون - المجلد الرابع) ؟ - اقتصر الزجاجي في تعريفه للحدود علي الناحية الاصطلاحية فقط، دون ربطها بدلالتها اللغوية، بخـلاف ابن الفخـار فكان يربط الحدود بالناحية اللغوية مع الناحية الاصطلاحية كثيرا. 0- كان أسلوب الزجاجي في كتابه (الجمل) سهلاً ميسراً، بعيدا عن التعقيد،

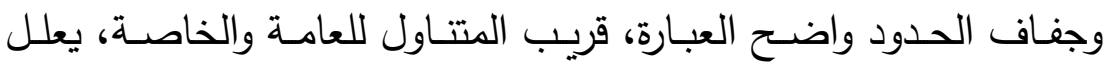
القواعد بأسلوب أدبي عذب بخلاف ابن الفخار في (شرح الجمل) فكان

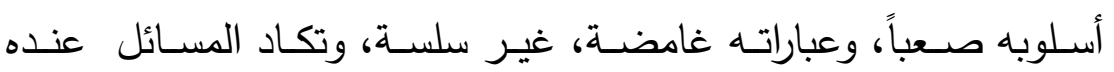
تستغلق علي الفهم، ولعل ذلك يرجع لأنه كان يورد المسائل ثم يعود إليها مرات أخري فيبسطها تحت عناوين كثيرة، وكأنه ألف كتابه هذا ثم عاد إليه مرات كثيرة وفي كل مرة يضيف إليه ما يراه إكمالاً له.

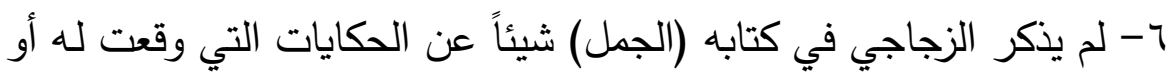

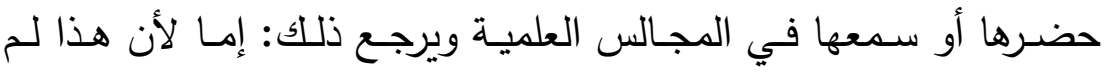
يحدث أصلاً، أو حدث ولم يذكره، بخلاف ابن الفخار في (شرح الجمل)

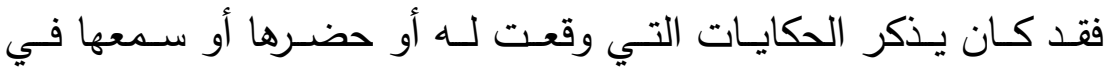
المجالس العلميـة في مواضـع متعددة من الكتاب، ولعل هذا الاختلاف راجعا لكون كتاب (الجمل) إنما هو متن، بخـلاف كتاب (شرح الجمل) فهو شرح لذاك المتن. V- بالنسـبة لاعتمـاد الزجـاجي وابـن الفخـار علـي المصـادر فهو مـوطن اختلاف لأن الزجاجي لم يعتمد في كتابه (الجمل) إلا علي مصدر واحد فقط هو : "الكتاب" لسيبويه بخلاف ابن الفخار فقد اعتمد في كتابه (شرح الجمـل) علـي مصـادر كثيـرة، سـواء ذكرهـا بأسـمائها صـراحة، أو ذكـر أصحابها ولم يذكر أسماء هذه الكتب. هذه أهـم مـواطن الاتفـاق والاختلاف بـين كل مـن الزجـاجي في كتابـه (الجمل) وابن الفخار في كتابه ( شرح الجمل). 


\section{الخخاتهمن}

الحمد لله رب العالمين، والصـلاة والسـلام علي نبيه المبلغ عنه بلسـان

عربي مبين.

\section{وبعل :-}

فإن هذه الدراسة كانت عبارة عن عقد موازنة بين كل من الزجاجي في

كتابه (الجمل)، وابن الفخار في كتابه (شرح الجمل)، وبعد تلك الدراسة أود أن

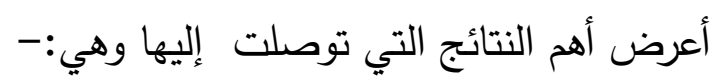

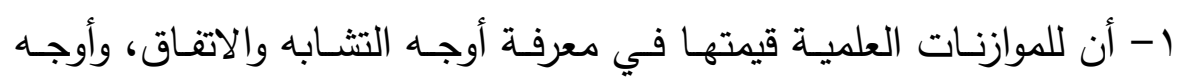
التباين والافتراق بين كل شيئين كما جاء ظاهراً في الموازنة بين (الجمل)

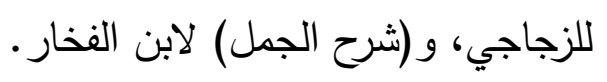

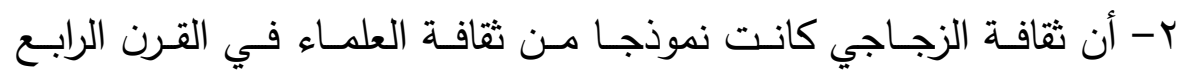
الهجري، ذاك القرن الذي حفل بنتاج خصب للعقلية الإسـامية في أوج

$$
\text { نضجها ورقيها. }
$$

ب- أن الزجـاجي كـان شـيد الولـع بـالعلم، فقد أكثر مـن الأخذ عن علمـاء عصره، وتخرج علي يده عدد من التلاميذ أكثرهم دمشقيون. ع - أن الزجاجي كان عارفا ببعض اللغات المعروفة في عصره، وقد صرح بذللك، لكنه لم يعين هذه اللغات. 0- أن الزجاجي كان قد أخذ من المدرستين البصـرية والكوفيـة، لكنه كـان كأستاذه الزجاج في الميل إلي المذهب البصري، لكن لم يمنعه ميله إلي

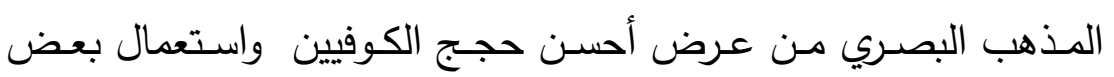
مصطلحاتهم.

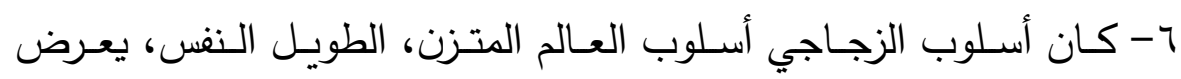
المسألة بإيجاز ، ويورد أحسن ما قيل فيها من الآراء والحجج، سالكا سبيل

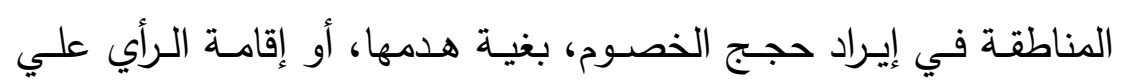
أنقاضها. 


\section{دراسة موازنة بين منسجه الزجاجي وابن الفخار في تترح الجمل}

حوليت كليت اللغت العربيت بإيتاى البارود (العدد الثاني والثلاثون - المجلد الرابع)

- امتاز الزجاجي في كتابه (الجمل) بالدقة والأمانـة في النقل والرواية، فلا يذكر شاهداً إلا معزوا إلي قائله.

1 - أثبت البحث أن كتاب (الجمل) للزجاجي له قيمته، حيث نال شهرة مدوية في العصـور الوسـطي، وقيمـة الكتـاب هذه هـي التي تفسـر لنـا هجوم العلماء علي شرحه، وازدحامهم علي الكتابة عنه. 9- يعد ابن الفخار من شراح (الجمل) وهو من علماء القرن الثامن الهجري المتميزين الذين أسهموا في دراسة النحو بجهود كبيرة كان من نتاجها ذاك الشرح.

• ا- يعـد ابن الفخـار علمـاً مـن أعـلام النحو، لكن قل أن يعرفـه أحد في عصرنا مع غزارة علمه.

11- امتاز كتاب (شـرح الجمـل) لابـن الفخـار بكثرة ذكر الأصـول والقواعد النحوية العامـة، مع كثرة التوجيهات الجلية، وذكر الأخبار والحكايات الطريفة التي تخلو منها كتب النحو. Y I - يعد (شرح الجمل) لابن الفخار من الشروح المطولة لكتاب (الجمل)، ومع ذلك فان مؤلفه قلل فيه من الاستشهاد بالشعر قلة ملفتة للنظر .

\section{الباحثن}

دكتورة / فاطمت عبد الرحمن عبل اللطيف الجندي 
دراسة موازنة بين منسجي الزجاجي وابن الفخار في تترح الجمل

حوليت كليت اللغت العربيت بإيتاى البارود (العدد الثاني والثلاثون - المجلد الرابع)

أولاً : فهرب الآيات القرآنيت

\begin{tabular}{|c|c|c|c|}
\hline الصفحة & رقم الآية & الآية & اسم السورة \\
\hline$r \leqslant 1 V$ & 197 & 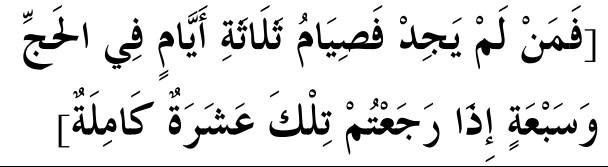 & \multirow{2}{*}{ البقرة } \\
\hline$r \varepsilon I V$ & rYA & 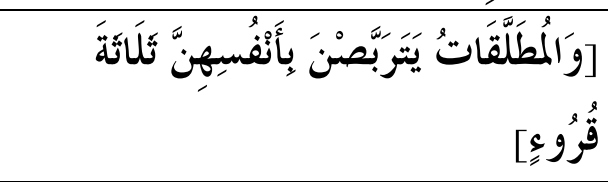 & \\
\hline$r \varepsilon \cdot v$ & 7 & 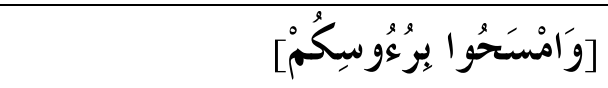 & المائدة \\
\hline$r \varepsilon . q$ & $1 \cdot 1$ & 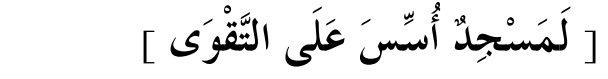 & 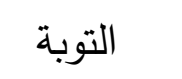 \\
\hline$r \leqslant r$. & $\varepsilon \varepsilon$ & D [وَغِيضَ المَاءُ ـ & \multirow[b]{2}{*}{ هود } \\
\hline$r \varepsilon .1$ & 01 & 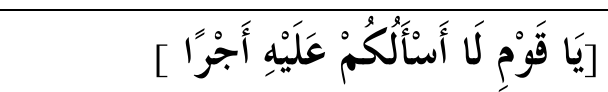 & \\
\hline$r \leqslant 19$ & r & D] & يوسف \\
\hline$r \leqslant Y)$ & rᄉ & 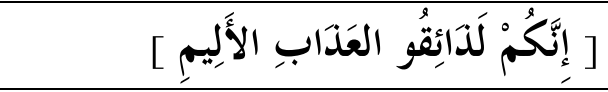 & الصافات \\
\hline
\end{tabular}

ثانياء فهرس الأحاديث النبويت الشريفتة.

\begin{tabular}{|c|c|}
\hline الصفحة & الحديث \\
\hline$r \leqslant Y r$ & لتأخذوا مصافكم. \\
\hline
\end{tabular}

ثالثا : فهرب الأبيات الشعريت

\begin{tabular}{|c|c|c|c|}
\hline الصفحة & القائل & البحر & البيت \\
\hline$r \leqslant r V$ & 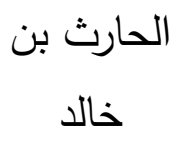 & الوافر & 1- فأصبح بطن مكة مقشعراً \\
\hline
\end{tabular}




\section{رابعا: فهرب أهم الهصادر والهراجع}

أولاً: المخطوطات:-

1- إثـارة التعيين إلـي تـراجم النحساة واللغـويين لأبسي المحاسـن عبد البـاقي

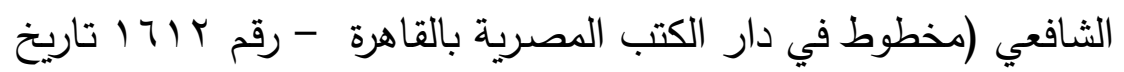

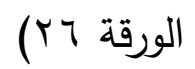

ץ- برنـامج المنتوري ، لأبي عبد الله محهد بـن عبد الله المنتوري - مصـورة

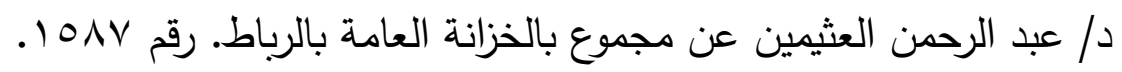

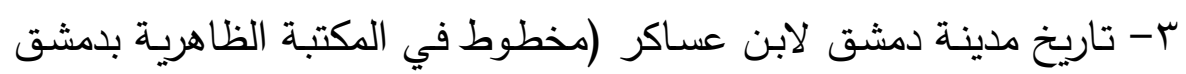

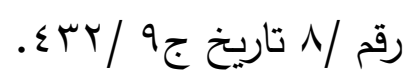

ع -عيون التواريخ لابن شاكر الكتبي ( مخطوط في دار الكتب بالقاهرة رقم

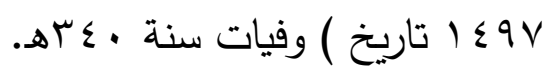

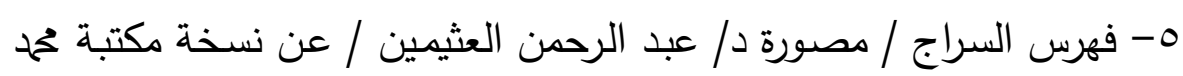

$$
\begin{aligned}
& \text { عبد الحي الكتاني - الخزانة العامة - الرباط. } \\
& \text { ثانيا: الرسائل العلمية:- }
\end{aligned}
$$

أبو عبد الله بن الفخار وجهوده في الدراسـات النحويـة مـع تحقيق كتابه النهابـ شـرح الجمل رسـالة دكتوراه - إعداد: حمـاد بن محمد حامد الثمالي إشراف

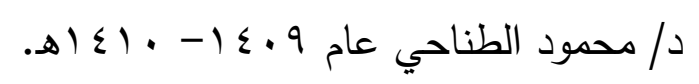

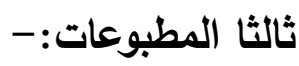

- الإحاطة في أخبار غرناطة لابن الخطيب تحقيق: عحم عبد الله عنان -

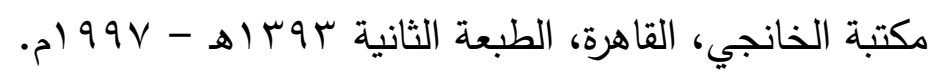

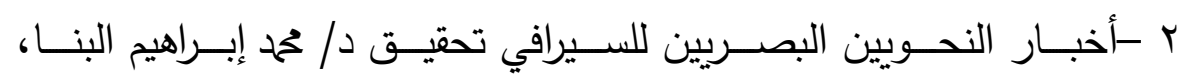

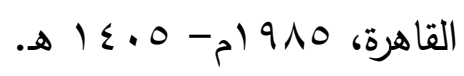

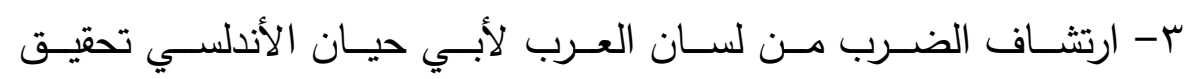

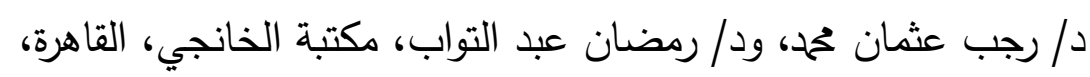

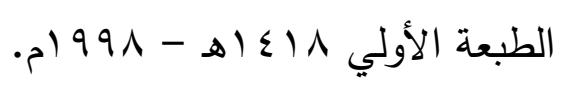


حوليت كليت اللغت العربيت بإيتاى البارود (العدد الثاني والثلاثون - المجلد الرابع) ع - الأشباه والنظائر في النحو للإمـام جلال الدين السيوطي، ط: دار الكتب

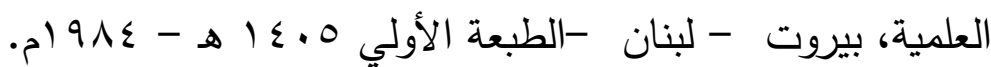
ه- إصــلاح الخلـل الواقـع فـي الجمـل لابـن الســيد البطليوسـي تحقيـق د// حمزة عبد الله النشرتي الرياض و و 9 أهـ - م. ج- الأعـلام تراجم لأشـهر الرجـال والنسـاء لخيـر الدين الزركلي، دار العلم للملايين، الطبعة الثالثة -بيروت (بدون تاريخ). V - الإفـادات والإنشـادات للشـاطبي تحقيـق د/ حمد أبـو الاجفـان، مؤسسـة

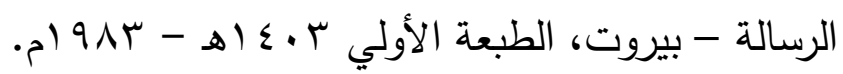

1- الاقتـراح في عـم أصـول النحـو للإمـام السـيوطي حقتهـ د/ أحمد سـليم

$$
\text { الحمصي، ود/ محمد أحمد قاسم } 911 \text { (م. }
$$

9-إنبـاه الـرواة علـي أنبـاه النحـاة للقفطـي تحقيـق حمح أبـو الفضـل إبـراهيم،

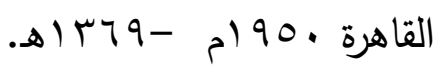

• ا- الإيضـاح في علل النحو للزجاجي تحقيق د/ مازن المبارك، طبعة دار

$$
\text { النفائس، بيروت - الطبعة الخامسة } 7 \text {. ع أه - } 9 \text { - (م. }
$$

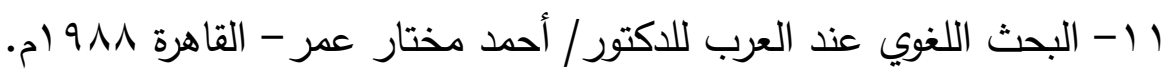

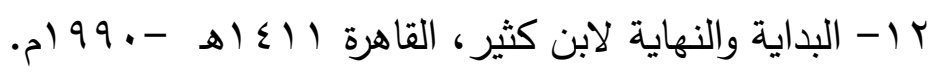

ب ا - برنامج المجاري تحقيق د/ عحم أبو الأجفان - دار الغرب الإسـلامي -

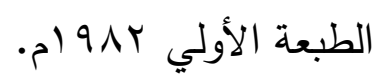

ع ا- بغيـة الوعـاة في طبقـات اللغـوينين والنحساة للسـيوطي تحقيـق: حمد أبـو

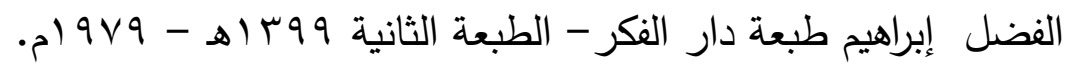

ه - تاريخ الأدب العربي لبروكلمـان - الجزه الأول - نقلـه إلبي العربية -

$$
\text { د/ عبد الحليم النجار - القاهرة - } 919 \text { ام. }
$$

7 ا - تاريخ التعليم في الأندلس للدكتور / حمد عبد الحميد عيسي- طبعة: دار

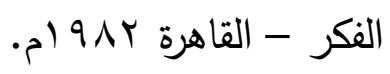


حوليت كليت اللغت العربيت بإيتاى البارود (العدد الثاني والثلاثون - المجلد الرابع)

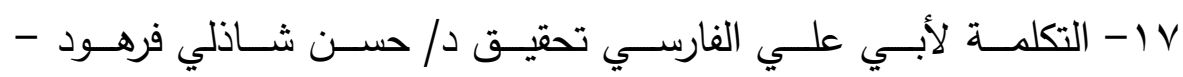

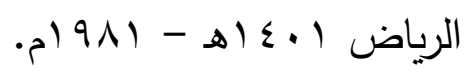

1 ا - الجمل للزجاجي اعتني بتصحيحة وشرح أبياته الشيخ / أبن أبي شنب،

الأسـتاذ بكليـة الآداب بـالجزائر ، مطبعـة: جـول كربونـل - الجزائرر -

$$
\text { . } 947
$$

9 1- خزانة الأدب للبغدادي تحقيق أ /عبد السلام هارون - القاهرة 919 ام

$$
\text { s) } \leqslant .9-
$$

• r- الدرر الكامنـة في أعيـان المائة الثامنـة لابـن حجر العسقلاني طبعة:

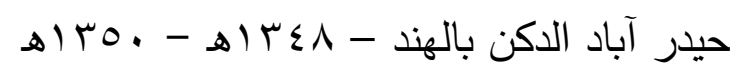

ا Y -الزجـاجي حياتـه وأثـاره ومذهبـه النحـوي مـن خـلال كتابــه الإيضــاح

للدكتور / مازن المبارك، طبعة دار الفكر -الطبعة الثانية ع . ع 1 هـ

$$
\text { -р) } 9 \wedge \varepsilon-
$$

r r -ثـجرة النـور الزكيـة في طبقـات المالكيـة لـحمد بـن حمح بـن مخلـوف المطبعــة السـلفية - دار الكتـب العربيـة، بيـروت، الطبعــة الأولـي

$$
\text { . } 1 \text { ( } 1 \text { \& }
$$

بr-شـذرات الذهب في أخبار مـن ذهب لابـن العمـاد الحنبلي ، القـاهرة -

$$
\text { . } 9 \text { ) } 9 \text { r }
$$

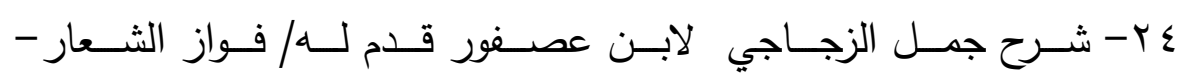

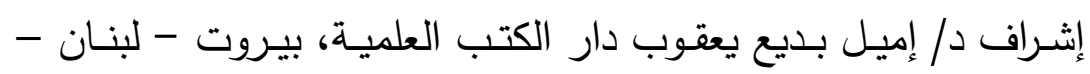

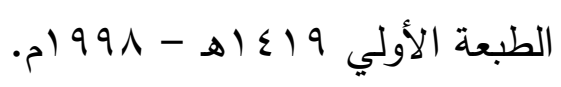

هץ - طبقـات النحوين واللغـوين للزبيدي تحقيق: حمد أبـو الفضـل إبراهيم -

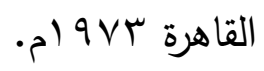

بr- غايـة النهايـة في طبقـات القـراء لابـن الجـوزي عنـي بنثـره المستشـرق

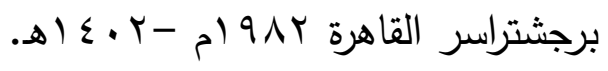




\section{دراسة موازنة بين منسجه الزجاجي وابن الفخار في تترح الجمل}

حوليت كليت اللغت العربيت بإيتاى البارود (العدد الثاني والثلاثون - المجلد الرابع) TV

$$
\text { . ) } 9 \wedge V-
$$

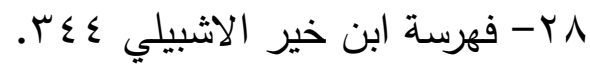

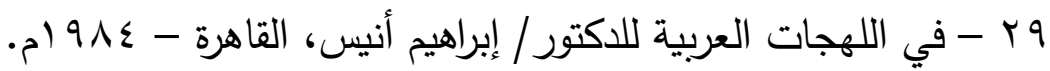

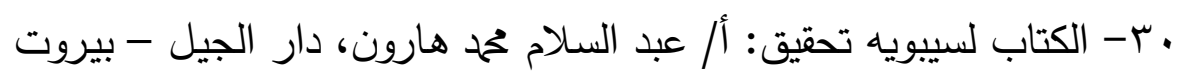

$$
\text { الطبعة الأولي (بدون تاريخ). }
$$

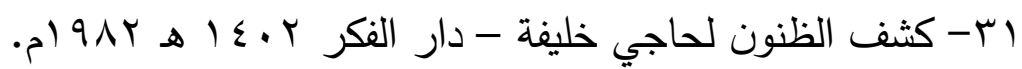

ץ - لسان العرب لابن منظور طبعة: دار الفكر - دار صسادر - بيروت -

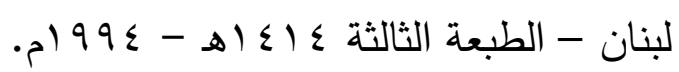

سب - اللمحة البدرية في الدولة النصرية للسان الدين بن الخطيب -منشورات

$$
\text { دار الأفاق الجديدة - الطبعة الثانية } 9 \text { V م. }
$$

ع - اللهجـات العربيـة في التـراث للـدكتور أحمـد علـم الـدين الجندي -

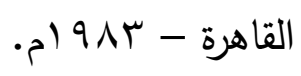

هب- المدارس النحوية للدكتور/شوقي ضيف - دار المعارف - القاهرة -

$$
\text { الطبعة السابعة. }
$$

جس- مـرآة الجنـان وعبـرة اليقظـان لليـافعي -حيـدر آبـاد الـدكن Vس اهـ -

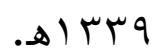

V V- المزهر في علوم اللغة للسيوطي، شرحه وضبطه خحم أحمد جاد المولي هـ بك، و حمح أبو الفضل، وعلي حمد البجاوي، بيروت 919 ام. ^ץ- معجم الأدباء لياقوت الحموي -القاهرة - بدون تاريخ. وس- معجم البلدان لياقوت الحموي - بيروت - بدون تاريخ.

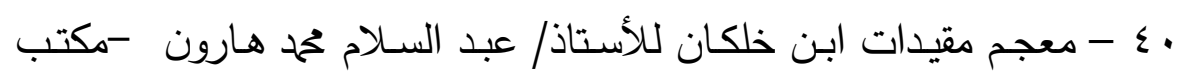

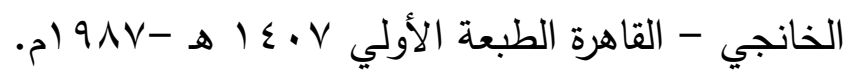

اء- معجـم المـؤلفين لعدـر رضـا كحالـة - دار إحيـاء التـراث العربـي -

$$
\text { بيروت (بدون طبعة وتاريخ). }
$$




\section{دراسة موازنة بين منسجه الزجاجي وابن الفخار فهي تترح الجمل}

حوليت كليت اللغت العربيت بإيتاى البارود (العدد الثاني والثلاثون - المجلد الرابع)

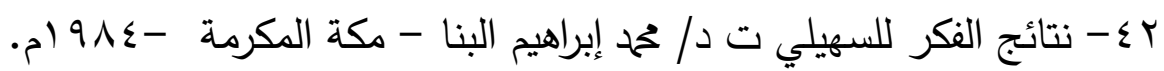
rع -النجوم الزاهرة لابن تغري بردي - القاهرة - بدون تاريخ.

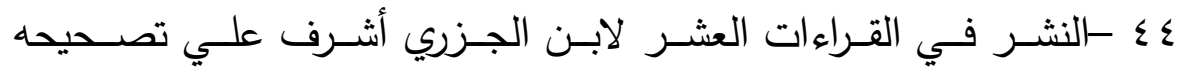

$$
\text { أ/ علي تحمد الضباع -القاهرة - بدون تاريخ. }
$$

0ـ- نفح الطيب من غصن الأندلس الرطيب للمقري - تحقيق د / إحسان

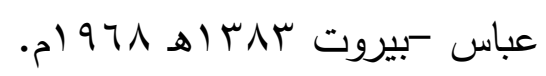

7ـ - همع الهوامع في شرح جمع الجوامع للسيوطي تحقيق أحمد شمس الدين

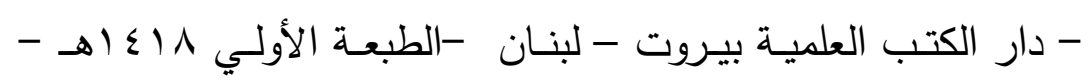

$$
\text { - }) 991
$$

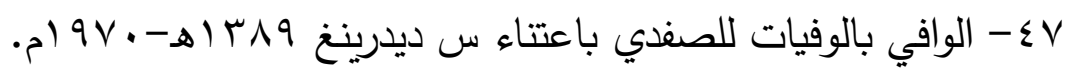

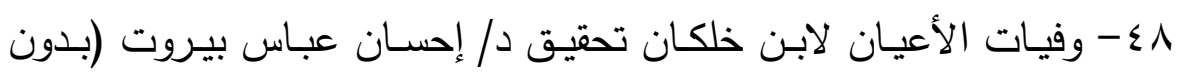

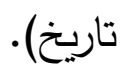


دراسة موازنة بين منسجي الزجاجي وابن الفخار في تترح الجمل

حوليت كليت اللغت العربيت بإيتاى البارود (العدد الثاني والثلاثون - المجلد الرابع)

رابعا : فهرب الموضوعات

\begin{tabular}{|c|c|}
\hline الصفحت & الموضوع \\
\hline צ سMr & المقدمة \\
\hline צrr" & التمهيد \\
\hline 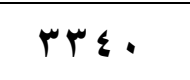 & الفصل الأول وفيه ثلاثة مباحث:- \\
\hline$r$ & المبحث الأول: ترجمة الزجاجي \\
\hline rrov & المبحث الثاني : التعريف بكتاب "الجمل" \\
\hline ruq & المبحث الثالث: ترجمة ابن الفخار \\
\hline rrAs & الفصل الثاني ويشمل:- \\
\hline rrAo & وتشمل الموزانة خمسة الفــار في "شـرح الجمـل" دراسـة موزانـة، \\
\hline rr人 & أولاً : من حيث بداية تأليف الكتابين \\
\hline rrAv & ثانيا: من حيث متن الكتابين. \\
\hline 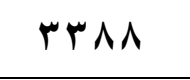 & ثالثا: من حيث عرض المادة العلمية في الكتابين. \\
\hline l & 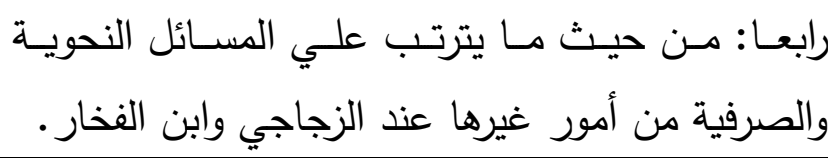 \\
\hline rqu & خامسـا: مـن حيث التعريفـات والحدود عند الزجـاجي \\
\hline rrqv & عند الزجاجي من حيث التفصيل في مسائل الخلاف النحوي \\
\hline$r \varepsilon \ldots$ & سابعا: من حيث التعليلات عند الزجاجي وابن الفخار \\
\hline$r \varepsilon \cdot r$ & ثامنا: من حيث الاختيارات عند الزجاجي وابن الفخار \\
\hline$r \leq . \wedge$ & 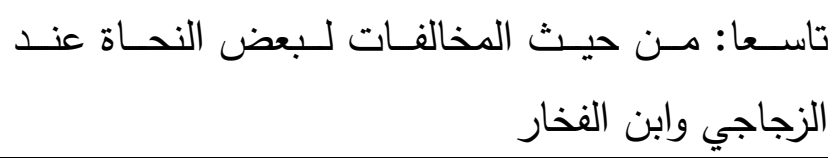 \\
\hline
\end{tabular}


دراسة موازنة بين منسجي الزجاجي وابن الفخار في تترح الجمل

حوليت كليت اللغت العربيت بإيتاى البارود (العدد الثاني والثلاثون - المجلد الرابع)

\begin{tabular}{|c|c|}
\hline r & عاشرا: من حيث أسلوب الزجاجي وابن الفخار • \\
\hline$r \varepsilon 17$ & وابن الفخار أو حضر : من حيث الحكايات التي وقعت للزجاجي \\
\hline$\Gamma \varepsilon \mid \Lambda$ & ثـاني عشـر : مـن حيـث الثـواهد عنـد الزجـاجي وابـن \\
\hline ه & 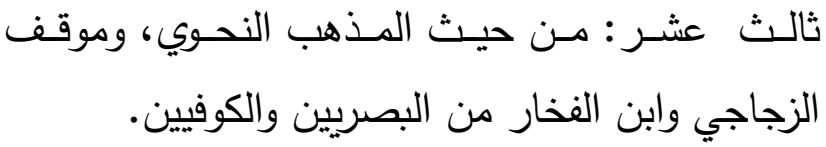 \\
\hline$r \varepsilon r \wedge$ & : مـن حيث اعتمـاد الزجـاجي وابن الفخـار \\
\hline$r \varepsilon r r$ & خامس عشر : من حيث موقف الزجاجي وابن الفخار \\
\hline & موقف ابن الفخار من الزجاجي (اعتراض ودفاع) \\
\hline$r \varepsilon \varepsilon Y$ & (اتفاق وافتراق) \\
\hline$\mu \varepsilon \varepsilon \varepsilon$ & 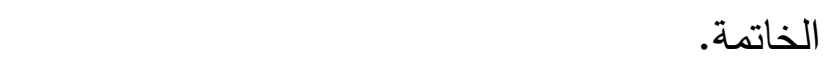 \\
\hline$r \varepsilon \varepsilon q$ & فهرس الآيات القرآنية \\
\hline$\mu \varepsilon \varepsilon \neg$ & فهرس الأحاديث النبوية الشريفة \\
\hline$r \varepsilon \varepsilon q$ & فهرس الأبيات الشعرية \\
\hline$r \varepsilon \varepsilon V$ & فهرس المراجع والمصادر \\
\hline$r \varepsilon \bullet r$ & فهرس الموضوعات \\
\hline
\end{tabular}

